\title{
A PROCESS FOR CONTAINMENT REMOVAL AND WASTE VOLUME REDUCTION TO REMEDIATE GROUNDWATER CONTAINING CERTAIN RADIONUCLIDES, TOXIC METALS AND ORGANHES EIVED
}

\section{Final Report}

Contract No. 02112415
JUN 291993

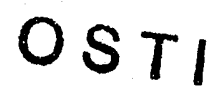

\author{
By \\ Leo P. Buckley, \\ Doug R.W. Killey, \\ Shiv Vijayan \\ and Pierre C.F. Wong
}

Prepared for

Office of Research and Development Technology Development, Environmental Restoration and Waste Management U.S. Department of Energy 1000 Independence Avenue Washington, DC 20585-0002

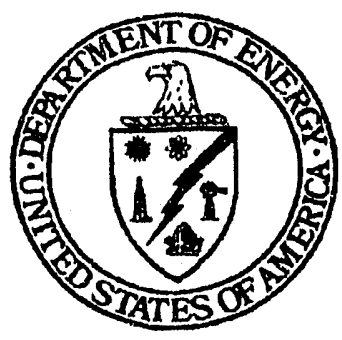

Research and Development Program Coordination Office Waste Management and Technology Development Chicago Field Office U.S. Department of Energy 9800 S. Cass Avenue Argonne, IL 60439

Research and Development Program Coordination Office

Chemical Technology Division, Argonne National Laboratory 9700 S. Cass Avenue, Argonne, IL 60439

under Prime Contract W-31-109-Eng-38 to the U.S. Department of Energy 


\section{DISCLAIMER}

This report was prepared as an account of work sponsored by an agency of the United States Government. Neither the United States Government nor any agency thereof, nor any of their employees, makes any warranty, express or implied, or assumes any legal liability or responsibility for the accuracy, completeness, or usefulness of any information, apparatus, product, or process disclosed, or represents that its use would not infringe privately owned rights. Reference herein to any specific commercial product, process, or service by trade name, trademark, manufacturer, or otherwise, does not necessarily constitute or imply its endorsement, recommendation, or favoring by the United States Government or any agency thereof. The views and opinions of authors expressed herein do not necessarily state or reflect those of the United States Government or any agency thereof.

Reproduced frein the best available copy.

Available to DOE and DOE contractors from the Office of Scientific and Technical Information P.O. Box 62

Oak Ridge, TN 37831

Prices available from (615) 576-8401

Available to the public from the National Technical Information Service

U.S. Department of Commerce

5285 Port Royal Road

Springfield, VA 22161 


\title{
A PROCESS FOR CONTAINMENT REMOVAL AND WASTE VOLUME REDUCTION TO REMEDIATE GROUNDWATER CONTAINING CERTAIN RADIONUCLIDES, TOXIC METALS AND ORGANICS
}

Final Report, Contract No. 02112415

\author{
By \\ Leo P. Buckley, \\ Doug R.W. Killey, \\ Shiv Vijayan \\ and Pierre C.F. Wong \\ Atomic Energy of Canada Limited \\ AECL Research \\ Chalk River Laboratories \\ Chalk River, Ontario, Canada KOJ $1 \mathrm{JO}$ \\ Phone: (613) 584-3311 \\ Fax: (613) 584-4024
}

September 1992

\section{Prepared for}

Office of Research and Development

Technology Development, Environmental Restoration and Waste Management U.S. Department of Energy 1000 Independence Avenue Washington, DC 20585-0002

Research and Development Program Coordination Office Waste Management and Technology Development, Chicago Field Office

U.S. Department of Energy 9800 S. Cass Avenue

Argonne, IL 60439

Research and Development Program Coordination Office Chemical Technology Division, Argonne National Laboratory 9700 S. Cass Avenue, Argonne, IL 60439-4837

under prime contract W-31-109-Eng-38 to the U.S. Department of Energy 


\section{PREFACE}

Currently available technology is not adequate to assess environmental contamination at Department of Energy (DOE) sites, take permanent remedial action, and eliminate or minimize the environmental impact of future operations. Technical resources to address these shortcomings exist within the DOE community and the private sector, but the involvement of the private sector in attaining permanent and cost-effective solutions has been limited.

During 1990, on behalf of DOE's Office of Technology Development, Argonne National Laboratory (ANL) conducted a competitive procurement of research and development projects addressing soil remediation, groundwater remediation, site characterization, and contaminant containment. Fifteen contracts were negotiated in these areas.

This report documents work performed as part of the Private Sector Research and Development Program sponsored by the DOE's Office of Technology Development within the Environmental Restoration and Waste Management Program. The research and development work described herein was conducted under contract to ANL.

On behalf of DOE and ANL, I wish to thank the performing contractor and especially the report authors for their cooperation and their contribution to development of new processes for characterization and remediation of DOE's environmental problems. We anticipate that the R\&D investment described here will be repaid many-fold in the application of better, faster, safer, and cheaper technologies.

Details of the procurement process and status reports for all 15 of the contractors performing under this program can be found in "Applied Research and Development Private Sector Accomplishments - Interim Report" (Report No. DOE/CH-9216) by Nicholas J. Beskid, Jas S. Devgun, Mitchell D. Erickson and Margaret M. Zielke.

Mitchell D. Erickson Contract Technical Representative Research and Development Program Coordination Office Chemical Technology Division Argonne National Laboratory Argonne, IL 60439-4837 
page

ABSTRACT $\ldots \ldots \ldots \ldots \ldots \ldots \ldots \ldots \ldots \ldots \ldots \ldots \ldots \ldots \ldots \ldots \ldots \ldots \ldots \ldots \ldots \ldots$

EXECUTIVE SUMMARY $\ldots \ldots \ldots \ldots \ldots \ldots \ldots \ldots \ldots \ldots \ldots \ldots$

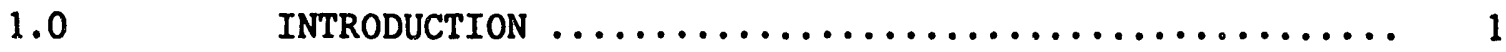

$2.0 \quad$ METHODOLOGY AND APPROACH $\ldots \ldots \ldots \ldots \ldots \ldots$

$2.1 \quad$ Facilities and Equipment .................... 2

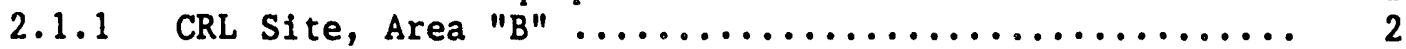

2.1.2 Process Demonstration Facility .................. 3

2.1 .3 Bench-Scale Apparatus ........................ 3

2.1 .4 Pilot-Scale Apparatus ........................ 4

$2.2 \quad$ Reagents and Supplies ...................... 5

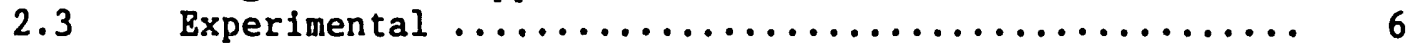

2.3 .1 Waste Influents .......................... 6

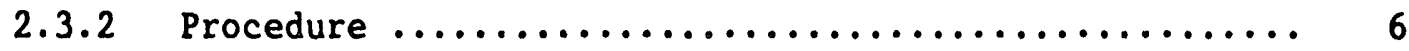

2.3.3 Process System Monitoring ...................... 9

2.3.4 Sampling and Analysis ........................ 9

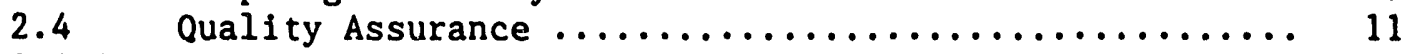

2.4.1 Chemical Analysis Errors ...................... 11

2.4 .2 Other Experimental Errors ..................... 11

RESULTS AND DISCUSSION ...................... 15

3.1 Bench-Scale Studies .......................... 15

3.1 .1 Simulated Waste Solutions ..................... 15

3.1.2 Contaminated Groundwater ..................... 17

3.1.3 Bench-Scale Soil Leaching and Leachate Treatment .... 17

3.2 Pilot-Scale Studies .......................... 19

3.2 .1 Simulated Solutions .......................... 19

3.2 .2 Groundwater ................................ 20

3.2.3 Groundwater Spiked With Contaminants ............... 20

3.2.4 Soil Leaching Results and Leachate Treatinent ........ 20

3.2.5 Dewatering of Dilute Suspensions ................ 23

3.3 Process Design ................................ 24

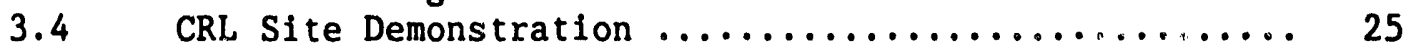

3.4.1 Single-Stage Chemical Treatment-Microfiltratior Process 25

3.4.2 Fixed-Bed Ion Exchange Column Tests ............... 25

4.1 Technology Development Evaluation ............. 27

4.1.1 Technology Capability ...................... 27

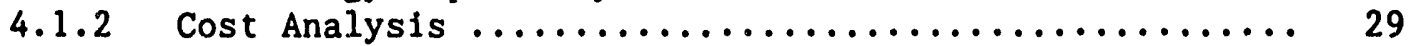

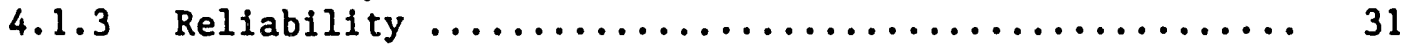

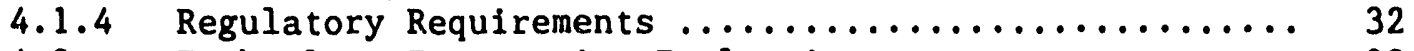

4.2 Technology Integration Evaluation $\ldots \ldots \ldots \ldots \ldots \ldots \ldots . \ldots \ldots$

4.2 .1 Need for Ancillary Technologies ............... 32

4.2 .2 Future Development $\ldots \ldots \ldots \ldots \ldots \ldots \ldots \ldots \ldots \ldots \ldots \ldots \ldots \ldots$ 
TABLE OF CONTENTS (contd...)

5.0

REPERENCES

5.1

Literature Cited

35

5.2

Publications

6.0

ACKNOWLEDGEMENTS

APPENDICES

Appendix A - Facilities and Equipment (Diagrams) ... Al

Appendix B - Performance Data from Bench-Scale Tests. Bl

Appendix C - Pilot-Scale Test Results ............ C1

Appendix D - Process Configuration and Costs ...... D1 
A project to remove groundwater contaminants by an improved treatment process was performed during 1990 October - 1992 March by Atomic Energy of Canada Limited for the United States Department of Energy, managed by Argonne National Laboratory. The goal was to generate high-quality effluent while minimizing secondary waste volume. Two effluent target levels, within an order of magnitude, or less than the U.S. Drinking Water Limit, were set to fudge the process effectiveness. The program employed mixed waste feeds containing cadmium, uranium, lead, Iron, calcium, strontium-85-90, cesium-137, benzene and trichloroethylene in simulated and actual groundwater and soil leachate solutions. A combination of process steps consisting of sequential chemical conditioning, cross-flow microfiltration and dewatering by low temperatureevaporation, or filter pressing were effective for the treatment of mixed waste having diverse physico-chemical properties. A simplified single-stage version of the process was implemented to treat ground and surface waters contaminated with strontium-90 at the Chalk River Laboratories site. Effluent targets and project goals were met successfully.

Overall test results revealed a three-step chemical treatment/microfiltration sequence combined with a final dewatering step is optimal. The key chemical treatment steps include: $\mathrm{pH}$ adjustment by lime addition combined with zeolite powder addition to precipitate, ion exchange, adsorb and scavenge most of the heavy metals along with iron, and some radionuclides and organics; sequential addition of natural zeolite ion exchange/adsorbent powder to remove radionuclides, residual heavy metals and some organic contaminants, and; sequential addition of powdered activated carbon with or without zeolite powder as a polishing step to remove organics and residual radionuclides. Process economics were assessed for treatment plants of 2 and $300 \mathrm{gpm}$ throughput capacities and compared with a conventional process. There are significant technical advantages and economic benefits to apply the chemical conditioning microfiltration process for site remediation applications. 
EXECUTIVE SUHMARY

\title{
A PROCESS FOR CONTAMINANT REMOVAL AND WASTE VOLUME REDUCTION TO REKEDIATE GROUNDWATER CONTAINING CERTAIN RADIONOCLIDES, TOXIC METALS AND ORGANICS
}

\author{
Leo P. Buckley, Doug R.W. Killey, Shiv Vijayan and Pierre C.F. Wong \\ Atomic Energy of Canada Limited, AECL Research \\ Chalk River Laboratories, Chalk River, Ontario, Canada KoJ 1Jo
}

\section{Scope}

A research and development project to remove groundwater contaminants by an improved ex-situ treatment process began in 1990 october as a cost-shared arrangement between Atomic Energy of Canada Limited (AECL) and the United States Department of Energy (USDOE), managed through Argonne National Laboratory. The project, divided into three phases, covered a period of eighteen months. The focus was to develop and demonstrate a process that removes different types of contaminants from simulated and actual groundwater and soil leachate solutions. The goal for process development was to generate high-quality effluent while minimizing secondary waste volume. Two target levels were considered for the quality of effluent generated by the process: within one order of magnitude of the U.S. Drinking Vater Limit, or less than the drinking water limit. The project also provided an opportunity to demonstrate the process on a site at AECL's Chalk River Laboratories (CRL).

\section{Approach}

The purification of aqueous waste solutions containing heavy metals, radionuclides and trace levels of organic contaminants can be achieved by a variety of methods. One such method involves the use of standard unit operations including precipitation, clarification, thickening, filter pressing of sludge, sand-bed filtration, fixed-bed ion exchange, granular activated carbon adsorption, evaporation and neutralization techniques. To manage the secondary effluents generated by the process, additional process steps such as sludge solidification/immobilization and organic oxidation/destruction must be considered. As the process is targeted to treat low levels of radioactivity and volatile organics, it is essential to minimize fugitive emissions and other uncontrollable losses. Processes based on standard unit operations are generally suited for fixed and centralized installations. They are not generally satisfactory for site remediation applications, where transportability and ease of operation are desirable.

Our proposed process involved purification of contaminated water by a sequential addition of chemicals and adsorption/ion exchange materials to remove the contaminants. Conditioning produced a polydisperse system of size-enlarged complexes of the contaminants in three distinct configurations: water-soluble metal complexes, insoluble metal precipitation complexes, and contaminant-bearing particles of ion exchange and adsorbent materials. The waste volume was reduced by separation of the polydisperse system by cross-flow microfiltration, followed by dewatering using lowtemperature evaporation, or filter pressing. The water produced as filtrate is discharged if it meets a specified target water quality, or else the filtrate is recycled until the target is achieved. 


\section{Experimental}

The experimental program focussed on achieving high contaminant removal efficiencies. A combination of process steps were used consisting of sequential chemical conditioning, microfiltration and dewatering by low-temperature evaporation and/or filter pressing. The experimental results were analyzed for the contaminant loading in the treated water stream and volume reduction factors. The key variables included: type and composition of waste influent to the process; precipitation conditions; type of ion exchange/adsorbent material, their concentration and treatment condition; type and concentration of non-contaminant metals; type and concentration of leaching agent for soll washing; and conditions to solidify secondary waste produced by the process.

Simulated waste solutions were prepared using high-purity chemicals in metallic chorides form. Groundwater samples were collected from observation wells located at the CRL site. The soil-wash leachate solution was produced by extracting contaminated soils collected from the CRL site. The soil-washing experiments were conducted in a rectangular bin of $6 \mathrm{~m}^{3}$ in volume, using 6.7 tonnes of contaminated soil and $0.015 \mathrm{M} \mathrm{FeCl}_{3}$ as the leachant. The test program evaluated the effectiveness of the leaching process in a dynamic system simulating field conditions.

The demonstration site at CRL is near a storage facility that received solid radioactive wastes over 30 years ago. The site is located on a small sand dune and features a sedimentary sequence of aeolian sands overlying glaciofluvial deposits and crystalline bedrock. The glaciofluvial sediments consist primarily of slightly silty sand till, with occasional zones of stratified sediments, most frequently sands, but also some silts. The site occupies a topographic high between two small drainage basins. There is insignificant surface runoff on the dune sands, but infiltration produces a groundwater divide that bisects the site. Although the bases of the trenches are above the water table, the absence of infiltration control allowed radionuclides to be leached from the wastes and transported through the underlying groundwater flow systems to adjacent surface waters. The dominant contaminant in the plume is strontium-90.

A summary of the different waste influents employed in the tests and their composition is given in Table 1.

The bench-scale screening testing was carried out in the Phase 1 and Phase 2 studies using standard batch and flow membrane cells from Amicon and Osmonics Corporations. The cells were fitted with a $5-\mathrm{cm}$ diameter flat-sheet microfiltration membrane of 0.2 $\mu m$ pore-size. The pilot-scale process testing was performed in Phase 3 of the project using a cross-flow microfiltration system (Model No. 62004, Memtec America) and was equipped with a $4 \mathrm{~m}^{2}$ surface area of $0.2 \mu \mathrm{m}$ pore-size hollow fibre polypropylene membranes. The final volume reduction of the dilute suspension generated by the microfiltration unit was effected using either a low-temperature evaporation system (Model No. APTU-025, Calfran International) or a filter press unit (Model No. STP, EPOC Water Inc.).

A detailed Quality Assurance Plan was implemented in the project, particularly for sampling and chemical analysis. The major sampling objective was to collect feed, filtrate and concentrate samples to assess the effectiveness of the separation methods in removing contaminants from aqueous solutions. Wherever possible, procedures for analyses were adopted from standard U.S. EPA methods. In-house methods were used to determine radionuclide concentrations. 


\section{Process Performance}

The overall process performance data are given in Table 2. The sequential chemical treatment, combined with microfiltration, removes different types of contaminants effectively. The removal of the majority of calcium ions as calcium carbonate is the key to achieving the target levels for radioactive strontium.

The secondary waste generated by the microfiltration process, subjected to further volume reduction ( 30 fold) by low-temperature evaporation, gave excellent quality overhead condensate, usually an order of magnitude less than the drinking water limit for contaminants. The use of the filter press gave a filtrate quality that was typically an order of magnitude greater than the drinking water limit, and consequently the filtrate was recycled through the microfiltration unit.

The soil leaching tests established that the passage of 5.5 pore volumes of $0.015 \mathrm{M}$ $\mathrm{PeCl}_{3}$ through 6.7 tonnes of contaminated soil removed between 84 and $87 \%$ of $\mathrm{Sr}-90$. The total removal of $\mathrm{Sr}-90$ determined by the leachate data was $235 \mathrm{MBq}$, which was within $5 \%$ of the $244 \mathrm{MBq}$ value provided by the pre- and post-leach soil analyses. Given the heterogeneity in the soils, the agreement between the data is excellent. In the soil leaching tests, peak concentrations of $37800 \mathrm{~Bq} \mathrm{Sr}-90 / \mathrm{L}$ in the leachate occurred after passage of two pore volumes, with leachant concentrations then levelling off.

The test results demonstrated the technical feasibility of the proposed process for the effective treatment of mixed waste having diverse physico-chemical properties. The use of $\mathrm{FeCl}_{3}$ as the leachant to extract strontium-90 from the contaminated soil showed a synergistic effect: excellent strontium-90 removals from the soll at low concentrations at room temperature; and effective in the removal of metal ions in the first step of the leachate treatment by coprecipitation and adsorption-scavenging. Experience gained from the test program suggests that through adequate optimization of key variables, including the type of ion exchange/adsorbent materials and reagent addition-solution conditioning time, high-quality effluent water can be achieved.

\section{Process Demonstration}

On the basis of the pilot-scale results, a simplified field-scale process flowsheet, consisting of one or two stages of sequential chemical treatment combined with microfiltration and a dewatering step, was constructed. The equipment was configured to remove strontium-90 in the presence of iron, calcium and other alkaline earth metals from ground and surface waters contaminated from the leaching waste at a site on the CRL property. The treatment facility, with a throughput capacity of $2 \mathrm{gpm}$, was housed in winterized "temporary" buildings located close to the groundwater collection well.

The results of the demonstration tests showed that contaminated groundwater containing strontium-90 at levels of 1500 to $5000 \mathrm{~Bq} / \mathrm{L}$ was treated effectively, to produce a filtrate quality of less than $10 \mathrm{~Bq} \mathrm{Sr}-90 / \mathrm{L}$, which met the current Canadian drinking water limit for strontium-90 (10 Bq/L) but not the U.S. drinking water limit $(0.35 \mathrm{~Bq} / \mathrm{L})$. The $\mathrm{Sr}-90$ concentration in soil leachates produced from contaminated soll leaching tests with ferric chloride solution were reduced from 15000 to 28000 $\mathrm{Bq} / \mathrm{L}$ to about $100 \mathrm{~Bq} / \mathrm{L}$ using a five-stage treatment. The soil leachate results suggest that multiple stages of chemical treatment combined with microfiltration will be necessary to provide a filtrate water quality of 1 to $10 \mathrm{~Bq} \mathrm{Sr}-90 / \mathrm{L}$, whereas a single-stage treatment was adequate for the treatment of contaminated groundwater. The high ionic strength leachates generated from soil leaching with ferric chloride 
showed poor strontium-90 removal efficlencies, suggesting that ion exchange materials other than natural zeolites may be needed for the deployment of the proposed process for such situations, or that better removal of interfering calcium ions be attempted.

We gathered additional data on the performance of fixed-bed ion exchange columns, for direct comparison with the chemical treatment-microfiltration process using the same feed. The same type of zeolite used in the microfiltration tests, but with a different mesh size $(-35 /+40$ mesh) in a fixed-bed column test, produced effluent concentrations of $50 \mathrm{~Bq} \mathrm{Sr}-90 / \mathrm{L}$ with the passage of 150 bed volumes of groundwater containing $3600 \mathrm{~Bq} \mathrm{Sr}-90 / \mathrm{L}$. A preliminary analysis of the microfiltration process' ability to provide the same effluent quality suggests that zeolite requirements will be half that needed for the fixed-bed column. Further tests are in progress to validate this analysis.

Bench-scale solidification tests were conducted with samples of the secondary waste slurry consisting of iron precipitate and zeolite powder. A waste form prepared with Portland cement ( 80 to $90 \%$ on dry weight basis) is a promising product for

storage/disposal. Leachate tests with the solidified product gave a leachate quality that was within an order of magnitude of the drinking water limit for the various immobilized contaminants. Routine treatment of contaminated ground and surface waters at the CRL site is in progress.

\section{Overall Process}

A schematic of the overall process is shown in Figure 1. The process includes sequential steps of chemical treatment and cross-flow membrane filtration, together with dewatering by evaporation or filter-pressing. For practical and economic considerations, it appears that dewatering by filter-pressing is the preferred route for applications involving large throughputs. However, for site demonstrations involving 1 to $2 \mathrm{gpm}$ waste influent throughputs, low-temperature evaporation equipment is suitable to minimize secondary waste volume.

The key chemical treatment steps are: 1) $\mathrm{pH}$ adjustment by lime addition combined with zeolite powder addition to precipitate, ion exchange, adsorb and scavenge most of the heavy metals along with iron, and some radionuclides and organics; 2) a sequential addition of a natural zeolite ion exchange/adsorbent powder to remove radionuclides, residual heavy metals and some organic contaminants; and 3 ) a sequential addition of powdered activated carbon with or without zeolite powder as a polishing step to remove organics and residual radionuclides.

The process has a number of advantages over conventional techniques. The combined action of precipitation, coprecipitation, adsorption and ion exchange, and cross-flow microfiltration, removes contaminants effectively into a concentrated suspension while generating quality effluent appropriate for discharge. There is a direct contact of contaminants with iron and other metal precipitates, powdered adsorbent and ion exchange materials. Powdered ion exchange/adsorbent materials provide high contaminant removal efficiencies and fast kinetic. Low-cost waste by-products of ior: exchange/adsorbent materials are employed. Cross-flow micrcfiltration with an air backwash system makes the process suitable for continuous operation and demands less space than conventional systems. The process reaches steady-state quickly and modular construction yields a large range of flow rate options and portability. The process is sufficiently generic to permit treatment of waste solutions containing a variety of radioactive and hazardous species. 


\section{Process Economics}

An assessment of the process economics was made by an estimation of the capital and operating costs of treatment plants of $2 \mathrm{gpm}$ and $300 \mathrm{gpm}$ throughput capacities. The installed costs were estimated at SUS 275000 for the $2 \mathrm{gpm}$ plant and at SUS 4 million for the $300 \mathrm{gpm}$ plant. The annual operating costs (excluding secondary waste disposal and capital recovery costs) were $\$ 368000$ and $\$ 4$ million for the 2 gpm and the $300 \mathrm{gpm}$ plant, respectively. Preliminary estimates annual costs for the secondary waste disposal amounted to about $\$ 50000$ (2 $\mathrm{gpm} \mathrm{plant}$ ) and $\$ 8$ million (300 gpm plant). It appears that the treatment plant of $2 \mathrm{gpm}$ throughput capacity may be a suitable choice for site demonstration and site remediation activities involving small-volume mixed wastes. The proposed process can be integrated effectively with other front-end and back-end conventional and emerging technologies.

A conventional process was configured with standard unit operations including precipitation, clarification, flocculation, thickening, fixed-bed ion exchange/adsorption with regeneration, and filter pressing. Because of the lack of performance data for the integrated system, reliable cost estimates could not be made for the reference plant. Consequently, a cost-benefit analysis for the proposed process with the reference process was :ot performed.

\section{Applicability}

The study revealed the potential of the proposed chemical conditioning of the waste influent combined with microfiltration for site remediation applications. The process can be used to treat groundwater, leachate from contaminated soil washing, surface and run-off waters contaminated with toxic metals, radionuclides and organics. The process can also be used to purify effluents from industrial processes such as discharges associated with smelting, mining and refining operations. Influent contaminants amenable to treatment are from a few $\mathrm{mg} / \mathrm{L}$ to hundreds of $\mathrm{mg} / \mathrm{L}$. By selecting appropriate conditions, contaminant removal efficiencies 99.9 percent or greater can be achieved. Depending on the specific application, the chemistry of the process can be modified easily to meet applicable standards for the effluent discharge.

\section{Contacts}

\section{Contractor Contacts:}

Leo P. Buckley

Atomic Energy of Canada Limited

Chalk River Laboratories

Chalk River, Ontario Canada KOJ 1JO

(613) 584-3311, Ext. 3646

Les A. Moschuk

Atomic Energy of Canada Limited

Chalk River Laboratories

Chalk River, Ontario, Canada kOJ 1 Jo

(613) 584-3311, Ext. 6057 
Table 1: Summary of Waste Influent Type and Composition

Type of Waste

Solution

(Influent)

Introduced

to the Process
Species and Concentration Range

\begin{tabular}{llllllllll}
\hline$[\mathrm{Cd}]$ & {$[\mathrm{Pb}]$} & {$[\mathrm{U}]$} & {$[\mathrm{Fe}]$} & {$[\mathrm{Ca}]$} & {$[\mathrm{Sr}-85]$} & {$[\mathrm{Sr}-90]$} & {$[\mathrm{Cs}-137]$} & {$[\mathrm{TCE}]$} & {$[\mathrm{Ben}]$}
\end{tabular}

(Concentration of Metals and Organics in $\mathrm{mg} / \mathrm{L}$; Radionuclides in $\mathrm{Bq} / \mathrm{L}$ )

Waste Influent to Process (note: TCE: trichloroethylene; Ben: benzene)

\begin{tabular}{|c|c|c|c|c|c|c|c|c|c|c|}
\hline 1. Simulated Waste & $\begin{array}{l}2 \text { to } \\
20\end{array}$ & $\begin{array}{l}10 \text { to } \\
200\end{array}$ & $\begin{array}{l}0.3 \\
\text { to } 5\end{array}$ & $\begin{array}{l}0 \text { to } \\
5 C\end{array}$ & $\begin{array}{l}0 \text { to } \\
50\end{array}$ & $\begin{array}{l}250 \text { to } \\
2500\end{array}$ & $\cdots$ & $\begin{array}{l}1000 \text { to } \\
10000\end{array}$ & $\begin{array}{l}2 \text { to } \\
13\end{array}$ & $\begin{array}{l}2 \text { to } \\
15\end{array}$ \\
\hline $\begin{array}{l}\text { 2. Groundwater/ } \\
\text { Surface water }\end{array}$ & --. & --- & -- & $\begin{array}{l}5 \text { to } \\
50\end{array}$ & $\begin{array}{l}50 \text { to } \\
75\end{array}$ & -- & $\begin{array}{l}1700 \text { to } \\
2100\end{array}$ & $--\cdot$ & $\cdots$ & $\cdots$ \\
\hline $\begin{array}{l}\text { 3. Spiked Ground } \\
\text { /Surface Water }\end{array}$ & $\begin{array}{l}2.5 \\
\text { to } 23\end{array}$ & $\begin{array}{l}9 \text { to } \\
10\end{array}$ & $\begin{array}{l}0 \text { to } \\
4.5\end{array}$ & $\begin{array}{l}55 \text { to } \\
70\end{array}$ & $\begin{array}{l}70 \text { to } \\
110\end{array}$ & $\begin{array}{l}950 \text { to } \\
2000\end{array}$ & 5400 & $\begin{array}{l}5700 \text { to } \\
10500\end{array}$ & $\begin{array}{l}2.3 \text { to } \\
2.6\end{array}$ & $\begin{array}{l}0.8 \text { to } \\
1.5\end{array}$ \\
\hline $\begin{array}{l}\text { 4. Soil-Wash } \\
\text { Leachate }\end{array}$ & -. & -.. & --- & $\begin{array}{l}70 \text { to } \\
5300\end{array}$ & $\begin{array}{l}80 \text { to } \\
130\end{array}$ & -- & $\begin{array}{l}15000 \text { to } \\
28000\end{array}$ & --- & $\cdots$ & -- \\
\hline
\end{tabular}

Table 2: Summary of Effluent (Filtrate) Composition Produced by the Process for Different Waste Influents Given in Table 1

Filtrate (Effluent)
Species and Concentration Range

\begin{tabular}{llllllllll}
\hline$[\mathrm{Cd}]$ & {$[\mathrm{Pb}]$} & {$[\mathrm{U}]$} & {$[\mathrm{Fe}]$} & {$[\mathrm{Ca}]$} & {$[\mathrm{Sr}-85]$} & {$[\mathrm{Sr}-90]$} & {$[\mathrm{Cs}-137]$} & {$[\mathrm{TCE}]$} & {$[\mathrm{Ben}]$}
\end{tabular}

(Concentration of Metals and Organics in mg/L; Concentration of Radionuclides in $\mathrm{Bq} / \mathrm{L}$ )

Filtrate Generated from Treating Waste Influent from Table 1:

\begin{tabular}{|c|c|c|c|c|c|c|c|c|c|c|}
\hline $\begin{array}{l}\text { Filtrate for } \\
\text { Influent } \# 1\end{array}$ & $\begin{array}{l}0.005 \\
\text { to } 0.9\end{array}$ & $\begin{array}{l}<0.02 \\
\text { to } 0.06\end{array}$ & $\begin{array}{l}<0.038 \\
\text { to } 0.06\end{array}$ & $\begin{array}{l}0.005 \\
\text { to } 0.02\end{array}$ & 55 & $\begin{array}{l}3.5 \text { to } \\
80\end{array}$ & $\cdots$ & $\begin{array}{l}3.5 \text { to } \\
18\end{array}$ & $\begin{array}{l}0.09 \\
\text { to } 0.15\end{array}$ & $\begin{array}{r}0.06 \\
\text { to } 0.08\end{array}$ \\
\hline $\begin{array}{l}\text { Filtrate for } \\
\text { Influent } \$ 2\end{array}$ & -- & --- & 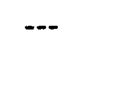 & $\begin{array}{l}0.01 \text { to } \\
0.02\end{array}$ & 16 & $\cdots$ & $\begin{array}{l}<3 \text { to } \\
10\end{array}$ & $\cdots$ & $\cdots$ & $-\cdots$ \\
\hline $\begin{array}{l}\text { Filtrate for } \\
\text { Influent } \# 3\end{array}$ & 0.003 & $<0.02$ & $<0.038$ & 0.007 & 5 to 6 & 30 & $\begin{array}{l}<8 \text { to } \\
80\end{array}$ & $\begin{array}{l}8 \text { to } \\
80\end{array}$ & 0.0012 & 0.003 \\
\hline $\begin{array}{l}\text { Filtrate for } \\
\text { Influent } \sharp 4\end{array}$ & --- & -- & -- & 0.009 & 54 & $\cdots$ & $\begin{array}{l}20 \text { to } \\
100\end{array}$ & ...- & -- & $\cdots$ \\
\hline
\end{tabular}




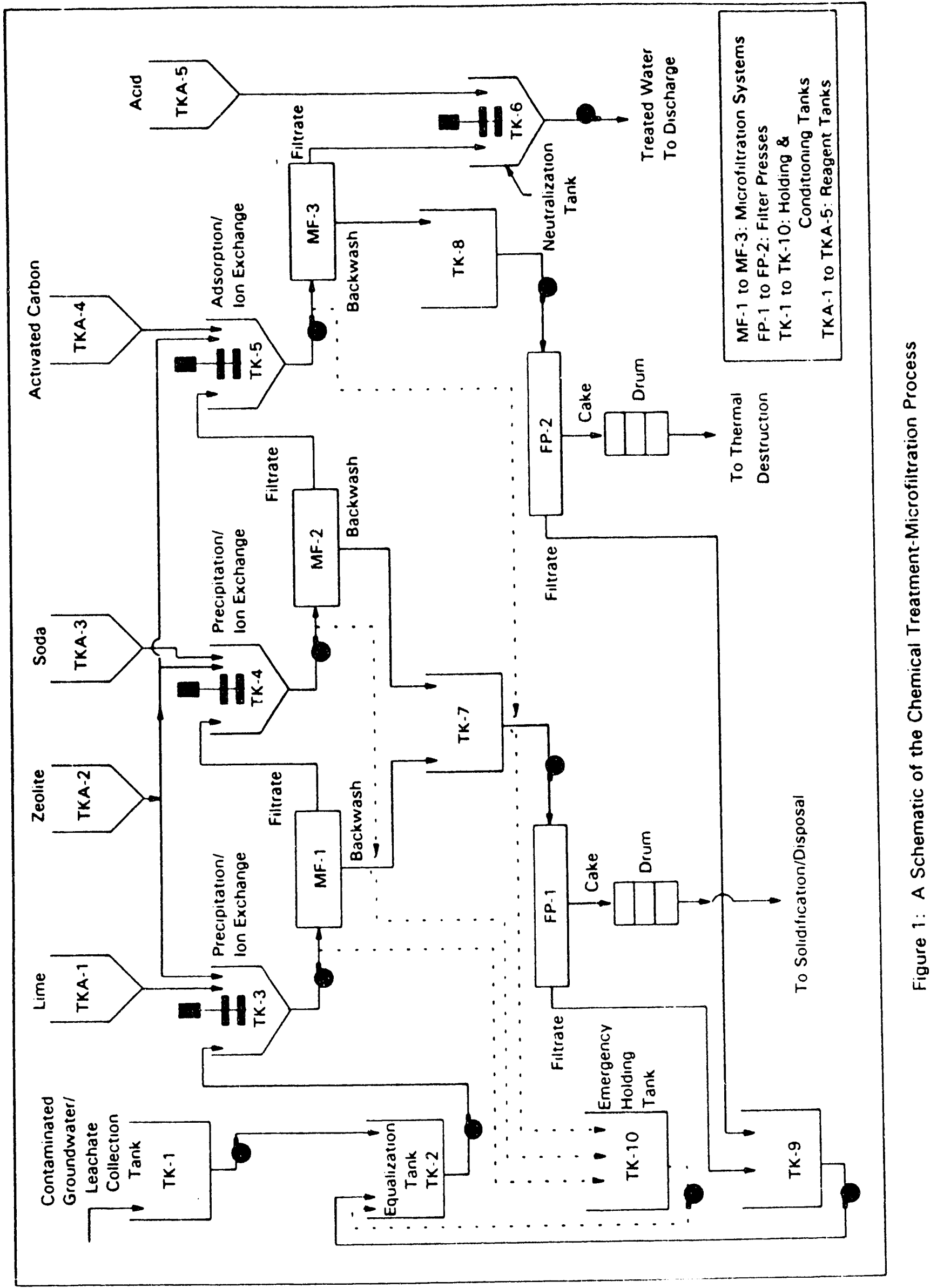

xii 


\subsection{INTRODUCTION}

The migration of radionuclides, toxic metals, inorganic ions and organic compounds from a source can lead to contamination of an aquifer, and subsequently can have far reaching consequences on the health of most affected members of the public. The transporting water containing the dissolved or dispersed species requires processing to produce a concentrated contaminant stream. Selectivity can be a major advantage by discriminating between the offending materials and those of no consequence since it reduces the waste volumes and perhaps the reagent costs. An ideal situation results in which only the contaminant is removed in the concentrating step, while allowing the reagents to be recycled. In actual situation, however, selective removal of contaminants is difficult because of interferences from non-hazardous species present in the waste. One of the major challenges of the development work is to get a suitable matih between those mechanisms promoting release from the soll and those utilized in the waste processing step.

A research and development project to remove contaminants by an ex-situ process began in October 1990. The duration of eighteen months was allocated to complete the project. The geal of the project was to determine how efficiently a combined process involving chemical treatment, cross-flow membrane separation and dewatering by low-temperature evaporation will extract representative radionuclides, toxic metals and trace levels of organics from different types of waste influents. The technology had to produce a high-quality effluent (filtrate) and provide a significantly reduced volume of secondary waste (concentrate) suited to immobilization and disposal. The program was also designed to provide an opportunity to demonstrate the process on a site at AECL's Chalk River Laboratories (CRL).

\subsection{METHODOLOGY AND APPROACH}

The research and development program was divided into three phases. To assist the program plan, a number of tasks had been identified for each phase of the project. Six major milestones were designed to monitor the progress of the profect as summarized below.

2) Complete bench-scale assessment for contaminant removal by the combined chemical treatment and membrane process using simulated groundwater.

3) Complete phase 1 report analysing results of bench-scale tests.

Phase 2

4) Complete bench-scale assessment for contaminant removal by the process scheme in milestone 3 using actual groundwater, and/or soil leachates.

Phase 3

5) Complete assessment of pilot-plant performance using simulated groundwater.

6) Complete final report detailing results of field evaluation of pilot-plant \& cost study of process. 
The process involves the withdrawal of contaminated water from an aquifer. The water is then conditioned by a sequential addition of chemicals and adsorption/ion exchange materials to remove the contaminants. The conditioning of the contaminated water produces a polydisperse system of size enlarged complexes of the contaminants in three distinct configurations: water soluble metal complexes, insoluble metal precipitation complexes and contaminant-bearing particles of ion exchange and adsorbent materials. The waste volume is reduced by dewatering of the polydisperse system by cross-flow microfiltration, followed by a final dewatering step using low-temperature evaporation, or filter pressing. The bulk of the water produced as filtrate is discharged if it meets a target water quality, or else the filtrate is recycled. Two levels were considered: efther within one order of magnitude of the U.S. Drinking Water Limit or less than the drinking water limit.

The following process target indicators were used to assess the effectiveness of the process.

(1) Produced Vater Quality Index (PWQI): This indicator determines the "quality" of the outgoing water stream from the process and denotes the effectiveness of the process. To evaluate the quality, we employ the U.S Drinking Water Limit [US, 1990] as our reference. PWQI is defined as the ratio of the concentration of contaminant in the treated water (filtrate) from the process to the concentration of the contaminant allowed for drinking water.

(2) Percent Contaminant Removal Efficiency (PCRE): The contaminant removal efficiency of the process as a percentage of the feed stream concentration is defined as a ratio of the product water quality index (PWOI) and the feed water quality index (FWOI):

$$
\text { PCRE }=[1-(\text { PWQI / FWQI })] \times 100,
$$

where, FWQI is equal to the ratio of the concentration of contaminant in the feed to that corresponding to the drinking water standard.

(3) Volume Reduction Factor (VRF) \& Concentration Factor (CF): The volume reduction factor is determined by the ratio: [Total feed volume] / [Pinal concentrate volume]. The concentration factor is similar to the volume reduction factor and is determined using a concentration value for specific chemical species in the feed and concentrate streams.

Because of the nature of the above targets, errors, especially in the contaminant chemical analysis, will have a direct bearing on the end results.

The U.S. Drinking Water Limits [EPA, 1990] for contaminants selected for the study are given in Table 2.1 .

\subsection{Facilities and Equipment}

\subsubsection{CRL Site, Area "B"}

The CRL site, Area "B" (Figure A.1, Appendix A), is a facility that has been used for the past 38 years for storage of solid radioactive wastes. The site is located on a small sand dune and features a sedimentary sequence of aeolian sands overlying glaciofluvial deposits and crystalline bedrock. The glaciofluvial sediments consist primarily of slightly silty sand till, with occasional zones of stratified sediments, most frequently sands, but also some silts. The site occupies a 
Table 2.1: Maximum Allowable Concentration for Selected Species in Drinking Hater under US EPA Regulations [EPA, 1990]

\begin{tabular}{|c|c|c|}
\hline Species & \multicolumn{2}{|c|}{ Maximum Allowable Conc. } \\
\hline $\begin{array}{l}\text { Benzene(Ben) } \\
\text { Cadmium (Cd) } \\
\text { Cesium-137 (Cs-137) } \\
\text { Iron ( } \mathrm{Fe}) \\
\text { Lead (Pb) } \\
\text { Strontium-85 (Sr-85) } \\
\text { Strontium-90 (Sr-90) } \\
\text { Trichloroethylene (TCE) } \\
\text { Uranium (U) }\end{array}$ & $\begin{array}{l}0.005 \\
0.01 \\
3.7 \\
0.3 \\
0.05 \\
150 \\
0.35 \\
0.005 \\
0.06\end{array}$ & $\begin{array}{l}\mathrm{mg} / \mathrm{L} \\
\mathrm{mg} / \mathrm{L} \\
\mathrm{Bq} / \mathrm{L} \\
\mathrm{mg} / \mathrm{L} \\
\mathrm{mg} / \mathrm{L} \\
\mathrm{Bq} / \mathrm{L} \\
\mathrm{Bq} / \mathrm{L} \\
\mathrm{mg} / \mathrm{L} \\
\mathrm{mg} / \mathrm{L}\end{array}$ \\
\hline
\end{tabular}

topographic high between two small drainage basins. There is insignificant surface runoff on the dune sands, but infiltration produces a groundwater divide that bisects the site from north-west to south-east. Although the bases of the trenches are above the water table, the absence of infiltration control allowed radionuclides to be leached from the wastes and transported through the underlying groundwater flow systems to adjacent surface waters. The dominant contaminant in the plume - is strontium-90. The contaminant plume also includes low concentrations of other radionuclides including $\mathrm{H}-3, \mathrm{Co}-60, \mathrm{Cs}-137$ and $\mathrm{Am}-241$. The $\mathrm{Sr}-90$ aquifer inventory is estimated to be about $7.22 \mathrm{TBq}$ (195 Ci). Maximum groundwater velocities in the area exceed 30 meters per year; minimum velocities are not well defined but estimated to be less than 1 meter per year. A plan view of the plume and the waste management area are shown in Figures A.1 and A.2 (Appendix A).

\subsubsection{Process Demonstration Facility}

The demonstration facility for the removal of strontium-90 from the surface/groundwater was located at the north-west side of the Area "B". The treatment facility, with a throughput capacity of $2 \mathrm{gpm}$, was housed in winterized "temporary" buildings located close to the groundwater collection well. A layout of the facility is shown in Figure A.3 (Appendix A). The contaminated water collection well consisted of a well tile-sump system containing a sump pump. Water was transferred to the treatment facility via buried PVC pipe line. The facility was placed about $4.5 \mathrm{~m}$ above the water level in the well. Based on August 1991 data, the well could deliver contaminated water at flow rates of up to about $30 \mathrm{~L} / \mathrm{min}$. The process equipment, tanks and other ancillary equipment were housed in temporary buildings. A trailer was placed beside the cabin for use as project office. Although the waste feed delivery was designed for continuous pump \& treat scheme, process demonstration was performed in a batch-feed processing mode of volumes of up to $2000 \mathrm{~L}$ per batch.

\subsubsection{Bench-Scale Apparatus}

\section{Microfiltration}

In the initial phases of the project, batch membrane cells were used. The cells had capacities of $50 \mathrm{~mL}$ and $200 \mathrm{~mL}$ and were purchased from Amicon. The batch cell consisted of a special membrane holder to allow for easy insertion or removal of 
the membrane without damage. The beakex-design allowed the sample to be poured in and out easily, and to provide maximum recovery and virtually no fluid loss. The stirring bar configuration facilitated efficient stirring of the sample. The cell configuration gave minimal liquid holdup volume. Flat-sheet polypropylene microfiltration membranes with an average pore diameter of $0.2 \mu \mathrm{m}$ were used to conduct screening studies.

\section{Bench-Scale Soll Leaching}

Bench-scale soil leaching was performed using $50 \mathrm{~mL}$ centrifugal tubes and $500 \mathrm{~mL}$ beakers depending on the size of leachate samples needed for process studies. The leaching vessels were closed with air-tight caps to prevent evaporation of water during long contact times. The vessels were mildly agitated at about $15 \mathrm{rpm}$ to provide intimate contact between the leachant and soil sample.

\subsubsection{Pilot-Scale Apparatus}

\section{Microfiltration System}

The Microcompact MEMCOR microfiltration system (model 620044 and 696906) was specially designed for the project and was purchased from Memtec America. A schematic flowsheet of the system is given in Figure A.4 (Appendix A). The system is a continuous cross-flow microfiltration unit and utilizes a gas backwash system to provide reliable operational performance. The heart of the unit is a set of 4 polypropylene hollow-fiber membrane cartridges with an average pore-size of $0.2 \mu \mathrm{m}$ and a total filter area of $4 \mathrm{~m}^{2}$. The unit was designed to provide nominal filtration rates of 2 to $3 \mathrm{gpm}$. By passing unfiltered feed solution over and around the hollow fiber, the suspended particles are built up on the outside of the fiber while clean filtrate passes through the membrane wall into the hollow centre of the fiber. The unfiltered portion of the feed-stream is returned to the feed tank in a more concentrated form. To maintain the processing rate, a gas backwash system is used. High pressure air is periodically forced from the centre of the fibers back across the membrane thereby expanding the fiber and allowing air to remove rejected material from the outside of the fiber. Generally, the time period between backwashes is set with a timer. Typically, a waste volume reduction factor of 20 was achieved.

\section{Dewatering Equipment}

\section{Low-Temperature Evaporation Unit}

The low-temperature evaporation unit was used to assess the effectiveness of dilute suspension streams produced by microfiltration. The evaporation was carried out between $5^{\circ} \mathrm{C}\left(-40^{\circ} \mathrm{F}\right)$ and $20^{\circ} \mathrm{C}\left(65^{\circ} \mathrm{F}\right)$. The unit was specially designed for the project to vary the evaporation temperature. The Calfran Unit APTU-025 is capable of producing about 25 US gallons per day of clean distillate from a feed containing waste water. A schematic of the unit is given in Figure A.5 (Appendix A). In the operation of the unit, the vacuum pump removes the air from the system causing the boiling point of the waste water in the range of 45 to $65 \circ \mathrm{F}$. As the waste water boils at this temperature, vapours for volatile components are generated leaving non-volatile impurities behind in the vaporizer vessel. The water vapour travels to the condenser and the condensed liquid water on the cold coil (cooled by a refrigerant) is periodically and automatically removed by a pump. The heat given up by the condensing water vapour evaporates the liquid refrigerant inside the coil. The gaseous refrigerant produced is then compressed. The heat contained 
In the gaseous refrigerant is now transferred back to the waste water in the vaporizer. This completes the energy reuse cycle for the gaseous refrigerant. The concentrate in the vaporizer is manually drained out.

\section{Filter Press System}

The filter press system, called the Exxpress unit (model STP), was purchased from EPOC Water, Inc. The principal component of the system is a woven filter cloth configured into a tubular array. The STP unit consists of a single tubular filter $(2.5 \mathrm{~cm}$. dia by $2.4 \mathrm{~m}$ long). A schematic of the skid mounted system is shown in Figure A.6 (Appendix A). The dewatering of dilute slurry occurs inside the tubular filter, called the module. The module is held by resin manifolds at each end to provide for flow entry and exit. When a dilute slurry is introduced into the module under pressure, the liquid permeates through the tube walls and the suspended solids are retained, forming a layer on the internal surface of the filter tube. The dewatering cycle is completed when the solids layer reaches a contrnlled thickness. The cake discharge (flush cycle) then commences by opening the module refect valve and traversing the module with squeeze rollers which removes the cake from the tube wall. The cake solids are transported out of the module by means of the flush liquid and are separated by a sleve-end separating screen. The module is effectively cleaned during each cake discharge cycle by the flush rollers and by the action of the flush liquid.

\section{Pilot-Scale Soil Leaching}

The soil-leaching equipment was of a rectangular configuration, constructed of 1.3 $\mathrm{cm}$ thick plate steel coated with epoxy paint and tapering slightly towards the bottom. The base of the apparatus was provided with a tile drain system consisting of three lengths of $7.5 \mathrm{~cm}$ ID perforated PVC drainage tile connected to a header. Clean gravel (2 to $3.5 \mathrm{~cm}$ diameter) was placed around and over the drainage tile, forming a bed $25 \mathrm{~cm}$ deep. This was in turn overlaid by Mirafi P50 felted polyester filter fabric, with a nominal $150 \mu \mathrm{m}$ pore size and $0.20 \mathrm{~cm} / \mathrm{s}$ permeability.

Figure A.7 is a schematic of the leachant feed and collection system used in the experiment. A centrifugal pump was used to deliver the leaching solution onto the surface of the sediments in the apparatus. A float-actuated switch maintained flooding of the sediments during the experiment. Drainage from the apparatus was transferred to a holding tank for processing in the treatment plant using a highcapacity peristaltic pump. A vent pipe tied into the drain line upstream of the pump ensured gravity flow conditions within the sediment. A sequential sampler (Sigmamotor Model 6201) was also placed into the drain line upstream of the peristaltic pump to collect $200 \mathrm{~mL}$ aliquots in separate bottles every 45 minutes. Rates of drainage from the apparatus were measured approximately every three hours by timing the filling of a calibrated $6 \mathrm{~L}$ flask.

\subsection{Reagents and Supplies}

All chemical reagents employed in the experimental program were of analytical grade. The ion exchange material was a natural zeolite from Steelhead Speciality Minerals. Two types of zeolites were used: one was TSM-140 D with a $-35 /+40$ mesh size and the second was a powdered $(-325 /+400$ mesh size) product, TSM-140 H. This product is known for its ion exchange properties, especially for cesium and divalent cations [McGregor, 1990]. The solid density and the bulk density of the zeolite were $1600 \mathrm{~kg} / \mathrm{m}^{3}$ and 720 to $1280 \mathrm{~kg} / \mathrm{m}^{3}$, respectively. The powdered ($325 /+400$ mesh size) activated carbon from Calgon Carbon Corporation (Type BPL) and from Darco G-60 were employed in the organic removal experiments. 


\subsection{Experimental}

\subsubsection{Waste Influents}

The waste influents used in the tests are summarized in Table 2.2.

Soil samples for bench-scale leaching tests were mainly drawn from the CRL's library of pre-existing soil core materials; when suitable archive material was unavailable, fresh samples were collected. Contaminated soil for the pilot-scale leaching test was taken from the CRL site, Area "B", just below the water table in a unit of interstratified sands and silts. Containinated soil (taken from below the water table) was placed in a second pile and allowed to drain for about 3 hours. The soil was then transferred to the soll-leaching apparatus, placed in lifts about $0.2 \mathrm{~m}$ thick, and manually spread and compacted. The soils were still very close to saturation, and fluidized with gentle agitation.

Groundwater samples for bench-scale treatability tests program were collected from observation wells fitted with intake screens. Polyethylene piezometers with fritted polyethylene intakes were used. For pilot-scale study, groundwater was pumped to the treatment facility from the collection well specially installed in Area "B". In all cases, at least three standing water volumes were pumped from the wells prior to sample collection. The standing water surface in the well was followed down to remove old standing water, followed by pumping at the bot tom of the well screen to remove any settled solids. Water sample handling, storage and data recording protocols followed those specifled above for soil sampling [see QA Plan, DOE, 1991].

Simulated waste solutions were prepared using high purity chemicals, dissolving them in distilled-deionized water at a pH value of less than or equal to 2 . The process tests involved mainly a chloride medium. The starting chemical compounds were high purity metal chlorides, except for strontium and uranium, in which case strontium nitrate and uranium oxide $\left(\mathrm{UO}_{3}\right)$ were used. In the case of organics, high purity benzene and trichloroethylene from the same source was employed. Distilleddelonized water was used to dissolve the chemicals at the desired stock solution concentration to prepare simulated waste feed solutions. Stock and feed sclutions containing organics were freshly-prepared before use. The test feed solution was sampled and analyzed for the actual contaminant concentration during each test.

\subsubsection{Procedure}

\section{Soil Leaching}

Bench-scale contaminated soil leaching tests were conducted to examine the most promising leachant that could be eventually employed for the decontamination of the Area "B" soil sediments. The leaching tests also provided leachate samples as waste feed for bench-scale process tests using chemical treatment followed by microfiltration.

A composite soll was made up from 10 of the most contaminated samples in the set and was subjected to sequential leaching (see Table B.8, Appendix B). The mean activity for strontium-90 in the contaminated soil samples was $119 \mathrm{~Bq} \cdot \mathrm{g}^{-1}$. For most of the bench-scale leaching tests, 2 gram subsamples were taken using a mechanical splitter, placed in $50 \mathrm{~mL}$ centrifuge tubes, and contacted with $20 \mathrm{~mL}$ of the leaching solution. During the contact period, the tubes were rotated at 15 $\mathrm{rpm}$. Samples were centrifuged to separate the solids and liquids, and a $10 \mathrm{~mL}$ 
Table 2.2: Summary of Waste Influent Type and Composition

Type of Waste

Solution

(Influent)

Introduced

to the Process
Species and Concentration Range

[Cd] [Pb] [U] [ $\mathrm{Fe}][\mathrm{Ca}][\mathrm{Sr}-85][\mathrm{Sr}-90[\mathrm{Cs}-137]$ [TCE] [Ben]

(Concentration of Metals and Organics in $\mathrm{mg} / \mathrm{L}$; Radionuclides in $\mathrm{Bq} / \mathrm{L}$ )

Waste Influent to Process (note: TCE: trichloroethylene; Ben: benzene)

$\begin{array}{clllllllll}\text { 1. Simulated Waste } 2 \text { to } & 10 \text { to } & 0.3 & 0 & 0 & \text { to } & 0 & \text { to } & 250 \\ 20 & 200 & \text { to } 5 & 50 & 50 & 2500 & -.- & 1000 \text { to } & 2 \text { to } & 2 \text { to }\end{array}$

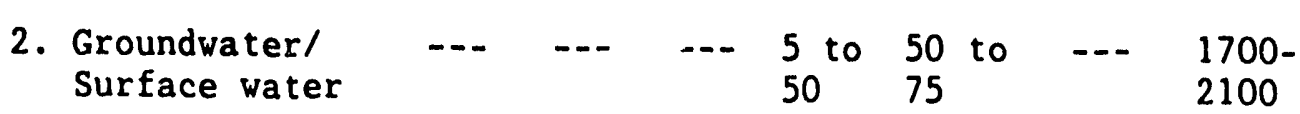

3. Spiked Ground 2.599 to 0 to 55 to 70 to 950 to 54005700 to 2.3 to 0.8 to /Surface Water to $2310 \quad \begin{array}{lllllllll}4.5 & 70 & 110 & 2000 & 10500 & 2.6 & 1.5\end{array}$

$\begin{array}{lllll}\text { 4. Soil-Wash } & -- & - & - & 70 \text { to } 80 \text { to } \\ \text { Leachate } & & & 5300130 & 15000 \\ & & & 28000\end{array}$

aliquot of the supernatant was analyzed for strontium-90. For bench-scale leachate treatment studies, larger amounts of soils were leached to provide sufficient volume of leachates. Typically, a $25 \mathrm{gram}$ soll sample was contacted with $250 \mathrm{~mL}$ of the leachant for a predetermined length of time. Following this, the suspension was filtered through a $0.45 \mu \mathrm{m}$ filter to obtain leachate feedstock.

The soll leaching study was performed using four different leachants at different leachant concentrations, leaching temperature and contact times. The leachants were selected on the basis of reasonable material costs for a larger-scale operation and for compatability with the subsequent treatment process for the separation of contaminants from the leachate. The four leachants were: sodium chloride, ferric chloride, cupferron (ammontum nitroso-beta-phenylhydroxylamine, a complexing agent) and sulphuric acid. To evaluate leachants, a composite was made of the 10 most active samples in the initial set. The leachant tests consisted of batch determinations using a fixed 10:1 solution:solid ratio and various contact times.

The pilot-scale soil leaching experiment was designed to provide information on effectiveness in a dynamic system under field conditions, and to provide feed solutions for pilot-scale process testing. Soll leaching was limited to one experiment using 6.7 metric tonnes of contaminated soil from the Area $B$ aquifer, with $0.015 \mathrm{M} \mathrm{FeCl}_{3}$ as the leachant. During the soil washing experiment, periodic effluent samples were analyzed for $\mathrm{pH}, \mathrm{Fe}, \mathrm{Cl}$, and $\mathrm{Sr}-90$. Cores of the soil were taken before and after treatment to provide independent information on the total quantity of $\mathrm{Sr}-90$ removed during the test, to measure the amount of residual activity, and to assess the uniformity of the treatment.

Contaminated soll for pllot-scale leaching test was taken from just below the water table in a unit of interstratified sands and silts (Figure A.2, Appendix A). Calculations of the total quantity of soll $\mathrm{Sr}-90$ before and after the leaching test 
were made by applying the concentration in each core section to a slice of soll in the bin that was the same thickness as the core section and that extended to adjacent bin walls and to the midpoint between one core location and the adjacent sampling site. All of these slices were summed to provide the total pre- and postleach $\mathrm{Sr}-90$ inventory.

\section{Chemical Treatment-Microfiltration}

For bench-scale tests, a waste feed solution of known $\mathrm{pH}$ and contaminant concentration was prepared and was fed to the membrane static cell containing the flat-sheet membrane. The feed pressure was maintained at about 10 psig by a nitrogen gas cylinder. The temperature of the operation was kept at room temperature $\left(23 \pm 2^{\circ} \mathrm{C}\right)$. During membrane filtration, the feed solution was stirred by a magnetic stirrer bar that is equipped as part of the cell. A fixed volume of the permeate solution was collected (e.g., $180 \mathrm{~mL}$ for the large cell and about $45 \mathrm{~mL}$ for the small cell), and the time taken to collect the fixed volume was also recorded. Samples of the starting feed solution and the fully mixed filtrate/permeate solution were taken at the end of the run and analyzed for contaminants.

In a typical pilot-scale operation involving the Memcor microfiltration unit, the conditioned waste feed was introduced to the microfiltration system via a prefilter/strainer $(100 \mu \mathrm{m})$ and feed pump. The conditioning of the feed solution includes chemical treatment involving solution $\mathrm{pH}$ adjustment, addition of adsorbent/ion exchange powder, etc. The pilot-scale experiments involving chemical treatment combined with microfiltration was performed using waste solution batch sizes of 400 to $2000 \mathrm{~L}$. Chemical conditioning of the waste was achieved with mechanical agitation in combination with closed-loop recirculation of the tank contents by means of a pump. The microfiltration of the conditioned waste solution was performed at a transmembrane pressure in the range of 7.5 to $15 \mathrm{kPa}$ [Transmembrane pressure $=$ (Feed pressure + Recirculation pressure/2) - Filtrate pressure]. By maintaining a constant filtration rate, the transmembrane pressure was essentially fixed for a given test. The microfiltration unit was operated in a 'concentration mode', in which the filtrate was continuously withdrawn while the cross-flow (concentrate stream) returned to the feed tank. All the experimental data reported were obtained at a filtration rate of $2 \mathrm{gpm}$.

\section{Low-Temperature Evaporation}

The low-temperature evaporation experiments were performed using two modes of operation: 1) continuous-feed, combined with continuous and batch evaporation mode and 2) batch-feed with batch evaporation mode. For the continuous-feed operation, the external feed tank was employed, and for batch-feed operation the evaporation vessel was used as the feed holding tank. For continuous-feed opera'tion the desired synthetic waste solution was prepared and charged to the external feed tank. Typically, a volume of up to 100 litres was used in the experiments. By deploying a vacuum lift, the vaporizer tank was filled to the predeteriained level with the feed solution. The feed was evaporated until the desired concentration was reached in the vaporizer tank. The batch-feed evaporation was identical to the continuous-feed mode of operation except that no external feed tank was employed. The starting waste feed was fed to the vaporizer tank (usually about 1411 tre) and evaporated until the desired volume reduction of the waste feed was achieved. 
During the evaporation tests, samples of the feed, concentrate and condensed overhead streams were taken at prespecifled time intervals to determine contaminant concentration. In addition, all the pressure and temperature readings were recorded as a function of evaporation time. In many tests, the different samples were also analyzed for electrical conductivity.

\section{P1lter Pressing}

The dewatering process consists of sequential cycles of loading the filter module followed by cake discharge/flushing of the cake solids to the separating screen. The load cycle was controlled by a timer mounted on the panel. At the conclusion of the load cycle, the cake discharge cycle commenced and the cake solids transported from the filter module by the flush liquid and collected on the separating screen. On completion of the flush cycle, the module was again put into its load cycle. Usually, waste feed suspensions containing 1 to $5 \mathrm{wt} . \%$ solids in $50 \mathrm{~L}$ batches were treated.

\subsubsection{Process System Monitoring}

The operating conditions were categorized into a) those which influence the process directly, and b) those with minimal effect on process performance. Certain varlables that influence the process, to a larger or a smaller extent, were maintained as fixed variables. The selection of the fixed variables was based on our previous experience. Process monitoring included a number of process variables as summarized in Table 2.3.

Typically, the pH of the feed solution was measured before the solution was chemically conditioned, and before and after it was processed by microfiltration, evaporation and by filter pressing. In bench-scale microfiltration tests, the filtrate rate was measured when samples were collected for contaminant analysis. In pilot-scale tests involving microfiltration, and dewatering by low-temperature evaporation and filter-pressing operations, the feed, concentrate and filtrate samples for analysis were collected via designated sample ports located on the flow lines. In mass balance experiments, the individual influent and effluent streams were collected in preweighed tanks for predetermined time periods and the mass of streams were determined using a calibrated weigh scale.

The filtration rate was measured in units of $\mathrm{mL} / \mathrm{s}$ or $\mathrm{L} / \mathrm{min}$, using precalibrated rotameters and by weighing the total mass of filtrate collected over a period of specified duration. This procedure was implemented routinely for every test. The evaporation rate (overhead condensate flow rate) was determined by measuring the condensed overhead stream volumetrically and/or gravimetrically for a specified duration.

\subsubsection{Sampling and Analysis}

\section{Sampling}

Samples of the waste feed and treated solutions were collected for contaminant analyses as detailed in the OA Plan. Samples were held in the laboratory refrigerator at $4^{\circ} \mathrm{C}$ for minimal time (one day to one week, depending on analytes) prior to shipment to Whiteshell Laboratories (AECL Research, Pinawa, Canada) for analysis. From the time of sampling, all analyses were completed within 14 days for organic analytes; within 180 days for radionuclides and inorganic analytes. 
Collection of the contaminated soll samples from the CRL site was achieved using hollow stem augers together with either split spoons or a piston core employing thin-wall aluminum tubing, and then transported in a cooler to the laboratory. In the laboratory, the samples were oven-dried before placing in sealed plastic bags for long-term storage at room temperature.

Table 2.3: Dependent and Independent Process Variables

Process System
Dependent Variable

(M: Measured; D: Determined)
Independent Variable (F: Fixed; V: Varied)

$\begin{array}{ll}\text { Waste Conditioning } & \text { - Turbidity (M) } \\ \text { by Chemical Treatment: } & \text { - Quantity of suspended } \\ \text { (a) Precipitation } & \text { particles (D) } \\ \text { (b) Ion exchange } & \\ \text { (c) Adsorption } & \end{array}$

Microfiltration

Low-Temperature Evaporation

- Filtrate rate (M)

- Concentration factor

- Filtrate quality (M) (concn. of species in

- Pressure drop (M) species (M)

- Contaminant removal efficiency, PCRE (D)

- Vaporization rate (M) the filtrate), \& Index

- Energy consumption (M)

- Amount of liquid backwashed as concentrate \& its concn. for different

- Volume reduction factor

- Concentration factor (D)

- Quality of condensate (M)

- Conc. of residue (M)

- Energy consumption (M)

- Water quality index, PWOI for the condensate stream (D)

(F)

- Temperature (F)

- Piltration time (V)

- Backwash time \& freq. (F)

- Cross-Flow rate (F)

- Conc. of solids in feed (V)

- Type of contaminant (V)

- Type of membrane cleaning agent (V)

- Pressure (F)

- Evaporator inlet/outlet temperature (F)

- Condenser inlet/outlet temperature ( $\mathrm{F}$ )

- Peed flowrate (V) for continuous external feed; Bixed (F) for batch feed

- Operation time (V)

- Total solids in feed (V)

- PIItration Pressure (F)

- Conc. of suspended solids in feed ( $V$ )

- Feed flow rate (F)

- Operation time (V)

- Type of contaminant and concentration ( $V$ )

- Temperature (F) 


\section{Sample Analysis}

Wherever possible, the procedures used to analyse samples were adopted from standard EPA methods and are summarized in Table 2.4. Some modifications were made to the EPA methods are detailed in the QA Project Plan [DOE, 1991]. In-house methods were used to analyze samples for radionuclides. The following is a summary of analyses that were not originally included in the OA Plan. These methods were adopted specifically for the contaminated soll-leaching study.

Concentrations of $\mathrm{Sr}-90$ in the effluent were measured by counting Cerenkov radiation from the samples, using a Canberra-Packard Model 1500 liquid scintillation counter. As with the soll samples, all aqueous solutions were stored for at least three weeks prior to analysis to allow $Y-90$ to grow into equilibrium with the Sr-90 parent. Backgrounds were measured by counting aliquots of the feed solution to the bin using the same geometry as that of the samples ( $10 \mathrm{~mL}$ in $22 \mathrm{~mL}$ borosilicate glass scintillation vials). Detection efficiencies were determined by spiking the samples with known amounts of $\mathrm{Sr}-90 / \mathrm{Y}-90$ (calibrated against NIST Standard Reference Material 4919-G, an aqueous solution of Sr-90/Y-90) after the initial activity determination was complete and then re-counting the samples.

\subsection{Quality Assurance}

Experimental procedures followed the quality assurance plan proposed at the beginning of the project. Analysis of the data and the experimental plans and procedures identified sources of error. Three types of errors were encountered in the experimental data: (1) errors resulting from chemical analysis, (2) sampling errors and (3) experimental errors due to improper control of critical variables (see Table 2.3).

\subsubsection{Chemical Analysis Errors}

All chemical analysis were performed following the QA Plan [DOE, 1991] and specific modifications to the $Q A$ Plan as summarized above. The instrumental errors were controlled and corrected by calibration procedures. Most personal errors were minimized by care and through control exercised by the Quality Control team. Method errors were determined by analysis of $s$ tandard samples, independent analysis, blank determinations and by varying sample sizes.

The precision was determined by replicate experiments performed under identical conditions. The precision corresponds to twice the standard deviation (2s) representing a $95 \%$ confidence level. It was found that the precision of analysis of a specific contaminant was dependent on the concentration of the species. Since a large number of measurements was carried out, correlations for each species using experimental data were developed to relate precision with contaminant concentration. The data used for the correlations were based on duplicate sample analysis. Because the samples involved contained a similar matrix of other species, the precision data were assumed to include all errors. A two-parameter power regression was used to obtain correlations of precision for each species (Table 2.5).

\subsubsection{Other Experimental Errors}

The important variables (see Table 2.3) in the experiments include: temperature, pressure, solution $\mathrm{pH}$, concentration of ion exchange and adsorbent materials, particle-size of adsorbent/ion exchange material, chemical conditioning time, 
Table 2.4: Standard Analytical Methods and Procedures

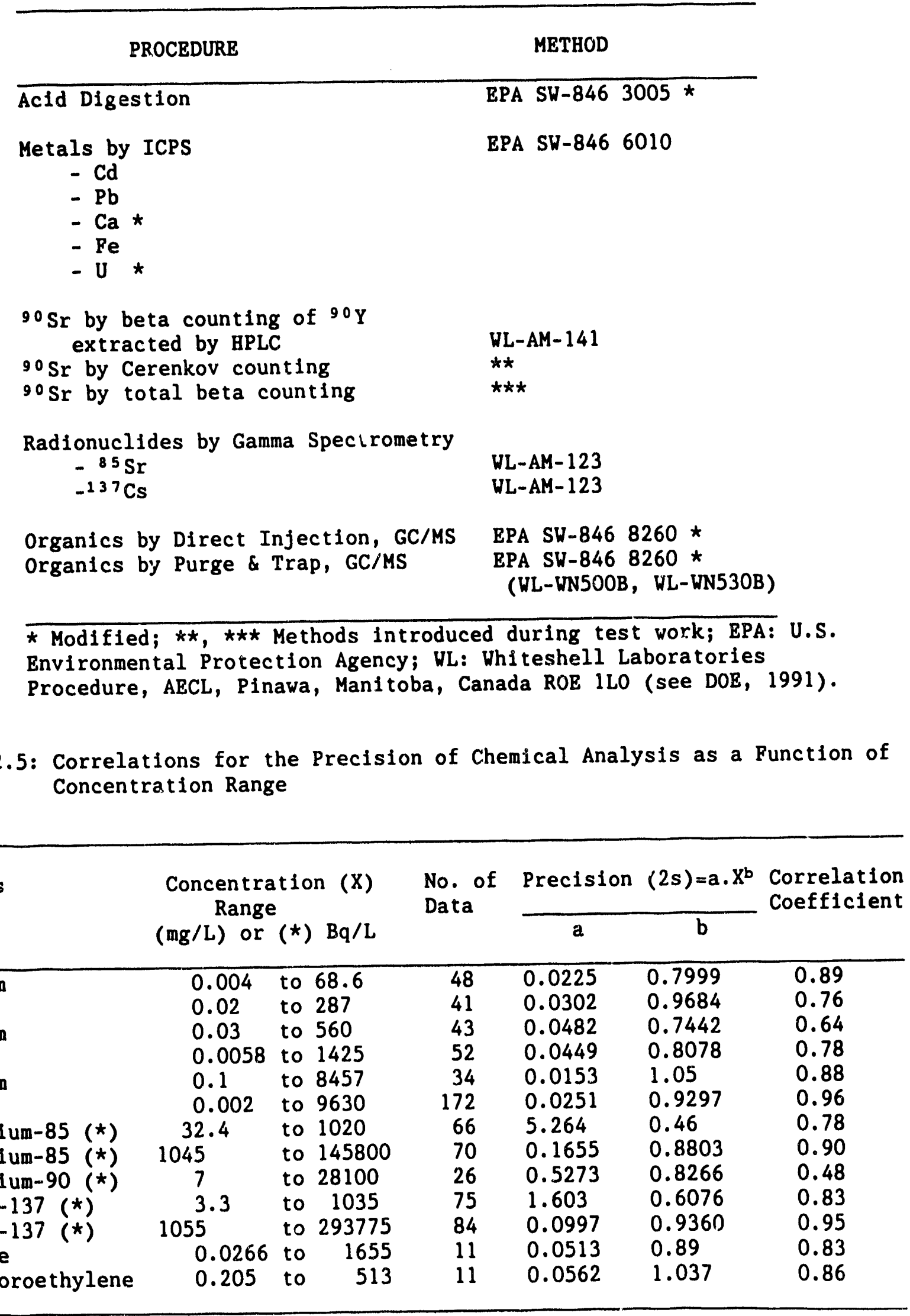


solution wixing intensity, and feed flow rate to process equipment. Adequate controls of the variables are esfential to minimize errors in the determination of the process target parameters. The process parameters are the quality of filtrate (from microfiltra:ion and filter pressing) and condensate (from low-temperature evaporation) streams, and concentration factor as a result of volume reduction in microfiltration, low-temperature evaporation and filter pressing. The system temperature affects the kinet ${ }^{2}$.cs and solubility of species in chemical precipitation, ion exchange and adsorption. However, as all chemical conditioning and filtration esperiments were performed at room temperature $\left(20\right.$ to $\left.23^{\circ} \mathrm{C}\right)$, the errors introduced as a result of the variations in temperature within the temperature range were determined to be insignificant. For low-temperature evaporation tests, the evaporator temperature was fixed within a narrow range of 6 to $10^{\circ} \mathrm{C}$ and hence was not expected to affect the condensate water quality, although the evapcration rate may be slightly different between each test. The icrofiltratior. and filter pressing of suspensions were carried out at room temperature. Variations of 1 to $2^{\circ} \mathrm{C}$ were not expected to influence significantly either the Eiltrition rate or solubility of contaminants durins filtration tests.

All chemical conditioning of the waste solutions were performed at ambient pressure. Por the filcration (microfiltration and filter pressing) tests, the same driving pressure was used in each test. Typically, the pressure variation was kept within $5 Z$ of the set point and this variation did not produce statistically measurable varlations to influence either the filtration rate, or the filtrate quality.

The solution $\mathrm{pH}$ was found to be critical for vaste conditioning by precipitation. This was particularly observed ror cadmium precipitation. In the bench-scale screening studies, most precipitation tests were perfoimed at solution pH values of 9.5 or 10 . Based on duplicate experiments, the average relative errors for the metais in the filtrate after microfiltration were $13 \%$ for cadmium, 0.27 for iron, whereas lead and uranium showed a deviation of $6 \%$. The average relative error includes errors arising from calibration of the pH meter, errors associated rith insufficlent mixing, conditioning time, etc. Errors solely due to soiution $\mathrm{pH}$ variations could not be decoupled for lack of sufficient data. For the pH range of 10.5 to 11 , no significant errors dus to $\mathrm{pH}$ variations were found. The solution $\mathrm{pH}$ was controlled withir $0.2 \mathrm{pH}$ unit values. The effect of small variations within a 0.2 pl unit value had negligible impact on contaminant removal efficiencies by precipitation, adsorption and ion exchange treatments.

The concentrations of adsorbent and ion exchange materials impacted significantly on the removis efficiencies of radionuclides and organics. Generally, the errors in the amcunc of addition of these materials resulted from the uncertainties in the precision of the veighing balance and in the solution volume measurement. The errors resulting from the amount of adsorbent added was larger for bench-scale tests than pilot-scale experiments. The estimated relative error for bench-scale tests was about $4 \overline{7}$ and that for pilot-scale tests was only $0.001 \%$.

The particle size of adsorbent/ion exchange material was not varied in the study. The median particle size was $20 \mu \mathrm{m}$ and all particles were less than $44 \mu \mathrm{m}$ in diameter. It was anticipated the distribution of particle sizes in each batch of adsorbent vould be slightly different. As the particle size effect was beyond the scope of the work package, errors associated with their variations from test to test were not examined. 
The conditioning time and intensity of mixing of reagents with the waste solution were important for the removal of contaminants by precipitation, ion exchange and by adsorption processes. For the data presented in this report, the conditioning time does not include times associated with filtration of suspensions. In reality, however, a finite time is involved in the filtration stage, and further transfer of contaminants may take place from the solution phase to the solid phase in the suspension. Since the conditioning time in the tank is much greater $(e . g .0 .5 \mathrm{~h})$ as compared with the instantaneous filtration time of a few minutes, it is expected that any error from the additional time, not included in the conditioning time, will not be significant enough to influence the contaminant removal results. The mixing of the solution was performed by bulk agitation with similar mixing intensities between experiments. The mixing intensity was not measured. Although micromixing is known to influence precipitation processes [Marcant and David, 1991], such effects were not expected to be dominant in the current experiments.

Filtration tesis had indicated that the quality of the filtrate was influenced by the filtrate and concentrate flow rates. For this reason, all tests were conducted at constant filtrate and concentrate flow rates. The uncertainty in the flow rate measurements of about $5 \%$ was not significant to impact the test results.

Sampling errors were kept to a minimum by following strictly the sampling protocols described in the QA Plan [DOE, 1991]. When deviations from the protocol occurred, a non-conformance was established by the analysts. Non-conformance samples were either abandoned, or if analyzed were not included in the final data compilation.

Prom an examination of the above errors, it was ascertained that uncertainties associated with the precision in chemical analysis were much greater than the combined errors resulting from other experimental sources. Consequently, only the analytical errors were considered in the data analysis. 


\subsection{RESULTS AND DISCUSSION}

\subsection{Bench-Scale Studies}

The goal of the experiments was to establish operating conditions that are controlled by the chemistry of the waste conditioning step which influenced the precipitation, ion exchange and adsorption processes. As a screening study, efforts were not directed toward optimization of the process variables to provide target quality effluent, rather, the test program focussed on the relative removal efficiencies of various contaminants. The quality of the product water stream was analyzed after using a combination of process steps consisting of chemical treatment and microfiltration. The key varlables included: 1) $\mathrm{pH}$ of the waste solution, 2) contaminant type and concentration, 3) non-contaminant impurities, 4) type of ion exchange/adsorbent materials and their concentration, and 5) solution conditioning time with chemical addition. The feed solution for the tests consisted of simulated waste solutions (containing cadmium, lead, uranium, strontium-85, cesium-137, benzene and trichloroethylene, iron and calcium), ground/surface waters (containing strontium-90, calcium and iron), groundwater spiked with synthetic contaminants, and soll leachate solutions (bearing strontium90, iron, calcium and anionics including chloride, carbonate and sulphate), produced from contaminated soll leaching by selected leachants.

In this section, results are discussed to support the selection of a process configuration for subsequent pilot-scale experiments.

\subsubsection{Simulated Waste Solutions}

Based on previously reported information [Peters et al., 1985], a solution pH value in the range of 9.5 to 11 achieved precipitation or heavy metals by caustic soda. The metals precipitated and separated by microfiltration included: cadmium, lead, uranium and iron. With this precipitation scheme, the radiostrontium and cesium, along with metal impurities such as calcium were essentially left unprecipitated in solution. Generally, these species can not be precipitated and extracted with solid-liquid separation. Consequently, the solution containing these species, after removal of the precipitated metals, was conditioned with zeolite powder to achieve radionuclide removal by an adsorption/ion exchange mechanism. Data given in Table B.l (Appendix B) demonstrate that at a solution $\mathrm{pH}$ value of 9.5 , a twostep chemical treatment-microfiltration process removes effectively the metals and strontium-85 below the drinking water limit (DWL). The absolute concentration of strontium-85 was still about $56 \mathrm{~Bq} / \mathrm{L}$. This level is still two orders of magnitude greater than the allowed limit for the normal encountered strontium- 90 isotope whose DWL value is $0.35 \mathrm{~Bq} / \mathrm{L}$. For cesium-137, although the removal efficiency was $99.4 \%$, the filtrate quality was two orders of magnitude greater than the DWL.

The lack of adequate removal of cesium-137 suggested that other process variables had to be altered. The obvious two most important variables are conditioning time for ion exchange and the amount of ion exchange material added. After performing a large number of screening trials, it was discovered, as shown in Table B.2, that cesium-137 can be reduced to drinking water levels by a staged addition of small amounts of the zeolite powder while keeping to shorter conditioning times. In this specified experiment no other contaminants were added to the feed. It was observed that longer conditioning time leads to 'self elution' of cesium as the concentration of cesium was reduced to within an order of magnitude of the DWL. 
The removal of strontium isotope ( $\mathrm{Sr}-85$ or $\mathrm{Sr}-90)$ is further complicated by the presence of calcium. Similar to barium-radium chemistry, the strontium-calcium physico-chemical properties are almost identical under precipitation, ion exchange and adsorption conditions. In practical situations, the waste solution is expected to have calcium and magnesium levels several orders of magnitude greater than radiostrontium concentrations. With the mismatch in the concentrations between calcium and strontium, together with the stringent standards for strontium-90 discharge levels (whether it be the drinking water limit of $0.35 \mathrm{~Bq} / \mathrm{L}$, or any other discharge limit), the radiostrontium removal is a challenge by itself, let alone other contaminants. Results given in Tables B.3 and B. 4 in Appendix B show the adverse effect of calcium on the removal efficiencies of strontium by zeolite ion exchange. For a similar ion exchange conditioning time, a calcium containing waste solution ( $45 \mathrm{mg} / \mathrm{L}$ ) with about one-half the concentration of strontium-85 as compared with a non-calcium waste, required three times the amount of zeolite to produce a filtrate quality that was still twenty times the DWL.

Because of the severe effect of calcium on radioactive strontium removal efficiency, the challenge was to remove calcium prior to strontium removal. The well-established lime-soda process for hardness removal applications [BETZ, 1980] was adopted. It was realized that there was much to be gained by introducing this scheme. For example, the use of high-cost caustic soda was replaced by the lowcost lime as calcium hydroxide. However, the excess calcium introduced would have to be removed as relatively insoluble calcium carbonate precipitate (in distilled water at room temperature, $\mathrm{CaCO}_{3}$ dissolves to the extent of about 15 to $20 \mathrm{mg} / \mathrm{L}$ ) by the addition of soda $\left(\mathrm{Na}_{2} \mathrm{CO}_{3}\right)$. A number of ways of performing the additions of lime, soda and zeolite in two main process steps were examined. An example is given in Table B.5 (Appendix B). The results demonstrate that the modified twostep process performs effectively to reduce heavy metals, iron, calcium and strontium-85 in the treated water to levels much lower than the DWL for the corresponding species. It is important to note that as uranium forms soluble carbonates, there was a need to split the carbonate addition stage from the lime addition stage. In Table B.5 the cesium concentrations reported appears to increase from Stage 1 to Stage 2. Within the accuracy of the analytical results, 1.e. $95 \%$ confidence interval, the cesium concentrations could be the same value at the levels given in Table B.5.

The effectiveness of powdered carbon addition on the removal of volatiles such as ben. and trichloroethylene was examined. An example of the test results is given in Table B.6. The results suggested that small amounts of volatile organics present in the waste can be removed to produce effluent containing organics within an order of magnitude of the DWL. Although the organic removal step need not be limited to a carbon-based scheme, a condition step involving a powdered adsorbent material combined with microfiltration should be adequate to remove small amounts of organics from the waste solution.

Bench-scale tests using simulated waste solutions suggested that through further optimization of key process variables (e.g., chemical conditioning time, type and concentrations of powdered adsorbent and ion exchange materials), it is possible to configure a three-step chemical treatment-microfiltration process. Such a process scheme would remove heavy metals, radionuclides and organics, and non-contaminant metal impurities, reduce the volume of the waste, and produce an effluent that is lower, or within an order of magnitude of the drinking water limit for contaminants governed under U.S. regulations. 


\subsubsection{Contaminated Groundwater}

The CRL site, Area "B", groundwater contained between 3000 and $4.500 \mathrm{~Bq} \mathrm{Sr-90/L}$ and trace levels cadmium, lead and uranium. Tritium levels varied from about $5000 \mathrm{~Bq} / \mathrm{L}$ to about $30000 \mathrm{~Bq} / \mathrm{L}$. Calcium and iron were present each at about $50 \mathrm{mg} / \mathrm{L}$. Analysis for anions revealed the presence of 100 to $120 \mathrm{mg} / \mathrm{L}$ carbonate. The natural $\mathrm{pH}$ of the water was between 6 and 6.5 .

To remove strontium-90 from the groundwater which contained iron, calcium and strontium-90, variations of the treatment routes obtained from simulated waste studies (section 3.1.1) were examined. The waste system being a relatively simple one, a single-step chemical treatment process combined with microfiltration was tested with additions of caustic, soda and zeolite powder. The reason for "two addition of zeolite" is to reduce the conditioning time. When the second batch of zeolite is added sequentially, the kinetic of adsorption increases because the calcium and strontium-90 iors are easier to access the exchange sites at the particle surface and independent of diffusion. The results presented in Table B.7 (Appendix B) show the capability of the process to remove trace heavy metal contaminants to well below the drinking water limit (DWL). Iron and calcium were reduced from about $50 \mathrm{mg} / \mathrm{L}$ each to $0.04 \mathrm{mg} / \mathrm{L}$ and $3.2 \mathrm{mg} / \mathrm{L}$, respectively. The removal efficiency for $\mathrm{Sr}-90$ was $97.8 \%$, but the filtrate water quality was about 200 times the DWL. However, a further conditioning of the filtrate with more zeolite powder, followed by a second microfiltration step reduced the $\mathrm{Sr}-90$ level to below $1 \mathrm{~Bq} / \mathrm{L}$, corresponding to the analytical detection limit for the sample matrix.

The bulk of the strontium was reduced easily by adequate sequencing of chemical addition. However, reduction below, say $100 \mathrm{~Bq} \mathrm{Sr}-90 / \mathrm{L}$, requires either a second treatment step, or more powerful ion exchange material than the natural zeolite employed in this study. The type of analysis technique and matrix effects had a direct impact on the detection limit. Among the analysis techniques employed for Sr-90, the wet extraction of yttrium-90 followed by beta counting provided the lowest detection reported by the quality assurance procedure as $<0.8$ or $<2$ to $<1$ $\mathrm{Bq} / \mathrm{L}$, depending on the sample matrix. These detection limits represent 2.2 to 5.7 times the drinking water limit.

\subsubsection{Bench-Scale Soil Leaching and Leachate Treatment}

The approach consisted of: 1) determination of the activity of contaminated soil samples from the CRL site, Area "B", 2) sequential leach tests to evaluate distribution of $\mathrm{Sr}-90$ in the soil, 3) leachant selection by soll-leach tests and 4) leachate treatment tests to remove $\mathrm{Sr}-90$ by a two-stage chemical conditioning of the leachate solutions combined with microfiltration using membrane cells.

\subsubsection{CRL Area "B" Soil Activity and Sequential Soil Leaching}

To characterize the nature of strontium-90 retention in the soll, aliquots of twenty five soil samples (collected from various locations beneath and down gradient of the soil trenches) were subjected to sequential leaching. Sequential leaching consisted of three principal stages. The leaching parameters are summarized in Table B.8 (Appendix B).

The leaching sequence provided discrimination between strontium- 90 sorbed by ior exchange and by chemisorption to amorphous and crystalline iron oxyhydroxides, with 
residual activity considered to be "fixed". Initial strontium-90 concentrations ranged from 40 to $400 \mathrm{~Bq} \cdot \mathrm{g}^{-1}$. The weighted average mixed soil activity was $119 \mathrm{~Bq}$ $\mathrm{Sr}-90 / \mathrm{g}$, while the measured bulk sample activity was $109 \mathrm{~Bq} \mathrm{Sr}-90 / \mathrm{g}(\sigma=4.25)$.

The results show that between 33 and $91 \%$ of sorbed Sr-90 was released during the ion exchange equilibration. The mean ion-exchange removal for the 25 samples was 72\%. The removal of amorphous Fe-oxides also removed between 0 and 28\%, the mean value being $13 \%$, of the initial quantity of $\mathrm{Sr}-90$, and subsequent treatment to dissolve crystalline Fe-oxides removed from 0 to $12 \%$ (mean $1 \%$ ) of the radiostrontium. At the end of the leach sequence, the soils on average retained about $15 \%$ of their initial amount of $\mathrm{Sr}-90$. It should be noted that "fixed" may not be truly immobile. Over $95 \%$ of the sorbed $\mathrm{Sr}-90$ can be extracted using hot aqua regia.

\subsubsection{Selection of Leachant and Extraction of Contaminants from Soil Samples}

Leaching solutions were selected on the basis of reasonable material costs for a large-scale operation and for compatibility with the treatment plant. The leach test results are shown in Figure B.1 (Appendix B). Among the leachants studied, dilute ferric chloride solutions in the concentration range of $0.01 \mathrm{~mol} / \mathrm{L}$ to $0.1 \mathrm{~mol} / \mathrm{L}$ showed excellent extraction of strontium-90 from Area "B" contaminated soils. Possible reasons for its effectiveness for strontium removal include: a) the higher valency effect of iron, thus requiring less concentration as compared with the monovalent $\mathrm{NaCl}$, b) the oxidizing nature of $\mathrm{FeCl}_{3}$ and c) the possible reduction of the electrical double-layer because of the valency effect, providing easy penetration of the leachant anion (in this case the chloride ions) into the soll particle to react with strontium. The leachates produced by contaminated soll washing contained over two to three times the amount of strontium-90 ( $10,000 \mathrm{~Bq} / \mathrm{L})$ as compared with the groundwater from CRL Area "B" ( 3000 to $4500 \mathrm{~Bq} / \mathrm{L}$ ).

\subsubsection{Strontium-90 Removal by Twc-Stage Chemical Treatment-Microfiltration}

The leachate solutions were subjected to a two-step chemical treatment combined with microfiltration treatment. The chemical treatment consisted: 1) feed solution $\mathrm{pH}$ adjustment to precipitate metals and 2) the addition of powdered zeolite to remove strontium-90. Removal efficiencies for strontium, calcium and iron, together with the filtrate and feed water quality values are summarized in Table B.9 (Appendix B).

The strontium-90 removal efficiency by the combined precipitation-microfiltration and ion exchange-microfiltration is in the range of $92 \%$ to $99.9 \%$ for the $\mathrm{FeCl}_{3}$ and $10^{-3} \mathrm{M}$ cubferron leachate feeds. The removal efficiency drops to about $60 \%$ for the $10^{-2} \mathrm{M}$ cupferron and sulphuric acid leachate feeds. In the two-step process, the majority of strontium removal is believed to take place through an ion exchange mechanism between the zeolite powder and the soluble species in the second-step treatment. As discussed in section 3.1.1, when calcium concentration in the feed is very high, as in the case of the sulphuric acid leachate feed, the removal efficiency for strontium is expected to be very low as evidenced by the results in Table B.9. In the case of the $10^{-2} \mathrm{M}$ cupferron leachate feed to the process, the complexed state of strontium together with a relatively high concentration of calcium, seem to be responsible for lowering the strontium removal efficiency.

Other than the ion-exchange action of zeolite in the second-step of the process, the presence of large amounts of iron in the leachate feed appears to have a significant beneficial effect for strontium-90 removal. With $0.1 \mathrm{M} \mathrm{FeCl}_{3}$ leachate, 
the treatment process gives the maximum efficiency for strontium removal (99.9\%) and also provides the best filtrate quality of about twenty times the US drinking water limit (see Table B.10 in Appendix B). The results thus reveal that strontium adsorption to ferric hydroxide flocs in the first-step of the treatment scheme may also be a significant factor in the overall process performance. It is interesting to note that the federal discharge limit for strontium-90 in groundwater according to the Code of Federal Regulations (10 CFR 20) is $11 \mathrm{~Bq} / \mathrm{L}$ [Campbell and Collins, 1988]; It seems that the best filtrate water quality of $7 \mathrm{~Bq} \mathrm{Sr}-90 / \mathrm{L}$ obtained in the tests is below the federal discharge limit for groundwater.

For all the leachate feeds tested, the final filtrate quality for iron was consistently well below the drinking water limit, irrespective of its concentration in the feed solution. For the leachate solutions produced by leachants that are strong electrolytes, the ion exchange behaviour correlated very well with calcium concentration in the feed solution: a) as calcium concentration in feed increases, exchange capacity of zeolite for calcium increases and b) ion exchange capacity of zeolite for $\mathrm{Sr}-90$ decreases as calcium concentration increases in the feed. Since cupferron chemistry is quite different from electrolyte behaviour [Muthuswami et al., 1985], the ion exchange capacity data was found to be outside the correlation envelope.

Based on the above results for strontium-90, it appears that the treatment process may have to be designed considering the following factors: a) adequate concentration of precipitating metals in the first process step to promote strontium removal by adsorption/ion exchange, and 2 ) sufficient zeolite concentration in the second process step, or 3) deployment of multiple zeolite additions followed by microfiltration in the second process step.

\subsection{Pilot-Scale Test Results}

\subsubsection{Simulated Solutions}

On the basis of the bench-scale results, pilot-scale optimization tests were performed using simulated waste solutions containing the three groups of contaminants, heavy metals, radionuclides and volatile organics. A three-step process configuration was considered. The lime-soda precipitation was employed to precipitate the heavy metals and a major fraction of calcium and strontium-85. As the uranyl carbonate is not a stable precipitate, additions of lime and soda were implemented as two successive process steps. This sequence permits removal of most of the heavy metals as metal hydroxide precipitates in the first process step. only calcium and some strontium- 85 need be removed by carbonate precipitation in the second process step.

It was observed that the addition of zeolite powder to a solution containing the precipitates behaved similar to ion exchange in solution without the precipitate being present. This lead to sequential additions of zeolite powder within a waste conditioning step involving precipitation or adsorption by powdered activated carbon. The distribution of solids addition on the different process steps not only reduced the suspension loading on microfiltration, but also provided effective removal of contaminants throughout the process steps. This flexibility of superimposing multiple removal steps in a single waste conditioning step was a favourable and essential condition to provide good quality effluents. 
Representative performance data obtained from sequential chemical conditioning of the waste combined with microfiltration are presented in Tables C.1 to C. 3 (Appendix $C$ ). The data demonstrate that cationic forms of the inorganic contaminants can be removed effectively to produce a filtrate effluent that is at or below the drinking water limit (DWL). This also applies to non-contaminant metal impurities such as calcium and iron used in the experiments.

Volatile organic removal was achieved in the third and final process step. The results show excellent removal efficiencies, but the filtrate quality was an order of magnitude greater than the DWL of $0.005 \mathrm{mg} / \mathrm{L}$ for benzene and trichloroethylene. The data given in Table C. 2 involving a waste solution containing relatively high concentrations of the contaminants demonstrate that the proposed process is suitable for a wide range of influent contaminant levels.

\subsubsection{Groundwater}

The daia obtained for the removal of strontium-90 from groundwater at the CRL site is given in Table C.4 (Appendix C). As discussed in section 3.1.2, the groundwater contains about $120 \mathrm{mg} / \mathrm{L}$ of carbonate 1ons. As a result, no further addition of carbonate as soda was made. A two-step process using caustic precipitation in the first step and zeolite addition in the second-step produced a final filtrate quality for strontium-90 of $8 \mathrm{~Bq} / \mathrm{L}$.

\subsubsection{Groundwater Spiked with Contaminants}

In an effort to determine the filtrate quality of a groundwater spiked with other contaminants, a three-step process was tested. The results are given in Table C.5. The data demonstrate the complete removal of all the contaminants in the waste solution except strontium-90 and cesium-137 to levels less than the drinking water limit. The concentration of cesium-137 was an order of magnitude greater than the DWL, whereas strontium-90 was almost two orders of magnitude greater than the DWL. The data suggest that a distributed addition of zeolite between the first and the second step of the process, similar to the bench-scale tests (section 3.1.2), would have produced better quality effluent.

\subsubsection{Soil Leaching Results and Leachate Treatment}

\subsubsection{Contaminated Soil Leaching}

The Sr-90 contaminated soll from the CRL site aquifer plume occupied a bed depth of $70 \mathrm{~cm}$ and a total volume of $4.59 \mathrm{~m}^{3}$ in the soll-leach apparatus. Measured porosities averaged $44.8 \%$ and the bulk density was estimated to be $1.46 \mathrm{~g} / \mathrm{cm}^{3}$. The total mass of contaminated soil amounted to 6.69 metric tonnes. Using the 0.45 porosity obtained from the pre-leachant soil cores, the total pore volume in the contaminated soil was $2,065 \mathrm{~L}$. The mean grain size was $0.1 \mathrm{~mm}$ and hydraulic conductivities, estimated by Hazen's procedure, varied from $1.7 \times 10^{-3}$ to $9 \times 10^{-3}$ $\mathrm{cm} / \mathrm{s}$. The results showed that mixing during filling of the bin was not complete. Samples from the $40-50 \mathrm{~cm}$ depth interval at locations $M-1$ and $M-2$ (see Figure A.7, Appendix A) were significantly higher in silt content than the remaining samples resulting in variations in the hydraulic conductivities as much as a factor of 5 . Despite the heterogeneities of the soil mass in the apparatus, it was ascertained that it should not be great enough to seriously affect the leaching test. 
Strontium-90 soil concentrations ranged from 28.2 to $53.4 \mathrm{~Bq} / \mathrm{g}$, with a mean of 41.8 and a standard deviation of $5.04 \mathrm{~Bq} / \mathrm{g}$ ( $12 \%$ of the mean). Summing the quantities calculated for each section of the bin, the total. infilal Sr-90 content was 280 $\mathrm{MBq}$.

Following completion of the leaching experiment, the solls were re-sampled for Sr-90 content. Concentrations of residual $\mathrm{Sr}-90$ were substantially more variable than those observed inftially, ranging from 2.8 to $14.7 \mathrm{~Bq} / \mathrm{g}$ with a mean of 5.33 and a standard deviations of $3.62 \mathrm{~Bq} / \mathrm{g}$ ( $68 \%$ of the mean). High residual $\mathrm{Sr}-90$ concentrations at the base of locations $M-4$ and $M-6$ are interpreted as evidence of a slightly premature termination of the addition of leachant. The total residual inventory of $\mathrm{Sr}-90$ was calculated to be $35.8 \mathrm{MBq}, 13 \%$ of the initial content. This residual percentage indicated that the soll-washing experiment did succeed in stripping most of the sorbed $\mathrm{Sr}-90$ that can be leached without undertaking essentially complete destruction of the soils. Total Sr-90 removed from the soll determined by the difference between the pre- and post-leach analyses was $245 \mathrm{MBq}$ (6.62 mC1).

Under the experimental conditions, we would expect that essentially all iron in solution would be present as $\mathrm{Fe}^{3+}$, but we analyzed for total iron, $\mathrm{Fe}^{\mathrm{t} o t}$. Figure C.l (Appendix C) displays the $\mathrm{Sr}-90$ concentrations, $\mathrm{pH}$, and relative concentrations of $\mathrm{Cl}^{-}$and $\mathrm{Fe}^{\mathrm{t}} \mathrm{Ot}$. From the start to the end of the leachant addition $(\sim 60 \mathrm{~h})$, the surface of the contaminated soils in the bin were kept flooded with the $0.015 \mathrm{M}$ $\mathrm{PeCl}_{3}$ (to a depth that fluctuated between 3 and $10 \mathrm{~cm}$ ) continuously. At that point, the leachant solution amounting to $11,160 \mathrm{~L}$ ( 5.45 pore volumes) containing a total of $29.3 \mathrm{~kg}$ of $\mathrm{FeCl}_{3}$ had been added. The free solution on top of the sediments was less than $3 \mathrm{~cm}$ deep. Feed to the apparatus was then switched to clean water, and water addition was continued for about 36 hours.

Flow rate through the contaminated soil in the apparatus varied between 2.65 and $3.10 \mathrm{~L} / \mathrm{min}$ during the test and the average rate was $2.89 \mathrm{~L} / \mathrm{min}$, under essentlally unit hydraulic gradient. Using a horizontal cross-sectional area of the bin of $65,570 \mathrm{~cm}^{2}$, the calculated bulk hydraulic conductivity of the contaminated sediments was $7.3 \times 10^{-4} \mathrm{~cm} / \mathrm{s}$. This lower value for hydraulic conductivity than provided by the Hazen estimates described earlier might suggest that slightly lower-permeability zones in the apparatus were frequent enough to control overall flow through the system.

The chloride data (Figure C.1) indicate that heterogeneities in the apparatus were small enough that the breakthrough curve was not substantlally skewed. Relative chloride concentrations at the end of the addition of $\mathrm{PeCl}_{3}$ to the soll-leach apparatus were slightly above 1.0 as a result of variations in the feed solution concentration. Other than this effect, the concentration decrease was essentially symmetrical with the rising limb.

The leachate solution $\mathrm{pH}$ shows a dramatically different time profile. After passage of 0.5 pore volumes, the $\mathrm{pH}$ dropped rapidly from 1 ts initial value of 6.0 to 2.8. There were subsequent declines to 2.4 and, following the switch of feed solution from $\mathrm{FeCl}_{3}$ to water, a slow rise to 3.5 at the termination of the experiment. The sharp inttial decrease is approximately coincident with the initia. increase in $\mathrm{Cl}^{-}$concentrations, and reflects the arrival of leachant through the most permeable pathways avallable. Subsequent additions of $\mathrm{H}^{+}$appear to have led to the establishment of a temporary equilibilum where ion exchange and hydrolysis buffered the leachate $\mathrm{pH}$ value above the input solution $\mathrm{pH}$ value of 1.6. The slow rise in $\mathrm{pH}$ following the switch to clean water feed reflects the gradual replacement of exchangeable $\mathrm{H}^{+}$by other cations present in the water. 
The increase in total iron concentrations follow a profile similar to that of the chloride, but delayed by approximately a quarter of a pore volume. This is attributed to the temporary precipitation of iron engendered by the buffering of $\mathrm{pH}$ in the sediments. With further additions of $\mathrm{H}^{+}$, that iron is re-dissolved, leading to peak concentrations in the leachate that exceed those in the input solution. After termination of the $\mathrm{FeCl}_{3}$ input, $\mathrm{Fe}^{\mathrm{t} o t}$ concentrations decline in concert with those of the chloride. Total recoveries of both $\mathrm{Cl}^{-}$and $\mathrm{Fe}^{\text {tot }}$ were found to be within $5 \%$ of the inputs, indicating no net stripping of iron from the contaminated sediments.

The concentration profile for Sr-90 features a rising limb that tracks the increase in $\mathrm{Cl}^{-}$closely. The initial pore water in the soil averaged $2.8 \mathrm{~Bq} / \mathrm{mL}$, and $\mathrm{Sr}-90$ concentrations in the leachate began to rise in concert with the decrease in $\mathrm{pH}$ and increase in leachate $\mathrm{Cl}^{-}$, peaking at $38.0 \mathrm{~Bq} / \mathrm{mL}$ after passage of 2.3 pore volumes of leachant. This rapid rise is attributed to the near-instantaneous release of Sr-90 retained on the contaminated soils by fon exchange. The long trailing tail on the Sr-90 elution profile is a reflection of kinetic controls on radiostrontium release.

In the course of this experiment, the total removal of $\mathrm{Sr}-90$ was $235 \mathrm{MBq}$. This is within 5\% of the $244 \mathrm{MBq}$ removal figure provided by the pre- and post-leach soll analyses. Given the heterogeneity in the soils in the leaching apparatus, this is satisfactory agreement. Using the pre-leach soll $\mathrm{Sr}-90$ inventory of $280 \mathrm{MBq}$, the leachate and post-leach soll data provide total radiostrontium removal percentages of $84 \%$ and $87 \%$, respectively. Thus, the pilot-scale test was able to release almost all of the $\mathrm{Sr}-90$ that can be readily stripped. These results are in excellent agreement with the bench-scale leaching results discussed in section 3.1.3.

In summary, the pilot-scale soll leaching test performed using sediments contaminated with Sr-90 from the CRL Waste Management Area "B" aquifer plume has confirmed that dilute $\mathrm{FeCl}_{3}$ can remove the leachable fraction of the radiostrontium. Passage of 5.5 pore volumes of $0.015 \mathrm{M} \mathrm{FeCl}_{3}$ through 6.7 metric tonnes of contaminated sands and silts released between 84 and $87 \%$ of the sorbed Sr-90. On the basis of the bench-scale leaching results, there exists a potential to reduce the concentration of ferric chloride to $0.01 \mathrm{M}$ or lower in future large scale soll-leach experiments.

\subsubsection{Contaminated Soil Leachate Solutions}

A limited number of experiments were carried out using the contaminated soil leachate solutions produced from pilot-scale soll leaching tests (section 3.2.4.1). Table C. 6 in Appendix C presents the data obtained from a five-step process. The results suggest that although strontium-90 removal is very high in the first two stages, the filtrate produced contains a high concentration of strontium-90 $(2700$ $\mathrm{Bq} / \mathrm{L})$. The removal efficiency declines drastically in the last three stages, giving a final filtrate quality that is 143 times the drinking water quality. The overall poor quality of the filtrate even after five-steps of processing suggest that the presence of high concentrations of chloride anions (about 0.045 mol/L) may have hindered the Ion exchange of strontium-90 with the zeolite. The chloride anion has a strong binding energy for the strontium-90 cation. A lime-soda treatment with zeolite additions distributed over four process steps also give relatively poor overall strontium-90 removals (Table C.7). 
The leachate treatment results show that the proposed process using natural zeolite powders may not be suitable for applications involving high ionic strength acidic $(\mathrm{pH} \sim 2$ to 3 ) waste solutions. It is suspected that the use of a fixed-bed zeolite ion-exchange column, after a iron removal step, is not expected to perform any better. Breakthroughs corresponding to bed volumes of 50 to 100 may not be ruled out. One alternative would be be to use a different ion-exchange material, or to search for a suitable alternative leachant for soll washing that is capable of removing strontium-90 from contaminated solls at low ionic strengths.

\subsubsection{Dewatering of Dilute Suspensions}

\subsubsection{Low-Temperature Evaporation}

In the evaporation tests, only the operating time was varied, keeping other variables such as evaporation temperature and external feed temperature essentially constant. The feed suspensions contained total suspended solids of 1 to 6 weight percent. The concentration range represents typical values for suspended solids in the concentrate stream generated in the previous microfiltration step. The results obtained with different feed solutions and suspensions are summarized in Table C.8 (Appendix $C$ ). Since the evaporation temperature was self-regulated by the unit depending on the vacuum set-point, the overall evaporation temperatures for the different feeds were similar (about 2 to $10^{\circ} \mathrm{C}$ ). Depending on the duration of operation, the average evaporation rate varied from about $0.1 \mathrm{~L} / \mathrm{min}$ to about $0.17 \mathrm{~L} / \mathrm{min}$. The overall volume and mass balances showed a loss (typically about 0.2 to $1 \mathrm{~L}$ ). The loss is attributed to the liquid holdup in the pipe lines and in the condenser. At steady-state operations involving large volume feeds, the loss due to holdup is expected to be insignificant, as compared with the total feed volume processed.

The water quality index values for the overhead condensate with respect to lead, cadmium, uranium, iron, cesium-137 and strontium-85 are far less than one, suggesting that the overhead water produced by the low-temperature evaporation unit is of a superior quality to the maximum permissible concentrations for contaminants in drinking water. The radioactivity of the feed solution refers only to the activity of the isotopes in the supernatant solution. The bulk of the activity is contained by the zeolite in the suspension and was not released in the vapour phase during dewatering. For strontium-90 in the feed, the quality of the overhead condensate stream was 'less than' twice the US drinking water limit of $0.35 \mathrm{~Bq}$ $\mathrm{Sr}-90 / \mathrm{L}$. The precision in the chemical analysis for Sr-90 was the limiting factor resulting in the slightly lower quality of the overhead stream.

When evaporating feed suspensions containing powdered carbon loaded with benzene and trichloroethylene, the overhead water quality deteriorated significantly depending on the duration of the operation. As expected, the combined actions of vacuum stripping and steam stripping prevalent in the evaporator caused a continuous removal of the volatile organics. The results suggests that the lowtemperature evaporation may have the potential to remove volatiles completely from the powdered carbon suspension. The residue, after desired dewatering, may be reused as an adsorbent charge to the conditioning tank for organic removal. The overhead condensate could be subjected to a downstream organic destruction step. An alternative route to avold release of organics from the carbon would be to carry out dewatering in a filter press at room temperature. 
In summary, dewatering of suspensions can be achieved by the use of low-temperature evaporation. The suspensions (containing 1 to 6 weight percent of suspended solids, constituting inorganic precipitates and ion exchanged zeolite) can be volume reduced by a factor of 10 to 20 . For these concentration factors, the overhead water quality for cadmium, calclum, lead, uranium, iron, strontium-85 and cesium-137 was less than the maximum allowable concentrations listed in the U.S. Drinking Water Limits. Within the analysis precision for $\mathrm{Sr}-90$, the overhead effluent is acceptable for discharge.

\subsubsection{Pilter Pressing of Suspension Produced by Microfiltration}

A limited number of filter pressing experiments were performed to assess its effectiveness to concentrate dilute suspensions generated by the microfiltration process. Results obtained from filtering simulated suspension feeds are given in Table C.9. In general, suspensions which contained metal precipitates (e.g. iron) produced filtrates with lower solid content than suspensions which contained only zeolite. This effect may be attributed to the gelatinous nature of ferric hydroxide. The hydroxide adheres to the filter cloth and captures small particles of zeolite preventing them from passing through the filter. The average amount of solids found in the filtrates was about $9 \mathrm{ppm}$. For the cadmium-lead-1ron system, the concentration of iron in the filtrate was about $0.6 \mathrm{mg} / \mathrm{L}$, whereas cadmium and lead had levels of about $0.15 \mathrm{mg} / \mathrm{L}$. There was some indication that cadmium and lead levels in the filtrate were lower when lime was used to precipitate the metals instead of sodium hydroxide. The majority of the filter cake produced had a solid content of 40 weight percent (dry weight).

Microfiltration of the filtrate from filter pressing reduced the metal concentration to about $0.02 \mathrm{mg} / \mathrm{L}$, suggesting that the relatively low quality filtrate from the filter press is predominantly the result of particulates leaking through the filter.

In summary, the preliminary test results suggest that filter pressing can be incorporated as the dewatering step to produce concentrated secondary waste acceptable for further treatment before disposal. A concentration factor for 20 appears to be viable. The off-spec filtrate generated during the dewatering step can be recycled to the microfiltration step.

\subsection{Process Design}

A process involving sequential steps of chemical treatment and cross-flow microfiltration, together with a dewatering step (either evaporation and/or filter pressing) is, on the basis of the test results performed at the pilot-scale, sufficient to remove mixed waste contaminants from contaminated waters. A schematic of the overall process is shown in Figure D.l (Appendix D). For practical and economic considerations, it appears that dewatering by filterpressing is the preferred route for applications involving large throughputs. However, for site demonstrations involving 1 to $2 \mathrm{gpm}$ waste throughputs, lowtemperature evaporation equipment is suitable to minimize the secondary waste volume.

The key chemical treatment steps are: 1) pH adjustment by lime addition combined with zeolite powder addition to precipitate, ion exchange, adsorb and scavenge most of the heavy metals along with iron, and some radionuclides and organics; 2) a sequential addition of a natural zeolite ion exchange/adsorbent powder to remove radionuclides, residual heavy metals and some organic contaminants; and 3 ) a sequential addition of powdered activated carbon with or without zeolite powder as a polishing step to remove organics and residual radionuclides. 


\subsection{CRL Site Demonstration}

\subsubsection{Single-Stage Chemical Treatment-Hicrofiltration Process}

A simplified field-scale process flowsheet, consisting of one-stage chemical treatment combined with microfiltration and a dewatering step, was constructed on the basis of the pilot-scale results. The equipment was configured to remove strontium-90 in the presence of iron, calcium and other alkaline earth metals from ground and surface waters contaminated from the leaching waste at the Area "B" site on the CRL property. The treatment facility, with a throughput capacity of $2 \mathrm{gpm}$, was housed in winterized "temporary" buildings located close to the groundwater collection well (see Figure A.3, Appendix A).

The results of the demonstration tests showed that contaminated groundwater containing strontium-90 at levels of 1500 to $5000 \mathrm{~Bq} / \mathrm{L}$ was treated effectively, to produce a filtrate quality of less than $10 \mathrm{~Bq} \mathrm{Sr}-90 / \mathrm{L}$, which met the current Canadian drinking water limit for strontium-90 (10 Bq/L) but not the U.S. drinking water limit $(0.35 \mathrm{~Bq} / \mathrm{L})$. The $\mathrm{Sr}-90$ concentration in soll leachates produced from contaminated soil leaching tests with ferric chloride solution were reduced from 15 000 to $28000 \mathrm{~Bq} / \mathrm{L}$ to 100 to $900 \mathrm{~Bq} / \mathrm{L}$ using a single-stage treatment. The soil leachate results suggest that a two-stage chemical treatment combined with microfiltration will be necessary to provide a filtrate water quality of 1 to $10 \mathrm{~Bq}$ $\mathrm{Sr}-90 / \mathrm{L}$, whereas a single-stage treatment was adequate for the treatment of contaminated groundwater.

\subsubsection{Fixed-Bed Ion Exchange Column Tests}

Several fixed-bed column tests were performed using contaminated groundwater from the CRL site. Two columns of internal diameters of $10 \mathrm{~cm}$ and $3 \mathrm{~cm}$ were employed. The columns were packed with the zeolite TSM-140D (particle size: $0.425 \mathrm{~mm}$ to 0.85 $\mathrm{mm}$ ) in the amount of $3.05 \mathrm{~kg}$ and $0.34 \mathrm{~kg}$, respectively. The feed flow rate to the columns were kept between nine and ten column volumes per hour. The waste feed was preflltered using a set of $5 \mu \mathrm{m}$ pore-size cartridge filters.

The influent feed consisted of iron, calcium, carbonate and strontium-90. The composition of the feed was: [iron] $=6.4$ to $20.7 \mathrm{mg} / \mathrm{L}$; [calcium] $=65.2$ to 70.1 $\mathrm{mg} / \mathrm{L} ;$ [carbonate] $=119$ to $122 \mathrm{mg} / \mathrm{L}$; and [strontium-90] $=3616$ to $3644 \mathrm{~Bq} / \mathrm{L}$.

The iron and carbonate concentrations in the effluent leaving the column were steady at $0.2 \mathrm{mg} / \mathrm{L}$ for iron (detection $1 \mathrm{lmit}$ ) and at about $120 \mathrm{mg} / \mathrm{L}$ for the carbonate species. The concentration profiles for calcium and strontium-90 as a function of column bed-volume are shown in Figure C.2. In these experiments, the target $\mathrm{Sr}-90$ concentration for column breakthrough was set at $10 \mathrm{~Bq} / \mathrm{L}$, corresponding to the current Canadian Drinking Water Limit for Sr-90. The Sr-90 analysis detection limit was $1 \mathrm{~Bq} / \mathrm{L}$. Data given in Figure C.2 show that both columns exhibit breakthrough around 150 bed volumes for $\mathrm{Sr}-90$ and 100 bed volumes for calcium. The results corresponded to an average zeolite concentration of about $6400 \mathrm{mg}$ per litre of waste influent treated. The average amount of $\mathrm{Sr}-90$ retained by the zeolite bed up to 150 bed volumes corresponded to $554 \mathrm{~Bq}$ per gram of zeolite. A preliminary analysis of the microfiltration process' ability to provide the same effluent quality suggests (see Table C.4, Appendix C) that zeolite requirements will be half that needed for the fixed-bed column. Further tests are in progress to validate this analysis. 
Preliminary bench-scale solidification tests were conducted with samples of the secondary waste slurry consisting of iron precipitate and zeolite powder. A waste form prepared with Portland cement ( 80 to $90 \%$ on dry weight basis) is a promising product for storage/disposal. Leachate tests with the solidified product gave a leachate quality that was within an order of magnitude of the drinking water limit for the various immobilized contaminants.

Routine treatment of contaminated ground and surface waters at the CRL site is in progress. A schematic flowsheet is shown in Figure C.3. 


\subsection{TECHNOLOGY STATUS}

\subsection{Technology Development Evaluation}

\section{1,1 Technology Capability}

The approach to the development of the waste treatment technology, has been to consider a process configuration that is simple to operate and control, modular to facilitate easy scale-up, and portable for use in site remediations. Furthermore, the process must be sufficiently generic so that it can be used for a variety of applications involving a wide spectrum of waste contaminants and compositions. The process should use common, low-cost chemical agents and waste by-products. small- to adium-scale vaste processing requirements involving waste feed flow rates in the range of 1 to $300 \mathrm{gpm}$ are the most suitable rarget applications for the technology.

The direct contacting of the waste solution with low-rost powdered adsorbent/ion exchange materials in concert with low pressure cross-flow microfiltration offers an efficient way to remove multicomponent contaminant species from complex waste solutions. In this mrde of operation, there exists suficient flexibility to use mixtures of powders, finis produced as waste or by-products from other industrial cectors such as mining, etc. Since the cost of the chosen adsorbent is generally low, the material would not require additional unit operations for regeneration of the exhausted material. In a sense, this mode of mass transport represents a "discrete stage" or "differer:e" type contacting. Of course, when a large number of equilibrium stages are needed the powder addition-microfiltration separation method will not be practical.

Traditionally, a fixed-bed column configuration is appropriate when multiple equilibrium stages are required within an adsorption/ion exchange unit to achieve a specific removal rarget. Invariably, a larger particle size of adsorbent is used and the bed is regenerated after a predetermined loading of contaminants, and the regenerated solution is subjected to further treatment before disposal of the contaminants. The same goes with the bed material, which must be disposed after a specific life cycle (varies from a few months to a few years depending on the type of application and material used). In this way, the adsorbent material is reused for several cycles until it loses its ability to perform. Neverthless, the material has to be eventually disposed of. In chemical engineering such an operation is reierred co as "differential" processing.

A conventional process (see Figure D.2, Appendix D) for metal removal involyes precipitation, flocculant addition, suspension separation by gravity settling, thickening and clarification, and finally sludge dewatering. Tyrolcally, the overall processing time would be of the order of several hours. The same treatment can be accomplished using a sinple configuration using a single-step precipitition combined with microfiltration and a final dewatering step with a filter press. By comparison, the overall processing time for the microfiltration process would be many times lowr:r than the conventional process. It is important to note that microfiltration using a $0.2 \mu \mathrm{m}$ cut-off pore-size membrane does not require large particle size solids for solid-liquid separation. Thus, the lengthy times needed to produce flocs can be substantially reduced. The only growth required is that the fi:ial precipitate particle size must be slightly greater than the membrane cut-off pore size. Consequently, through a proper adjustment of the solution $\mathrm{pH}$, the required particle size cor microfiltration can be achieved within one hour. 
The focus in this development project was not in the selection of the best precipitation agents, or adsorption/ion-exchange materials. The main goal was to devise a scheme based on membrane separation processes that separates sizeenlarged contaminant ions in waste solutions. The goal was to keep the process sufficiently generic so that it can be applied to a variety of appilcations involving mixed wastes containing heavy metals, radionuclides, volatile and nonvolatile organics. Basically, the three types of chemical treatment employed are well known: 1) precipitation, 2) ion exchange and 3) adsorption. But the way they are used in conjunction with microfiltration membrane separation for a complex waste feed is the novelty of the process. Aiso, the process was not developed to handle a simple-to-treat, large volume waste stream. The emphas is was on simplicity, controlability, portability and adaptability.

The proposed process also includes the means to deal with impurities such as calcium and iron in the feed because they are common in groundwaters and leachates produced as result of chemical washing of contaminated soils. The process goal was not to remove iron and calcium. Since iron hydroxide/iron oxide system is well known for its scavenging and co-precipitation actions on metal cations, it may be considered advantageous to add small amounts of iron (e.g. 20 to $50 \mathrm{mg} / \mathrm{L}$ ) to the waste if needed. For the type of microfiltration system employed in the pilot-scale study, iron precipitates are readily and efficiently removed.

The presence of calcium interferes with the removal of certain cations by ion exchange, especially the removal of radiostrontium. Calcium and strontium (85 or 90) behave almost identically in precipitation, adsorption and ion exchange. The concentration of calcium is typically tens and hundreds of ppm while radioactive strontium occurs in concentration levels of $\mathrm{ppm}$ to fractions of $\mathrm{ppm}$. With this incompatability and stringent standards for radioactive strontium discharge levels (whether it be drinking water limit, or any other limits corresponding to discharge to waterways), it is a difficult removal problem to consider all by itself. The use of lime-soda precipitation solves the calcium issue by efficiently removing it from solution. Hence, subsequent to the addition of inorganic exchange iledia allows excellent radiostrontium removal efficiencies to be realized.

The use of certain precipitation agents depends on specific applications. In our process development, the choice of lime and soda were preferred because: a) they are relatively inexpensive, b) they are compatible with cementious materials in producing a suitable waste form for the disposal of the secondary wastes produced by the process, c) they remove calcium and magnesium resulting in the enhanced removal of radiostrontium, and d) they are compatible with the natural zeolite material. If a specific application demands the use of sulfide precipitation, this makes the case for microfiltration process even more attractive. It should be also noted that even relatively difficult to dewater hydroxide metal precipitates can be handled using cross-flow microfiltration combined with air backwashing. It is believed that the proposed process can use other precipitation agents effectively including sulfide ( $\mathrm{FeS}, \mathrm{Na}_{2} \mathrm{~S}$ ), starch xanthates and potassium ferrates.

In summary, the separation process is perceived to have a number of advantages:

1) the process allows direct contact of contaminants to metal precipitates such as iron, to powdered adsorbent and to ion exchange materials; the process uses effectively natural impurities such as iron, calcium etc. present in the groundwater/soil leachates; iron removal is excellent. 
2) the combined action of precipitation, coprecipitation, adsorption and ion exchange, and cross-flow microfiltration is used effectively to remove contaminants into a concentrated suspension while generating a dischargeable quality water effluent as described previously;

3) the use of powdered ion exchange/adsorbent materials provides high contaminant removal efficiencies and fast kinetics;

4) low-cost waste by-products of ion exchange/adsorbent materials can be utilized;

5) a cross-flow microfiltration with an air backwash system is used which makes the process suitable for continuous operation and demands less space than conventional systems, and the process provides a filtrate that is low in suspended solids;

6) the process system can be readily turned on and off without a long transient time, and modular construction ylelds a large range of flow rate options and is portable;

7) the process is sufficiently generic and can be adapted easily to treat waste solutions containing a variety of radioactive and hazardous species;

8) difficult to dewater suspensions can be handled with relative ease; lengthy time requirements for particle growth in conventional water treatment will not be necessary.

These attributes all add up to a significant degree in improvement over existing technologies.

\subsubsection{Cost Analysis}

In this section, preliminary cost estimates for the chemical treatmentmicrofiltration process (Figure D.1, Appendix D) to treat waste throughputs of 2 $\mathrm{gpm}$ and $300 \mathrm{gpm}$ are summarized. The cost estimates have been grouped under five main categories: 1) total equipment cost, 2) total installed cost, 3) basic operating cost, 4) total disposal costs and 5) total site related costs. A summary of mass balance calculations for the $2 \mathrm{gpm}$ plant and the assumptions used are given in Table D.1 (Appendix D). The same assumptions are applicable to the $300 \mathrm{gpm}$ plant and the mass flow rates of process streams will be increased by a factor of 150 . The cost estimates are presented in Table D.2 (Appendix D) for a 2 gpm plant and in Table D.3 for the scaled-up $300 \mathrm{gpm}$ plant.

Capital recovery is not included in the estimation of costs. The approach developed by US EPA, that is applicable to typical cleanup activities at Superfund and Resource Conservation and Recovery Act (RCRA) corrective action sites [Evans, 1990], has been followed. The cost factors for the different cost categories reported in a recent study [EPA, 1991] for a treatment process have been used. Costs for individual equipment and equipment systems have been extracted from the data compilation by Gumerman et al. [1986]. Cost data for large tanks and pumps have been extracted from the report by Hall et al. [1982]. The cost calculations have been translated to 1991 (4th quarter) value using appropriate values of the Marshell and Swift Indices. In addition, key equipment and reagent costs have been obtained directly from the suppliers of the items. The costs presented in this analysis are expected to be only order-of-magnitude ( -30 to 50 percent) estimates, as defined by the American Association of Cost Engineers [Humphreys, 1984]. 
For the purpose of this cost analysis, it is assumed that the proposed process will treat contaminated groundwater containing heavy metals, radionuclides and small amounts of organics on a continuous cycle, 24 hours per day, 260 days for 1 year. During a 1-year period, the $2 \mathrm{gpm}$ plant will treat approximately 0.75 million gallons and the $300 \mathrm{gpm}$ plant will treat approximately 112 million gallons. The annual operating costs have been estimated as one-time costs. It should be noted, however, that most groundwater remediation projects may cover a significantly longer period of time.

The following assumptions were made regarding the contaminated ground water influent, effluent and operating conditions. The waste influent has a $\mathrm{pH}$ of about 6. It contains about $90 \mathrm{mg} / \mathrm{L}$ of heavy metals (e.g. cadmium, uranium, lead, etc.), $170 \mathrm{mg} / \mathrm{L}$ of non-contaminant metal impurities (such as calcium, iron and sodium), $2 \times 10^{-5} \mathrm{mg} / \mathrm{L}$ of radionuclides, and about $30 \mathrm{mg} / \mathrm{L}$ of organics. Chemical additions (in $\mathrm{mg} / \mathrm{L}$ ) involve: lime $=180$ and zeolite powder $=1000$ (process step $\$ 1$ ); soda $=390$ and zeolite powder $=3000$ (process step $\$ 2$ ); powder carbon $=2000$ and zeolite $=500$ (process step $\# 3$ ). Each process step involves chemical addition and conditioning of the solution, followed by cross-flow microfiltration. The concentrated suspensions ( 2 to $6 \mathrm{wt} . \%$ solids) produced by the microfilters are dewatered by filter pressing to produce a cake of about $40 \%$ solids (dry weight), while the filtrate from filter pressing is recycled to the first process step. The final filtrate from microfiltration step $\$ 3$ is $\mathrm{pH}$ adjusted to about 8.5 and discharged to the waterways, or into the groundwater system. The treated water is targeted to have a quality lower than, or within one order of magnitude of the drinking water limit for contaminants permissible under U.S. regulations. The majority of the secondary waste produced is cemented and disposed as a solid radioactive waste. The small volume secondary waste containing the organics is subjected to thermal treatment and the ash immobilized into a waste form, and disposed. Details of removal efficiencies at each process step are given in Table D. 1 (Appendix D).

The results of the cost analysis show that the annual operating costs, excluding secondary waste disposal and site preparation costs, amount to $\$ 367770$ for the 2 gpm plant and $\$ 4.1$ million for the $300 \mathrm{gpm}$ plant. The annual operating costs associated with the secondary waste disposal by the $2 \mathrm{gpm}$ plant is $\$ 50487$ and that of the $300 \mathrm{gpm}$ plant is $\$ 8.2$ million. Depending on the nature of the site, the total site related costs may amount to approximately $\$ 1$ million for the small plant and \& 14.7 million for the large treatment plant. One-time capital (installed) costs have been estimated to be about $\$ 275000$ for the $2 \mathrm{gpm}$ plant and about $\$ 4$ million for the $300 \mathrm{gpm}$ plant.

A summary of the cost data, expressed in dollars per gallon of waste water treated, is given in Table 4.1. Excluding the secondary waste disposal costs and site related costs, the basic operating cost to treat one gallon of waste is $\$ 0.49$ for the $2 \mathrm{gpm}$ plant and $\$ 0.037$ for the $300 \mathrm{gpm}$ plant.

A conventional process was configured (Figure D.2, Appendix D) with standard unit operations including precipitation, clarffication, flocculation, thickening, fixed-bed ion exchange/adsorption with regeneration, and filter pressing. Because of the lack of reliable performance data for the integrated system, cost estimates were not made for the reference plant. Consequently, a cost-benefit analysis for the proposed process (Figure D.1) with the reference process was not performed. 


\subsubsection{Reliability}

Our experience in testing multi-component synthetic waste solutions, relatively simple groundwaters and groundwaters spiker with multiple contaminants have shown contaminant removal efficiencies to typically exceed $99.9 \%$. For the range of feed concentrations tested, the average removal efficiency translates to contaminant concentrations in the treated waste water to be within one order of magnitude of the maximum allowable concentration in the drinking water as governed by U.S. regulations. These results are supported fully by the quality controlled tests and analysis performed by different technicians at different times.

Table 4.1: Cost Summary expressed as Dollar per Gallon of Waste Treated

Basis: 3 shifts/d; $260 \mathrm{~d} / \mathrm{y}(6420 \mathrm{~h} / \mathrm{y})$ Operation

Total Amount of Waste Treated in 1 year

Costs per gallon of waste treated:

Basic operating cost:

that includes:

Labour

Material, supplies \& chemicals Analytical

Equipment replacement \& repair

Energy consumption
2 gpm Plant 300 gpm Plant

$748700 \mathrm{gal} \quad 112320000 \mathrm{gal}$

S. per gallon of waste treated

0.49

0.037

0.361

0.094

0.056

0.009

0.010

0.006

0.024

0.005

0.001

0.001

Annual disposal costs associated with secondary waste generated by the process
0.07
0.073

Basic operating + Disposal Costs

0.56

0.110

Total operating cost for site remediation

1.96

0.241

The process is easy to implement and is fully controllable. It is a closed process in the sense that fugitive emissions and other uncontrolled losses are expected to be minimal.

A capacity of $2 \mathrm{gpm}$ for the final treated effluent appears to be suitable scale for site demonstration purposes. Being principally a membrane-based process, scale-up to larger capacities can be accomplished readily. Process optimization for specific application can be performed with ease on-site.

Similar to most other standard processes, about 75 pounds of secondary solid waste (dry weight)/1000 gallon of waste treated, must be dealt with. 


\subsubsection{Regulatory Requirements}

The regulatory requirements depend on specificity of site characteristics, effluent discharge points, permitting stipulations (National Pollutant Discharge Blimination System, NPDES, requirements), etc. In the development of the proposed process, we arbitrarily set a goal of producing treated water effluent having a water quality that is similar to drinking water. This limit was intentionally chosen to allow the process to be sufficiently generic for easy adaptability to various applications involving contaminated groundwater and soll leachate solutions. Although the proposed process has the adaptability and the flexibility to meet the U.S. Drinking Water Limit, in reality, this imposed stringent limit may not be necessary. Waste solutions containing a total of 7 contaminants and two key inorganic metals, calcium and iron were used to demonstrate process flexibility. The seven contaminant species represent the three generic classes of contaminants (heavy metals, volatile organics and radionuclides). By adequately choosing the conditions for chemical treatment, all the above contaminants can be removed from the waste solutions to concentrations similar to the drinking water. The heavy metals and inorganic metal impurities can be confidently reduced to levels lower than that for the drinking water. The radionuclides and organics can be reduced to levels meeting the drinking water standard, although levels within an order of magnitude of the drinking water limit are easily achieved.

While applications may not require such stringent effluent discharge targets to be met, the expectations of performance of the process have been achieved in these series of trials conducted on behalf of the Department of Energy. Lesser expectations can be accommodated by choosing fewer number of stages, by less alteration of process chemistry or by the addition of lower concentration of sorbents.

\subsection{Technology Integration Evaluation}

\subsubsection{Need for Ancillary Technologies}

Depending on the nature of site application, the proposed technology can be used either as a stand-alone process, or in conjunction with other technologies. For example, the proposed technology is not suitable on a stand-alone basis for applications involving soll decontamination. A soll washing technology would be necessary in the front-end to provide an adequate soil leachate feed to our process. Simllarly, if the waste solution to be treated contains high concentrations (several hundred parts-per-million) of volatile organics, then a pretreatment of the waste influent that uses established technologies such as airstripping [e.g., La Mori and Gunther, 1989], or in-situ decontamination of organics from soils using a horizontal-well technology [Kaback et al., 1989] prior to soil washing, would be needed. Although the bulk of the organics would be removed by these technologies, the presence of residual organics, say in the range tens of parts-per-million or lower, would be unavoidable. The residual organics would be carried through the soil washing process and would enter our process for further treatment, where the organics would be removed along with radionuclides and other heavy metals.

As our treatment method is not a disposal technology, ancillary technologies, including solidification of secondary wastes by a cementation matrix, and suitable on-site or off-site thermal treatment technologies would be needed to handle activated carbon loaded with organics. 
Some eight process steps, representing a number of integrated unit operations, would be needed to complete the overall treatment train. The integrated process would provide the desired contaminant removal, waste-volume reduction, and waste disposal. Among the eight process steps, our process accounts for the four process steps $(3,4,5,6)$. It is expected that the other process steps $(1,2,7$, 8) can be implemented by adopting established technologies. The eig,ht principal process steps are:

Process Step 1: Air Stripping for the removal of volatile organics from contaminated soil/solution.

Process Step 2: Contaminated soil washing system.

Process Step 3: Chemical treatment-microfiltration (MF-1) for the removal of heavy metals.

Process Step 4: Chemical treatment-microfiltration (MF-2) for the removal of radionuclides, residual metals and some organics.

Process Step 5: Chemical treatment-microfiltration (MF-3) for the removal of organics, and remaining radionuclides.

Process Step 6: Dewatering suspensions generated by process steps 3, 4 and 5.

Process Step 7: $\quad$ Solidification \& disposal for concentrated suspensions produced from process step 6 .

Process Step 8: Treatment \& Disposal of organic containing streams.

\subsubsection{Future Development}

The innovative technology that has been developed from the cost shared program appears to be positioned for additional trials to permit more detailed and thorough analysis of its capabilities to remediate radioactive and chemically hazardous waste solutions and groundwaters. The successful application at CRL where modular equipment was installed clearly demonstrated its capability to purify both groundwater and soil washing solutions in a cost effective and efficient manner.

The experience gained from performing bench-scale experiments to establish the chemistry control will minimize trial and error attempts in future field test programs. The results from dynamic bench-scale tests are directly translatable to successful operations in a field environment. Risks associated with new applications will be minimized by first conducting small volume bench-scale experiments to establish acceptable effluent discharge criteria and expectations of secondary waste volumes. The additional experience also provides some assurance of operating within a budgetary envelope once the bench-scale tests have been fully evaluated to determine the required stages and chemical dosages.

The process which has been developed has the potential to use a variety of powdered admixtures and can accommodate wide fluctuations in process chemistry to achieve desired reductions in contaminants. Since the equipment can be skid mounted and thus modular, it can be integrated with other processes to achieve the desired remediation goal. Technology risk can be reduced by examining its 
performance simultaneously with other alternative technologies simply by operating the process in a parallel configuration. The technology can be quickly assembled and placed in a field environment once the outcome of bench-scale trials are known. The process can be assembled and moved to a field location giving it significant scheduling advantages over other technologies which must be assembled in the fleld.

The technology meets most of the expectations of Innovative processes. It can be used alone or with other technologies to produce dischargeable effluent. It creates a small volume of waste solids which can be easily immobilized or left in a dewatered state. The outcome is dependent on criteria required for disposal. The technology addresses two fundamental concerns of hazardous waste sites; their dissimilarity and the physical and chemical complexities. The technology has been demonstrated in a "stand-alone" field test, and has been successful in the treatment of simulated waste solutions containing radionuclides, toxic metals and organics. The process appears to be an appropriate addition to supplement existing remediation technology. The process technology as developed from extensive laboratory and field tests has a high probability of meeting with success if applied with some prior knowledge of the chemistry of the remediation site. The probability of success is rated highly and there is a high degree of confidence in the process succeeding in new applications where such success can be determined solely on the basis of the outcomes from inexpensive bench-scale tests. The success of the technology at one site at CRL has prompted additional CRL sites to be investigated for similar applications. This endorsement of the technology will permit further field experience to be gained and will result in fewer commissioning bottlenecks in future demonstrations. 


\subsection{REFERENCES}

\subsection{Literature Cited}

BETZ [1980], "Handbook of Industrial Water Conditioning", BETZ Laboratorles Inc., Trevose, PA, 8 th edition.

Campbell, D.0. and Collins, E.D. [1988], "Use of Inorganic Sorbents for Vaste Treatment at Oak Ridge National Laboratory", paper presented at IABA Research Coordination Meeting on "Use of Inorganic Sorbents for Liquid Waste Treatment and Backfill for Underground Repositories", Mol, Belgium, September 5-9.

DOE [1991], "Quality Assurance Project Plan", Document submitted by AECL Research to Argonne National Laboratory, Argonne, Revision No. 2.0, 24 April.

DuPont, A. [1988], "Treatment of heavy metal liquid sludge waste with lime", Proc. The 9 th National Conf. Superfund '88, November 28-30, Washington, D.C., pp. 398-402.

BPA [1980], "Control and treatment and technology for the metal finishing industry - sulfide precipitation", EPA Summary Report, EPA-625/8-80-003, Environmental Protection Agency, April.

EPA [1990], Drinking Water Limit (U.S.) from 40 CFR 141, Rev. July 1, 1990 and NBS Handbook 69 for Radionuclides.

EPA [1991], "E.I. DuPont De Nemours \& Company/Oberlin Filter Company Microfiltration Technology-Applications Analysis Report", Research and Development RD 681, United States Environmental Protection Agency, Report BPA/540/A5-90/007, October.

Evans, G. [1990], "Estimating Innovative Technology Costs for the SITE Program", Journal of Air and Waste Management Association, 40(7), pp.10471051 .

Gumerman, R.C., Burris, B.E. and Hansen, S.P. [1986], "Small Water System Treatment Costs", Pollution Technology Review No. 136, Noyes Data Corp., New Jersey.

Hall, R.S., Matley, J. and McHaughton, K.J. [1982], "Current Costs of Process Equipment", Chemical Engineering, April 5, pp. 81-116.

Humphreys, K.K. [1984], "Project and Cost Engineers' Handbook", 2nd Edition, Maracel Dekker, New York, NY.

Kaback, D.S., Looney, B.B., Corey, J.C., Wright, L.M. and Steele, J.L. [1989], "Horizontal Wells for In-Situ Remediation for Groundwater and Soils", Proc. 3rd National Outdoor Action Conf., Orlando, Florida, pp. 121-135 (Published by National Water Well Association, Dublin, Ohio).

La Mori, P. and Guenther, J., [1989], "In Situ Steam/Air Stripping", Forum on Innovative Hazardous Waste Treatment Technologies: Domestic and International, Atlanta, Georgia, June 19-21, 1989, pp. 112-115. 
Marcant, B. and David, R. [1991], "Experimental Evidence for and Prediction of Micromixing Effects in Precipitation", AIChE Journal, vol. $37(11)$, pp. $1689-1710$.

HcGregor, W. [1990], Steelhead Speciality Minerals, Spokane, Washington (509-328-5685), private communication.

Muthuswami, S.V., Vijayan, S. and Woods, D.R. [1985], "Flotation of Uranium Ores in Canada: Part II - Cupferron Adsorption on Uranium Oxide, Quartz, Illite, and a Uranium Ore from Elliot Lake", Canadian J. Chem. Eng., vol. 63, pp. 650-661.

Peters, R.W., Ku. Y. and Bhattacharyya, D. [1985], "Evaluation of recent treatment techniques for removal of heavy metals from industrial wastewaters", AIChE Symp. Series, No. 243, vol. 81, pp. 165-203.

\subsection{Publications}

Buckley, L.P., Vijayan, S., Wong, C.F., Maves, S.R. and Erickson, M.D. [1991], "Laboratory-Scale Study of a Process for Contaminant Removal and Waste Volume Reduction to Remedlate Groundwater Containing Mixed Waste", Proc. Pirst International Mixed Waste Symposium, Baltimore, Maryland, August 26-29.

Buckley, L.P., Killey, R.W.D., Vijayan, S. and Vong, C.P. [1992], "Treatment of Groundwater and Soll-Wash Leachate Solutions Containing Mixed Waste Contaminants", paper in press, Proc. Hazardous Waste Management Intl. Meeting- SPECTRUM'92, Boise, Idaho, August 23-27. 


\subsection{ACKNOWLEDGEMENTS}

This work was partially sponsored and funded by the Office of Technology Development, office of Environmental Restoration and Waste Management, U.S. Department of Energy, managed by Argonne National Laboratory (Contract No. 021124415). The authors thank B. Ellarma, J. Young, P. Mattie, S. Bokwa and G.J. McConeghy (Chalk River Laboratories, ABCL Research) for their assistance with the experiments, and Drs. B.M. Attas, D. Chan, R. Hamon, S. Leblanc, Mr. R. Taylor and the Analytical Services Group, and Dr. C.N. Murphy and the Quality Assurance Group (Whiteshell Laboratories, AECL Research, Manitoba) for providing chemical analysis of numerous vater samples. Thanks are also due to Drs. E.L. Cooper and J. Torok (Chalk River Laboratories) for stimulating discussions on the subject of low-level strontium-90 analysis and sorption behaviour of cesium and strontium. The authors are grateful to Drs. N.J. Baskid and M.D. Erickson (Argonne National Laboratory) for providing advice throughout the project period. The authors also wish to acknowledge colleagues at Argonne National Laboratory for providing a stimulating critique of our Phase 1 Interim report. The authors also wish to thank Drs. D.J. Cameron and D.R. Champ, and Mr. L.A. Moschuk (Chalk River Laboratories) for their constant encouragement and advice throughout the project. 
APPENDIX $\triangle$ - FACILITIES AND EQUIPKERT
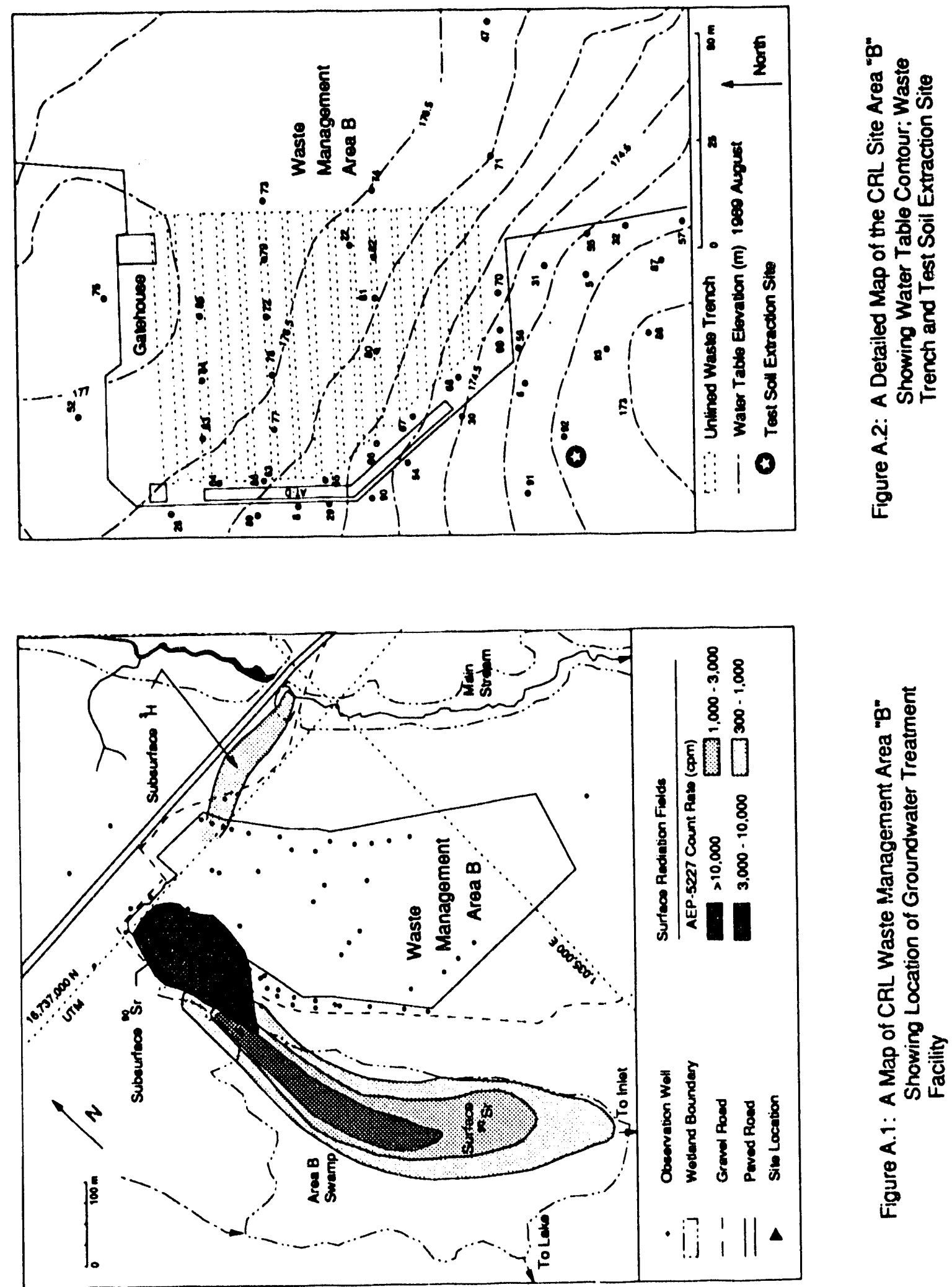


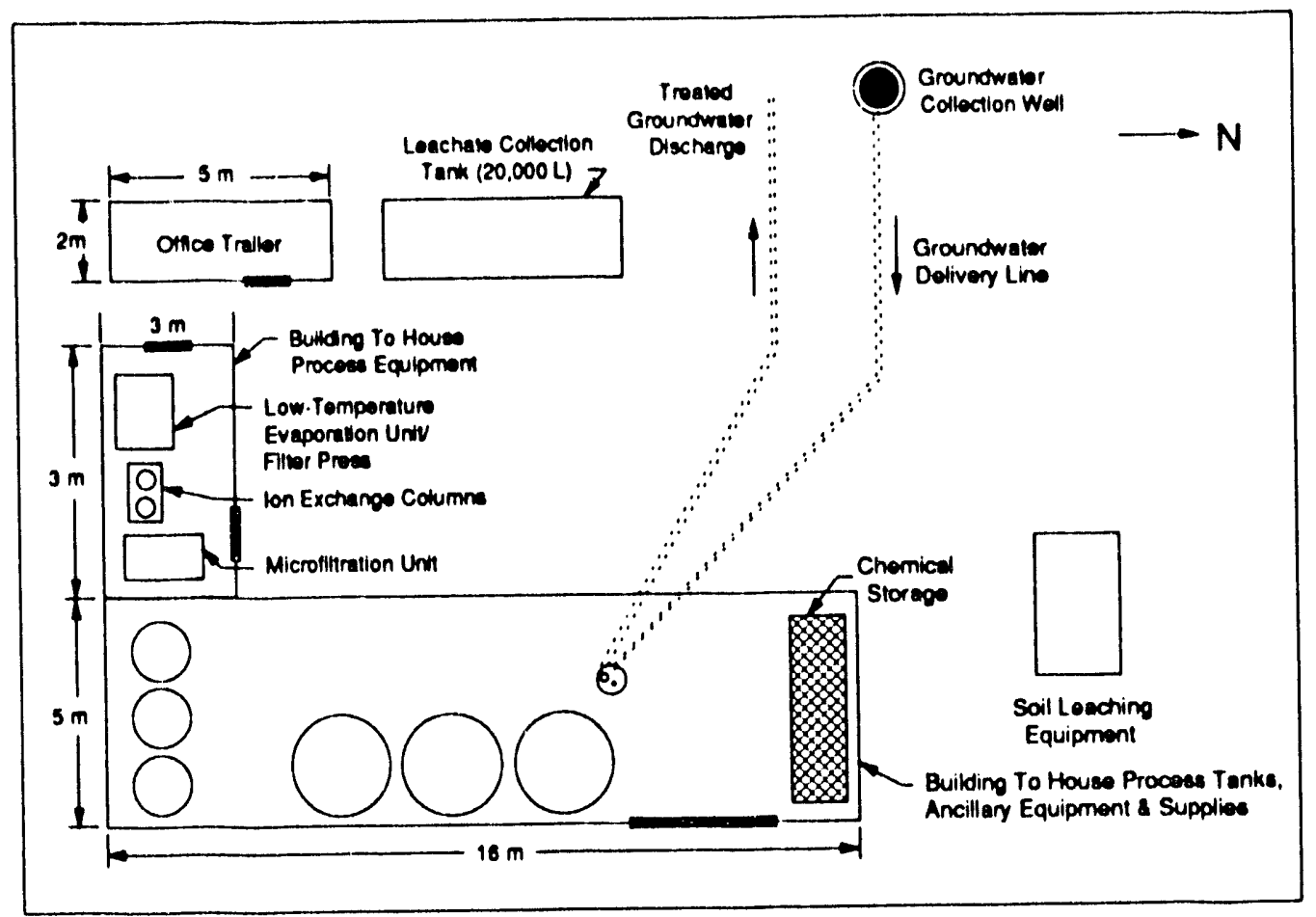

Figure A.3: CRL Site, Area "B" Remediation Facility Layout

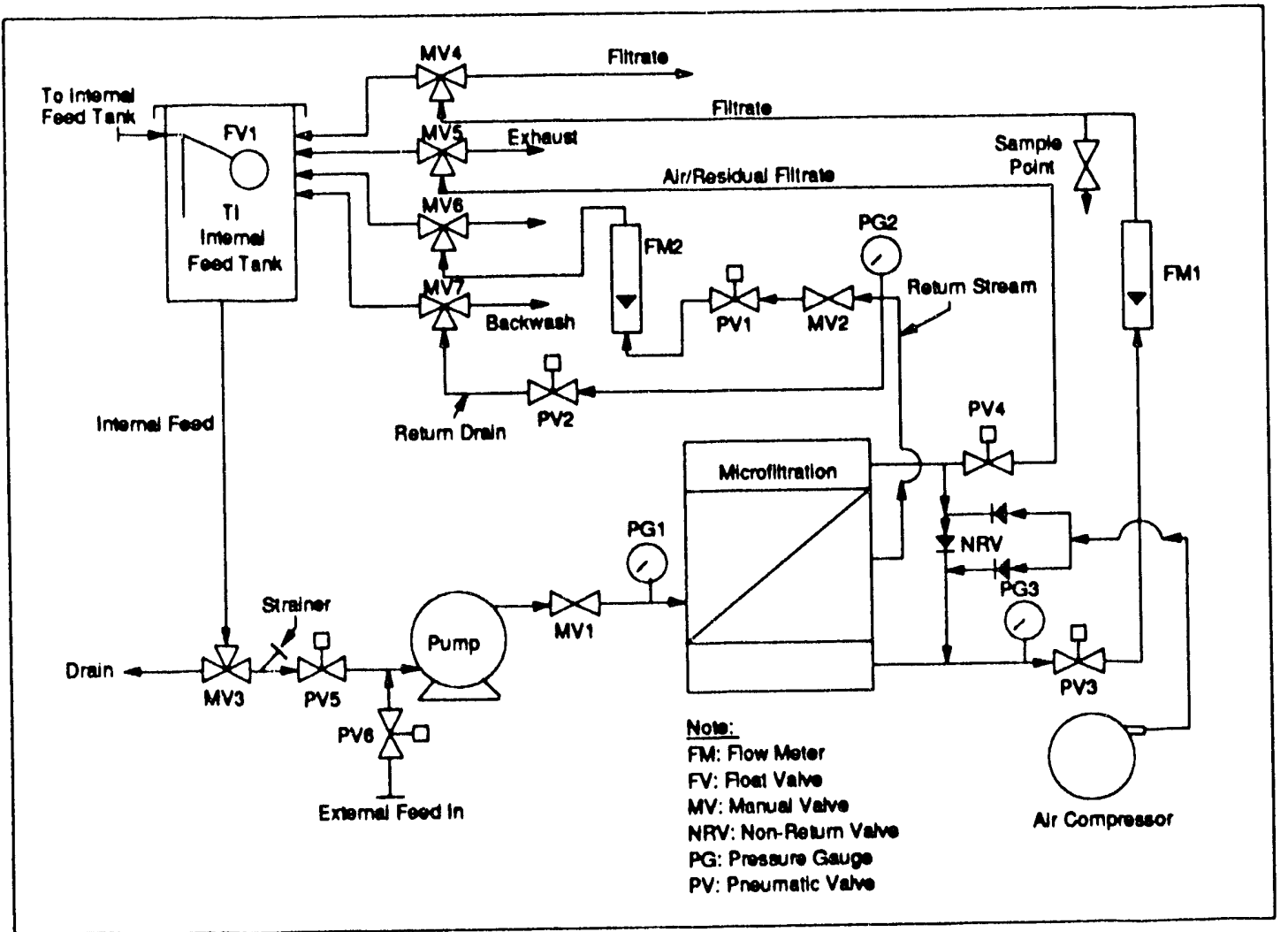

Figure A.4: Schematic of the Pilot-Scale Microfiltration Unit 


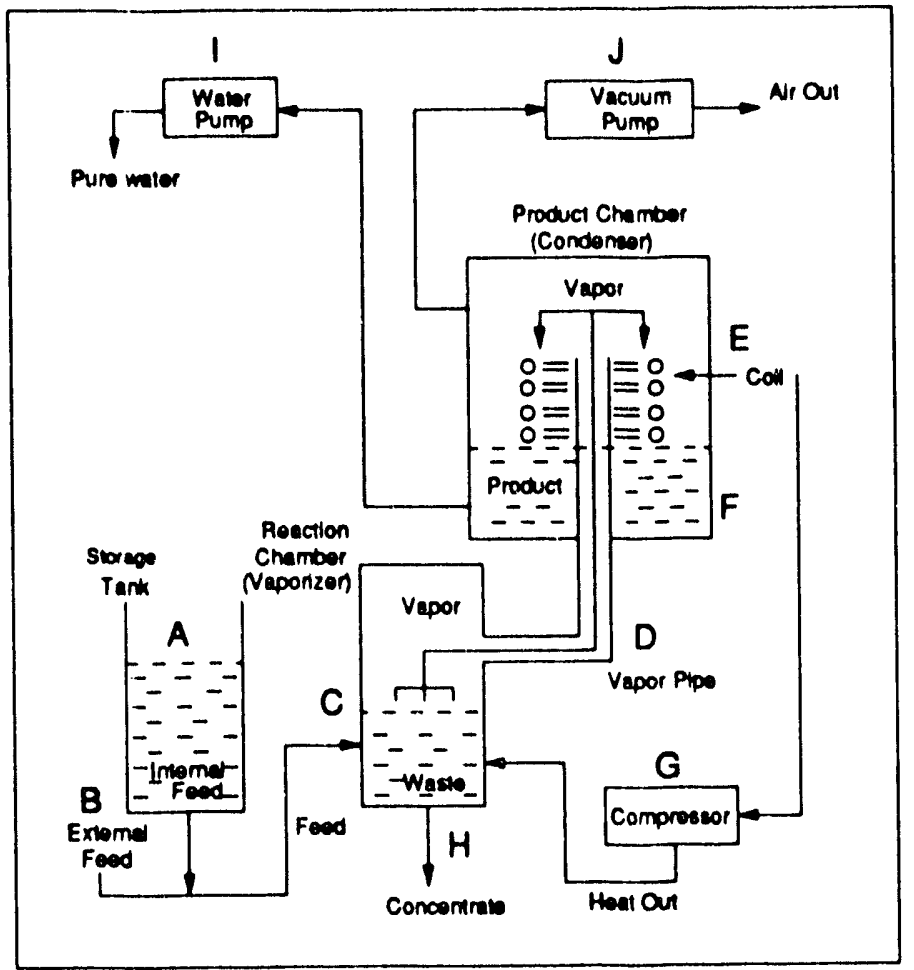

Figure A.5: Schematic of the low-temperature vaporization unit

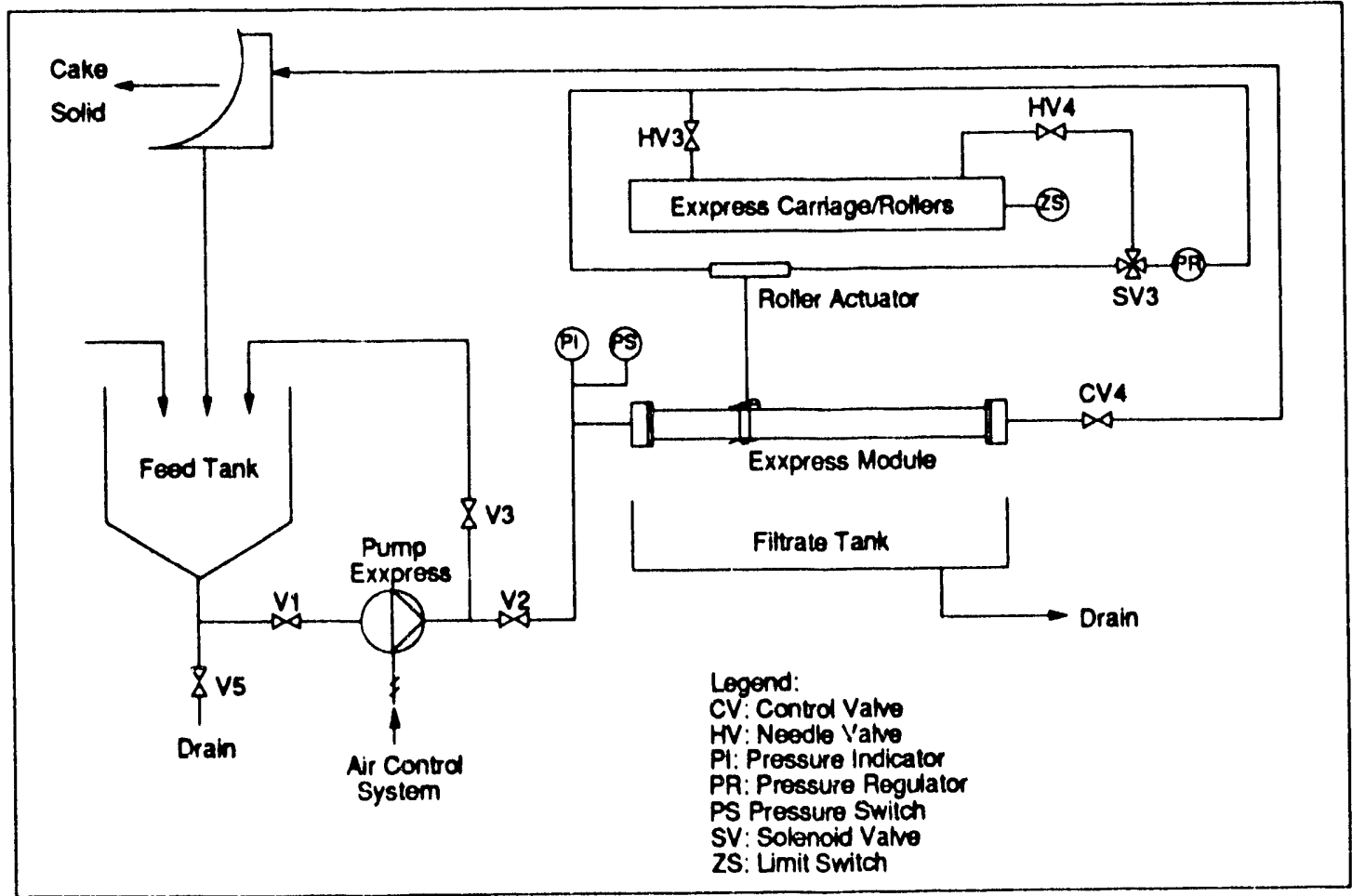

Figure A.6: Schematic of the Filter Press 


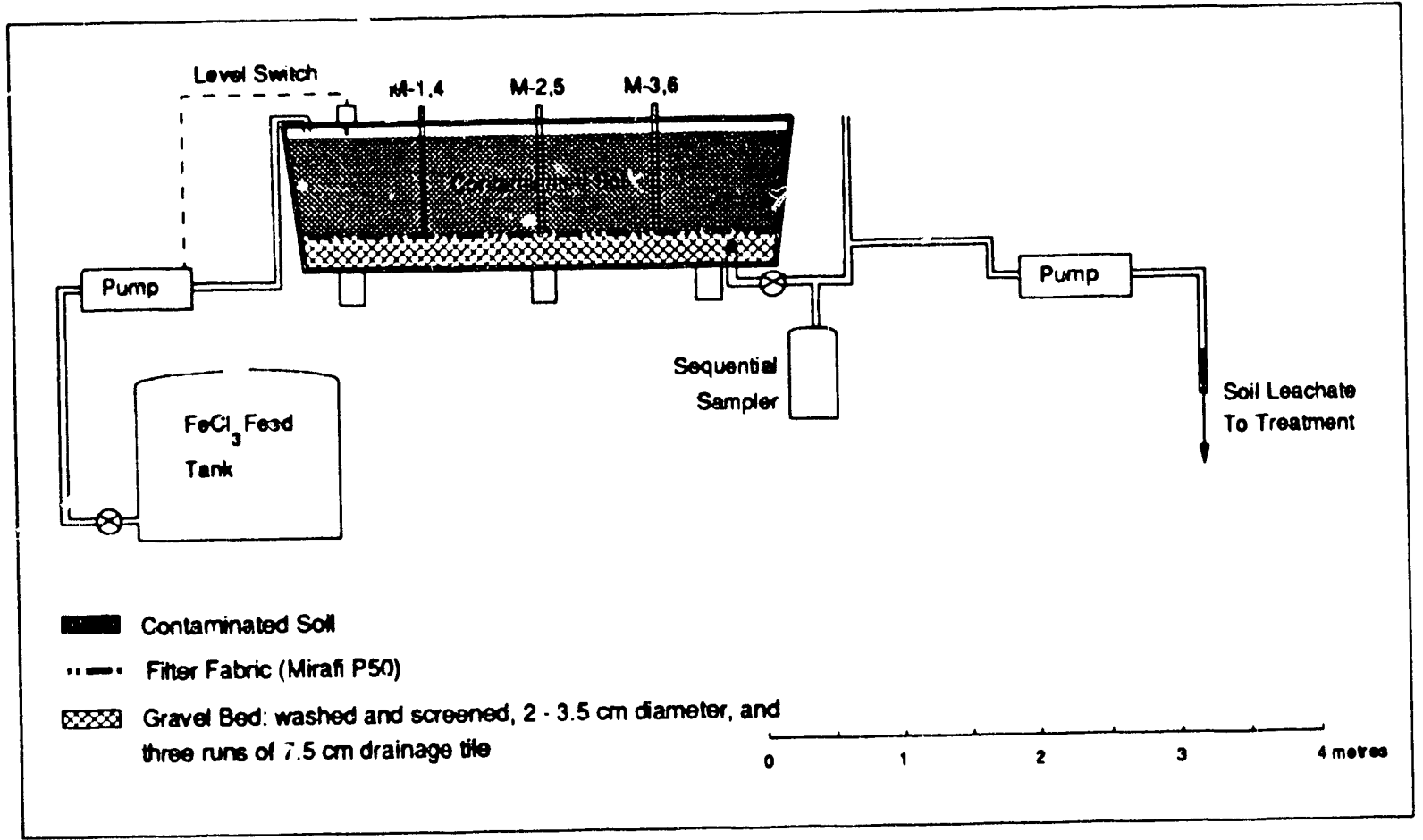

Figure A.7: Schematic of the soil leaching equipment 


\section{APPENDIX B - PERFORHANCR DATA PROH BENCH-SCALE TESTS}

Table B.1: Removal of Heavy Metals and Radionuclides by a Two-Stage Chemical Treatment-Microfiltration Process (Teat No. 3E)

\begin{tabular}{|c|c|c|c|c|c|c|}
\hline $\begin{array}{l}\text { Stream/ } \\
\text { Parameler }\end{array}$ & $\begin{array}{l}{[\mathrm{Cd}]} \\
(\mathrm{mg} / \mathrm{L})\end{array}$ & $\begin{array}{c}{[\mathrm{PO}]} \\
(\mathrm{mg} / \mathrm{L})\end{array}$ & $\begin{array}{l}{[\mathrm{U}]} \\
(\mathrm{mg} / \mathrm{L})\end{array}$ & $\begin{array}{l}{[\mathrm{Fe}]} \\
(\mathrm{mg} / \mathrm{L})\end{array}$ & $\begin{array}{r}\mathrm{Sr}-85] \\
(\mathrm{Bq} / \mathrm{L})\end{array}$ & $\begin{array}{l}{[\mathrm{Cr}-137]} \\
(\mathrm{Bg} / \mathrm{L})\end{array}$ \\
\hline Feed & 2.89 & 10.2 & 0.461 & 52.6 & 5750 & 85000 \\
\hline FWQI & 289 & 204 & 7.683 & 175.3 & 38.33 & 22973 \\
\hline Filtrute (MF2) & 0.0074 & $<0.02$ & $<0.038$ & 0.074 & 56.5 & 484 \\
\hline \% Removal & 99.74 & $>99.80$ & $>91.76$ & 99.86 & 99.02 & 99.43 \\
\hline (28) & 2.57 & 3.97 & 8.03 & 2.96 & 8.28 & 6.80 \\
\hline PWQI & 0.74 & $<0.4$ & $<0.63$ & 0.25 & 0.37 & 130.81 \\
\hline (2s) & 0.04 & 0.014 & 0.071 & 0.018 & 0.22 & 18.54 \\
\hline
\end{tabular}

Note: The water quality indices FWQI and PWQI are defined as a ratio of conuminant concentration in waste feed $(F)$ or in treated filtrate $(P)$ to the maximum allowable concentration of the contaminans under U.S. EPA regulations; 2s: 2 sigma statistics.

1. $\mathrm{NaOH} \mathrm{GH}=9.5 ; t=4 \mathrm{hI}$
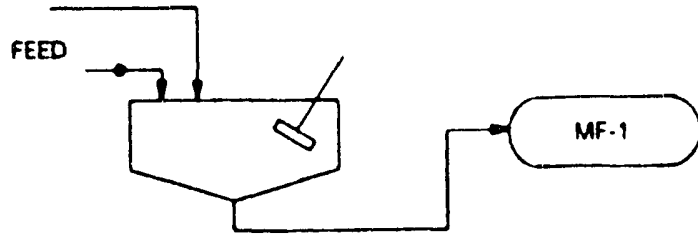

Notes: $t=$ conditioning time; $\bullet$ sampling point:

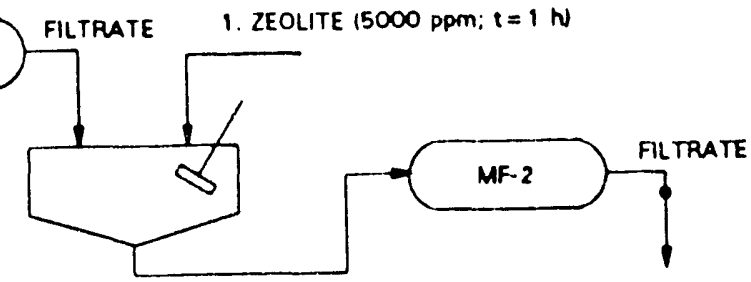

MF = microfiltration

Table B.2: Cesium-137 Removai Dala from a Pure Solution Using - Two-Stage Zeolite Conditioning-Microfiltreation Process. No pH adjuatment, no other metals in feed (Tea No. 7000B)

\begin{tabular}{|c|c|c|}
\hline \multirow[t]{2}{*}{ Parameter/Stream Deacription } & \multicolumn{2}{|l|}{ Suge No. } \\
\hline & MF-1 & MF-2 \\
\hline $\begin{array}{l}\text { Feed concentration (Cs-137 Bq/L) } \\
\text { (2s) } \\
\text { Feed water quality Index (FWQD) } \\
\text { Filtrate concentration (Cs-137 Bq/L) } \\
(2 s) \\
\text { Percent Cs-137 removal } \\
(2 s) \\
\text { Filtrate water quality index (PWQD) } \\
(28)\end{array}$ & $\begin{array}{l}25600 \\
(1332) \\
6918.9 \\
185 \\
(38.2) \\
99.28 \\
(7.34) \\
50.0 \\
(10.3)\end{array}$ & $\begin{array}{l}185 \\
(38.2) \\
50 \\
3.7 \\
(3.55) \\
98.0 \\
(29) \\
1.0 \\
(0.96)\end{array}$ \\
\hline
\end{tabular}

1. ZEOUTE $6 \mathrm{PH}=5$ B: $250 \mathrm{ppm:} t=15 \mathrm{minl}$
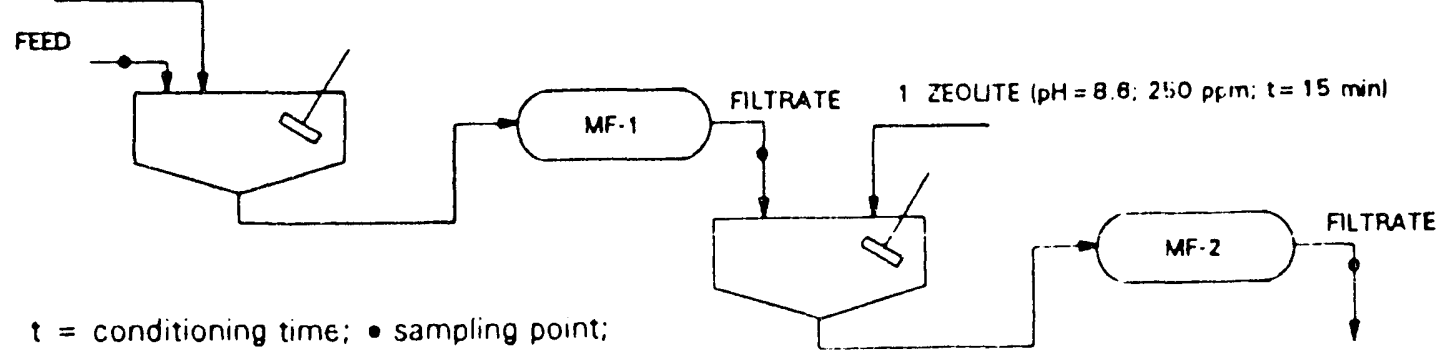

Notes: $t=$ conditioning time; $\bullet$ sampling point: $M F=$ microfiltration 
Table B.3 : Removal of Srontium 85 in the Atrence of all other cations by a SincleStage Zoolite Trealmeat Followed by Microfiltration (Teat No. SRKD.1)

\begin{tabular}{|l|c|}
\hline Stream/Parameter & $\begin{array}{c}\text { [St 85] } \\
(\mathrm{Bq} / \mathrm{L})\end{array}$ \\
\hline $\begin{array}{l}\text { Feod } \\
\text { FWOI }\end{array}$ & 52281 \\
Filtrate (MF1) & 348.5 \\
Percent Removal & 96.2 \\
(28) & 99.82 \\
PWOI & 0.965 \\
(20) & 0.641 \\
\hline
\end{tabular}

1. ZEOUTE $(\mathrm{PH}=6.9 ; t=24 \mathrm{~h})$

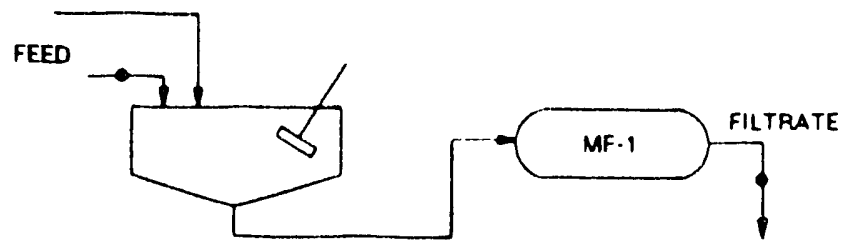

Notes: $t=$ conditioning time; $\bullet$ sampling point; MF = microfiltration

Table B.4: Removal of Srontium BS in the presence of Calcium but free of all otber Cations by a Single Stage Zoolite Treatment Followed by Microfiltration (Teat No. XAK.1)

\begin{tabular}{|l|c|c|}
\hline $\begin{array}{l}\text { Streary/ } \\
\text { Parameter }\end{array}$ & $\begin{array}{c}{[\mathrm{Ca}]} \\
(\mathrm{mg} / \mathrm{L})\end{array}$ & $\begin{array}{c}{[\mathrm{Sr} 8 \mathrm{8}]} \\
(\mathrm{Bq} / \mathrm{L})\end{array}$ \\
\hline Feed & 44.9 & 28749 \\
FWOI & 0.225 & 191.7 \\
Filtate & 23.8 & 2919 \\
\% Removal & 46.99 & 89.85 \\
(2s) & 2.25 & 6.75 \\
PWOI & 0.119 & 19.46 \\
(2s) & 0.002 & 0.99 \\
\hline
\end{tabular}

1. ZEOUTE $(P H=9.5 ; t=22 \mathrm{~h})$
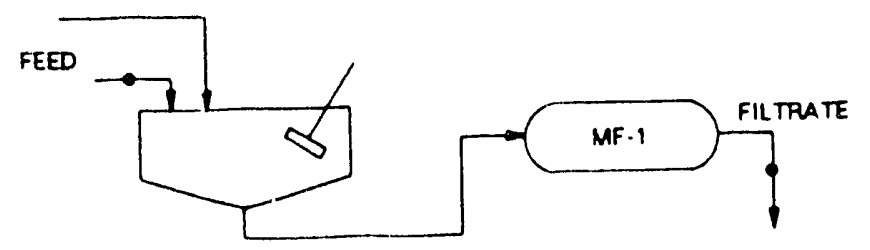

Notes: $\quad t=$ conditioning time: - sampling point; $\mathrm{MF}=$ microfiltration

Note: The water quality indices FWQI and PWOI are defined as a natio of contaminant concentration in waste feed (F) or in treated filtrate (P) to the maximum allowable concentration of the contaminant under U.S. EPA regulations; 2 s: 2 sigma statistica. 
Table B.5: Removal of Heavy Metals and Radionuclides by a Two-Suge Chemical Treatment-Microfiltration Process (Ten No. 1009B)

\begin{tabular}{|c|c|c|c|c|c|c|c|}
\hline $\begin{array}{l}\text { Stream/ } \\
\text { Parnmeter }\end{array}$ & $\begin{array}{l}{[\mathrm{Cd}]} \\
(\mathrm{mg} / \mathrm{L})\end{array}$ & $\begin{array}{l}{[\mathrm{Pb}]} \\
(\mathrm{mg} / \mathrm{L})\end{array}$ & $\begin{array}{l}\mathrm{U}] \\
(\mathrm{mg} / \mathrm{L})\end{array}$ & $\begin{array}{l}{[\mathrm{Fe}]} \\
(\mathrm{Ing} / \mathrm{L})\end{array}$ & $\begin{array}{l}\mathrm{Ca}] \\
(\mathrm{mg} / \mathrm{L})\end{array}$ & $\begin{array}{r}{[\mathrm{Sr}-8 \mathrm{8S}]} \\
(\mathrm{Bq} / \mathrm{L})\end{array}$ & $\begin{array}{c}{[\mathrm{Cr}-137]} \\
(\mathrm{Bg} / \mathrm{L})\end{array}$ \\
\hline $\begin{array}{l}\text { Feed } \\
\text { FWQI } \\
\text { Filtrate(MF1) } \\
\text { \% Removal } \\
\text { (2ø) } \\
\text { PWQI } \\
(2 s)\end{array}$ & $\begin{array}{c}1.78 \\
178 \\
0.0045 \\
99.75 \\
2.83 \\
0.45 \\
0.03\end{array}$ & $\begin{array}{c}9.44 \\
188.8 \\
<0.02 \\
>99.79 \\
3.97 \\
<0.4 \\
0.01\end{array}$ & $\begin{array}{l}1.83 \\
30.5 \\
<0.038 \\
>97.92 \\
5.79 \\
<0.63 \\
0.071\end{array}$ & $\begin{array}{c}46.4 \\
154.6 \\
0.002 \\
99.99 \\
3.03 \\
0.007 \\
0.001\end{array}$ & $\begin{array}{l}146 \\
0.73 \\
138 \\
5.48 \\
2.7 \\
0.69 \\
0.014\end{array}$ & $\begin{array}{c}4760 \\
31.73 \\
4090 \\
14.08 \\
8.03 \\
27.27 \\
1.67\end{array}$ & $\begin{array}{l}2760 \\
745.95 \\
30.8 \\
98.88 \\
8.46 \\
8.32 \\
3.48\end{array}$ \\
\hline $\begin{array}{l}\text { Filtrate(MF2) } \\
\text { \% Removal } \\
\text { (2ø) } \\
\text { PWQI } \\
\text { (2s) }\end{array}$ & $\begin{array}{l}0.002 \\
51.1 \\
8.3 \\
0.22 \\
0.017\end{array}$ & $\begin{array}{l}<0.02 \\
0 \\
<0.4 \\
0.01\end{array}$ & $\begin{array}{l}<0.038 \\
0\end{array}$ & $\begin{array}{l}0.002 \\
0\end{array}$ & $\begin{array}{c}0.939 \\
99.32 \\
2.76 \\
0.005 \\
7 \times 10^{-5}\end{array}$ & $\begin{array}{l}79.1 \\
98.07 \\
8.62 \\
0.53 \\
0.26\end{array}$ & $\begin{array}{l}45.4^{\circ} \\
7.3 \\
12.26\end{array}$ \\
\hline
\end{tabular}

Note: The water quality indices FWQI and PWQI are defined as a ratio of contaminant concentration in waste feed $(F)$ or in treated filtrate $(P)$ to the maximum allowable concentration of the contaminant under U.S. EPA regulations; 2s: 2 sigms statistics; *: the upper limit of [Cs-137] in the MF1 filtrate and the lower limit of [Cs-137] in the MF2 filtrate are overlapped based on 2s; the values reported can be the same.

1. $\mathrm{Ca}(\mathrm{OH})_{2}(\mathrm{PH}=10.4 ; t=40 \mathrm{~min}$

2. ZEOUTE 1500 pPm; $t=15 \mathrm{minl}$
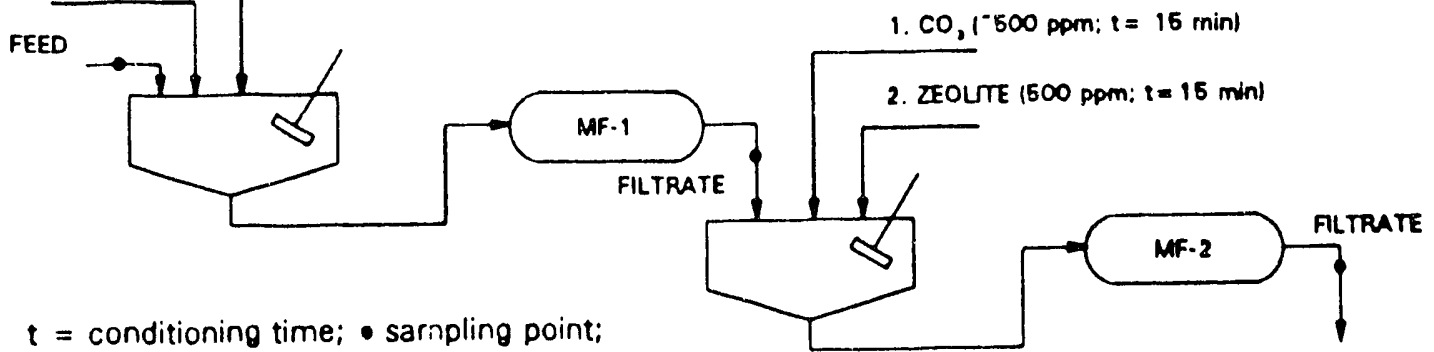

Notes: $\quad t=$ conditioning time; $\bullet$ sarnpling point;

MF = microfiltration 
Table B.6: Single-Slage Poudered Carton Addition.Microflitralloo to Remove Small Amounts of Oranica in the Presence of Heavy Metsle and Radioouclidea (Teal Na. 3i)

\begin{tabular}{|c|c|c|c|c|c|c|c|c|}
\hline $\begin{array}{l}\text { Streim/ } \\
\text { Parimeter }\end{array}$ & [Cd] & $\begin{array}{l}\text { Concenisatio } \\
{[\mathrm{Pb}]}\end{array}$ & $\begin{array}{l}\text { too of Metals } \\
\text { [Fe] }\end{array}$ & $\begin{array}{l}\text { bs if } \mathrm{mg} / \mathrm{hi} \\
\text { [Cal }\end{array}$ & $\begin{array}{l}\text { Redionuclis } \\
\text { [St \&5] }\end{array}$ & $\begin{array}{l}0 \text { is } \mathrm{Bq} / \mathrm{L} \\
{[\mathrm{C} .1377}\end{array}$ & [Beo] & [TCE] \\
\hline $\begin{array}{l}\text { ood } \\
\text { WOI }\end{array}$ & $\begin{array}{l}0.121 \\
12.1\end{array}$ & & $\begin{array}{l}0.063 \\
0.21\end{array}$ & $\begin{array}{l}14.4 \\
0.072\end{array}$ & $\begin{array}{l}310 \\
3.4\end{array}$ & $\begin{array}{l}3050 \\
835.14\end{array}$ & 720 & $520^{26}$ \\
\hline $\begin{array}{l}\text { Utrale } \\
\text { b Removal } \\
\text { 20) } \\
\text { WQI } \\
\text { 2a) }\end{array}$ & $\begin{array}{c}0.0433 \\
64.21 \\
(4.35) \\
4.33 \\
(0.18)\end{array}$ & $\begin{array}{l}<0.021 \\
>80.37 \\
(4.21) \\
<0.42 \\
(0.014)\end{array}$ & $\begin{array}{c}0.0338 \\
46.35 \\
(959) \\
0.1127 \\
(0.009)\end{array}$ & $\begin{array}{c}13.9 \\
3.47 \\
(2.43) \\
0.0695 \\
(0.001)\end{array}$ & $\begin{array}{c}301 \\
40.90 \\
(24.26) \\
2.0 \\
(0.485)\end{array}$ & $\begin{array}{c}930 \\
69.90 \\
(7.99) \\
251.35 \\
(27.57)\end{array}$ & $\begin{array}{c}0.057 \\
98.41 \\
(6.25) \\
11.44 \\
(0.803)\end{array}$ & $\begin{array}{c}0.031 \\
98.82 \\
(8.18) \\
6.14 \\
(0.079)\end{array}$ \\
\hline
\end{tabular}

1. $\mathrm{NaOH}(\mathrm{PH}=9.51$

2. ACTIVATED CARBON $13000 \mathrm{ppm} ; t=1 \mathrm{~N}$

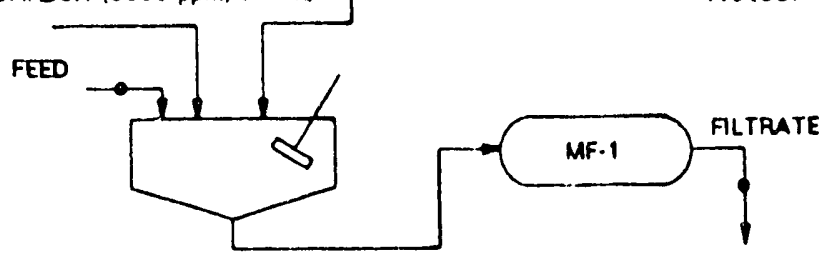

Notes: $\quad t=$ conditioning time; $\bullet$ sampling point; MF = microfiltration

Table B.7: Single-Suge Precipilation Plus Zoolite Addition Followed by Microrituation for the Removal of Sr.90 and Other Metals (rom Groundunter (Teat No. GWA.1)

\begin{tabular}{|c|c|c|c|c|c|c|c|}
\hline \multirow{2}{*}{$\begin{array}{l}\text { Sample Stresm } \\
\text { Calod. Parameter }\end{array}$} & \multicolumn{7}{|c|}{ Metal Concentration (m/ $/ L$ ); Strontium.90 in $\mathrm{Bq} / \mathrm{L}$} \\
\hline & [Cd] & [Pb] & 凹 & [Fe] & [Ca] & [Na] & [Sr-90] \\
\hline $\begin{array}{l}\text { Feed } \\
\text { Aversge } \\
\text { FWOI }\end{array}$ & $\begin{array}{l}0.0067 \\
0.008 \\
0.007 \\
0.7\end{array}$ & $\begin{array}{l}<0.027 \\
<0.027 \\
<0.027 \\
<0.54\end{array}$ & $\begin{array}{l}0.078 \\
0.08 \\
0.079 \\
1.3\end{array}$ & $\begin{array}{c}42.9 \\
42.8 \\
42.85 \\
142.8\end{array}$ & $\begin{array}{l}50.2 \\
50.8 \\
50.5 \\
0.25\end{array}$ & $\begin{array}{l}\mathrm{s08} \\
\mathrm{s08} \\
\mathrm{s08}\end{array}$ & 3260 \\
\hline $\begin{array}{l}\text { Filtrite } \\
\text { \% Removal (PCRE) } \\
\text { PWQI } \\
\text { Fultrate - } \\
\text { \% Removal } \\
\text { PWQI }\end{array}$ & $\begin{array}{l}0.0029 \\
60.5 \\
0.3\end{array}$ & $\begin{array}{l}<0.02 \\
-0 \\
<0.4\end{array}$ & $\begin{array}{c}<0.038 \\
>52.5 \\
<0.6\end{array}$ & $\begin{array}{c}0.044 \\
99.9 \\
0.1\end{array}$ & $\begin{array}{c}3.26 \\
93.5 \\
0.02\end{array}$ & $\begin{array}{l}510 \\
-0\end{array}$ & $\begin{array}{l}72 \\
91.79 \\
205.7 \\
<1 \\
>98.6 \\
<2.8\end{array}$ \\
\hline
\end{tabular}

Note: - Further addition of 200 lite powder $(\$ 000 \mathrm{ppm})$ to the first filtrate removed esentially all Sr.90 present withio detection limit.

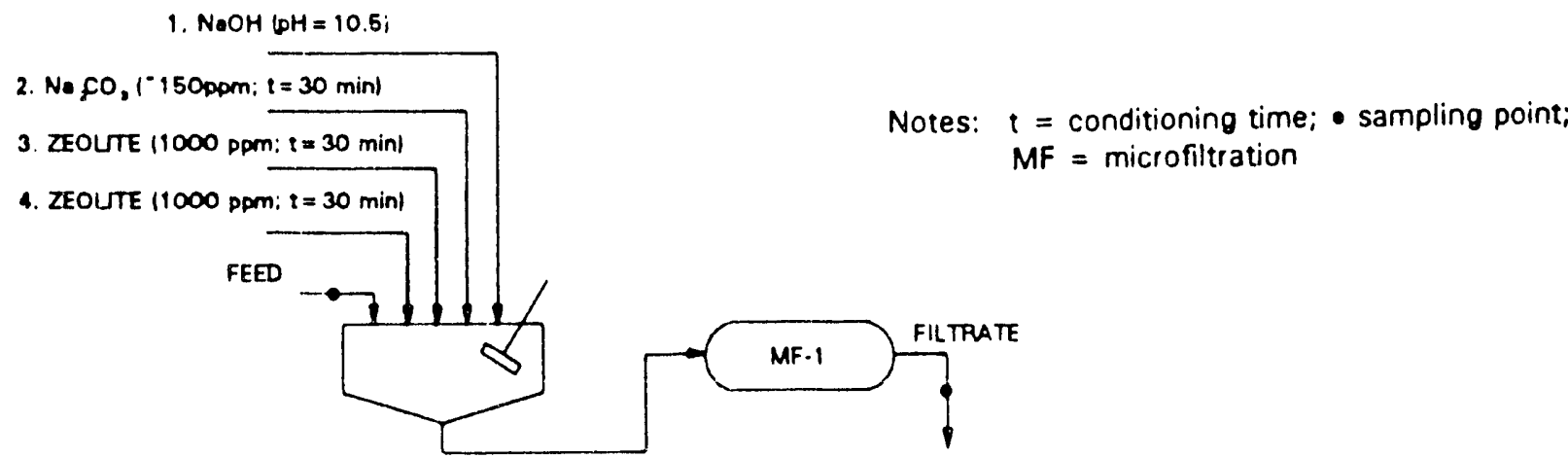


Table B.8: Sequentid Leaching Parametas

\begin{tabular}{|c|c|c|c|}
\hline Stape & Dencriplion & Experimeatal Pa & ders \\
\hline Stage 1 & Len Exchnneable & 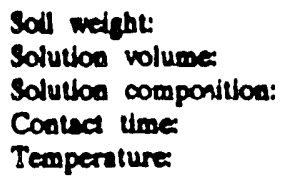 & $\begin{array}{l}0.5 \mathrm{~B} \\
\mathrm{~S} .0 \mathrm{~mL} \\
1 \mathrm{M} \mathrm{MrCh} \\
1 \mathrm{M} \text { (with geatle rolation) } \\
22^{\circ} \mathrm{C}\end{array}$ \\
\hline Stage 2 & $\begin{array}{l}\text { Amorphous } \\
\text { Hydrous Oxides }\end{array}$ & $\begin{array}{l}\text { Sod welght: } \\
\text { Solutton volumes } \\
\text { Solution componition: } \\
\text { Conted time: } \\
\text { Temperature: }\end{array}$ & $\begin{array}{l}0.5 \mathrm{~g} \\
5.0 \mathrm{~mL} \\
0.25 \mathrm{M} \text { Hydrarylamine } \mathrm{HCl}+ \\
0.25 \mathrm{M} \mathrm{HC} \\
0.5 \mathrm{~b} \text { (with seatle rolation) } \\
50^{\circ} \mathrm{C}\end{array}$ \\
\hline Shage 3 & Contalline Fe-Oxides & $\begin{array}{l}\text { Soll weipht: } \\
\text { Solution volume: } \\
\text { Solutioa componition: }\end{array}$ & $\begin{array}{l}0.5 \mathrm{~s} \\
5.0 \mathrm{~mL} \\
0.3 \mathrm{M} \mathrm{Na-dtrite} \\
1 \mathrm{M} \mathrm{NaHCO} \\
\mathrm{Na} \text {-dithionite }\left(\mathrm{Na}_{2} \mathrm{~S}_{2} \mathrm{O}_{4}\right)-18 \\
\text { per rample } \\
0.25 \mathrm{~h} \\
80^{\circ} \mathrm{C}\end{array}$ \\
\hline
\end{tabular}

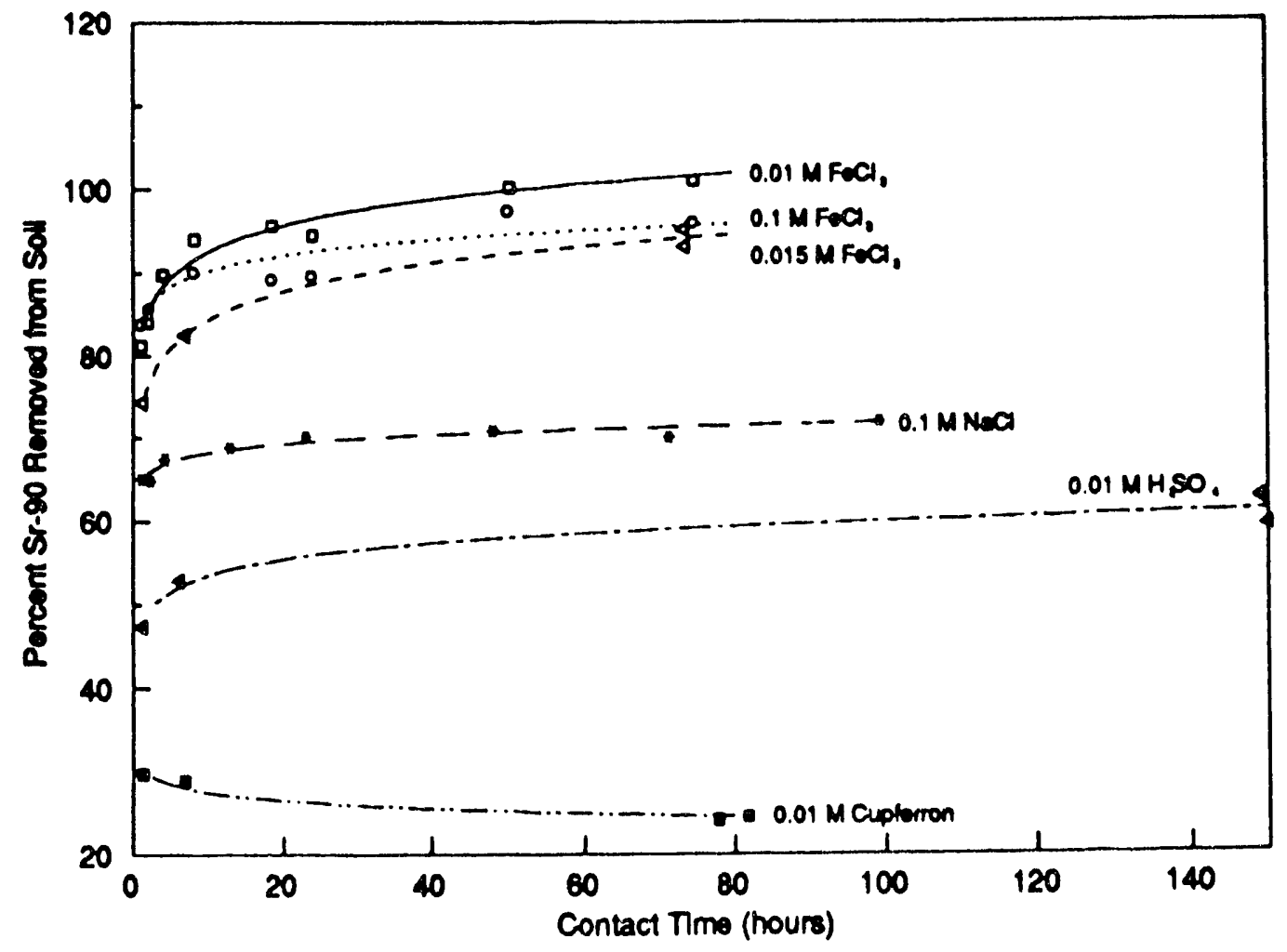

Figure B.1: Percent Sr-90 Removal from Contaminated Soil Leach (Batch) Tests Using Different Leachants 


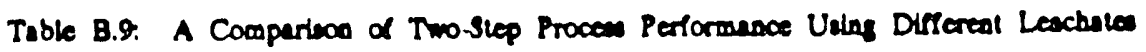

\begin{tabular}{|c|c|c|c|c|c|c|c|c|c|}
\hline \multirow{2}{*}{$\begin{array}{l}\text { Leachnte Fead } \\
\text { Produced by Soll } \\
\text { Washing with }\end{array}$} & \multirow{2}{*}{$\begin{array}{l}\text { Feod } \\
9 r \cdot 90\end{array}$} & \multicolumn{2}{|c|}{$\begin{array}{l}\text { Waler Quallty } \\
\text { (FWOI) }\end{array}$} & \multicolumn{3}{|c|}{$\begin{array}{l}\text { Futrate Quality } \\
\text { (PWOI) }\end{array}$} & \multicolumn{3}{|c|}{$\begin{array}{c}\text { \$ Removil Eftudeacy } \\
\text { (PCRB) }\end{array}$} \\
\hline & & 80 & a & 98.90 & $\mathrm{Pe}$ & $\mathrm{Ca}$ & $3 r .90$ & 80 & Ca \\
\hline $0.01 \mathrm{M} \mathrm{FeCl}_{3}$ & 27714 & 1160 & 0.13 & 2283 & 0.29 & 0.057 & 918 & 99.91 & 57.1 \\
\hline $0.1 \mathrm{M} \mathrm{F} \propto \mathrm{Cl}_{3}$ & 23428 & 17600 & 0.11 & 20 & 0.11 & 0.05 & 99.9 & 99.99 & 523 \\
\hline $10^{-3} \mathrm{M}$ Cupierron & 3714 & 23 & $0.03^{\circ}$ & 283 & 0.065 & $0.04^{\circ}$ & 923 & 99.7 & $0^{\circ}$ \\
\hline $10^{-2} \mathrm{M}$ Cuplerroa & 8857 & 24 & $0.09 \cdots$ & 1100 & 0.06 & $0.10^{\circ}$ & 64.5 & 99.8 & $0 \bullet \cdot$ \\
\hline $0.1 \mathrm{M} \mathrm{H} \mathrm{H}_{2} \mathrm{SO}_{4}$ & 12857 & 1110 & 0.81 & 5142 & 0.07 & 0.25 & 60 & 99.99 & 69.1 \\
\hline
\end{tabular}

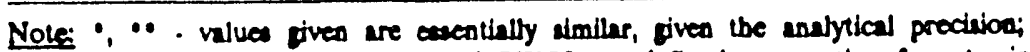

The waier quality indires FWOI and PWOI are definod a a ritho of contaminant concentration in waste foed (F) or in treated filtrate (P) to the maximum allowable concentration of the contaminant under U.S. EPA regulations; 2a: 2 eigme statistica.

Table B.10. A Two-Stage Chemical Trealment.Microfiltration Proceas Perlormance data Showing Strontium.90, Iron and Calcium Removals from Contaminatad Soil Leachate Solution Gexerated Uaing $0.1 \mathrm{M} \mathrm{FeCl}_{3}$ (Teal No. 11B.2)

\begin{tabular}{|c|c|c|c|}
\hline \multirow{2}{*}{ Parameter/Stream } & \multicolumn{3}{|c|}{ Concentritioe ol metal } \\
\hline & $\mathrm{Fe}(m / /)$ & $C_{2}(m g /)$ & $3 r \cdot 90(\mathrm{~Bq} / \mathrm{L})$ \\
\hline $\begin{array}{l}\text { Leachate foed conceatration } \\
\text { (2a) } \\
\text { Food water quality lodes (FWOI) } \\
\text { Stage } 2 \text { filtrite concentrution } \\
\text { (2a) } \\
\text { Pencent removal } \\
\text { (2a) } \\
\text { Filnte water quality index (PWOI) } \\
\text { (2a) }\end{array}$ & $\begin{array}{c}5280 \\
(45.6) \\
17600 \\
0.034 \\
(0.003) \\
-100 \\
(1.2) \\
0.113 \\
(0.009)\end{array}$ & $\begin{array}{l}31.8 \\
(0.58) \\
0.159 \\
10.4 \\
(0.179) \\
67.3 \\
(2.26) \\
0.052 \\
(0.0009)\end{array}$ & $\begin{array}{c}8200 \\
(906.2) \\
27333 \\
7 \\
(2.6) \\
99.9 \\
(15.62) \\
23.33 \\
(8.78)\end{array}$ \\
\hline
\end{tabular}

Note: The water quality indices FWQI and PWQI are defined as a ratio of contaminant concentration in waste feed $(F)$ or in treated filtrate $(P)$ to the marimum alfowable concentration of the contaminant under U.S. EPA regulations; 2a: 2 sigms statistica.

1. $\mathrm{N} O \mathrm{OH}(6 \mathrm{H}=9.6 ; ?=4 \mathrm{~h})$

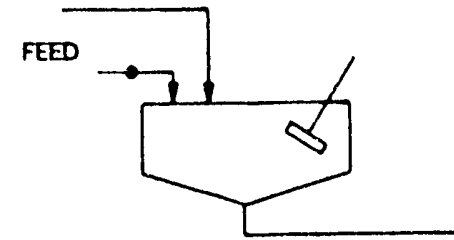

Notes: $\quad t=$ conditioning time; $\bullet$ sampling point;

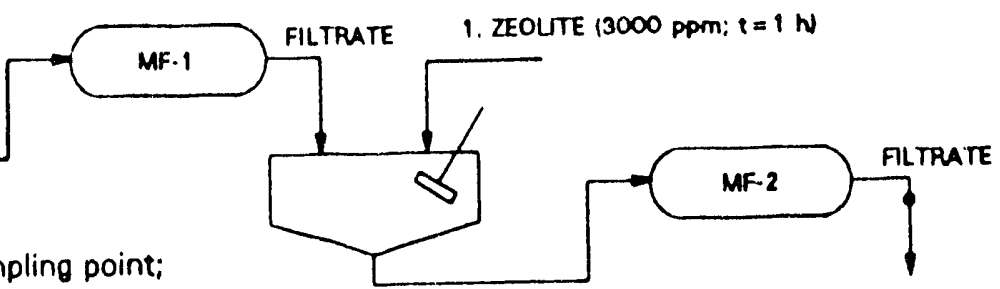
MF = microfiltration 


\section{APPENDIX C - PILOT-SCALE TEST RESULTS}

Table C. 1: Pilo-Scale Tea Results for Contaminant Removal Using a Sequential Three-Step Process livolving PrecipitationMicrofiliration (Tes No. SLZ1)

\begin{tabular}{|c|c|c|c|c|c|c|c|c|c|c|}
\hline \multirow{2}{*}{$\begin{array}{l}\text { Description } \\
\text { of Stream/ } \\
\text { Parameter }\end{array}$} & \multicolumn{6}{|c|}{$\begin{array}{l}\text { Concentration of Metals and Organics in } \mathrm{mg} / \mathrm{L} ; \\
\text { Concentration of Radionuclides in } \mathrm{Bq} / \mathrm{L}\end{array}$} & \multirow[b]{2}{*}[5r-85]{} & \multirow[b]{2}{*}[\mathrm{Cz}-137]{} & \multirow[b]{2}{*}{ [Ben] } & \multirow[b]{2}{*}{ [TCE] } \\
\hline & {$[\mathrm{Cd}]$} & {$[\mathrm{Pb}]$} & [U] & {$[\mathrm{Fe}]$} & [Ca] & {$[\mathrm{Na}]$} & & & & \\
\hline $\begin{array}{l}\text { Feed } \\
\text { (28) } \\
\text { FWQI }\end{array}$ & $\begin{array}{l}1.66 \\
(0.034) \\
166\end{array}$ & $\begin{array}{c}9.56 \\
(0.269) \\
191.2\end{array}$ & $\begin{array}{l}1.72 \\
(0.072) \\
28.66\end{array}$ & $\begin{array}{l}46.8 \\
(1.003) \\
156\end{array}$ & $\begin{array}{l}146 \\
(2.866) \\
0.73\end{array}$ & $\begin{array}{l}0.077 \\
(0.0023)\end{array}$ & $\begin{array}{r}4310 \\
(215.5) \\
28.73\end{array}$ & $\begin{array}{l}3310 \\
(165.5) \\
894.6\end{array}$ & $\begin{array}{l}13.1 \\
(0.506) \\
2620\end{array}$ & $\begin{array}{c}15.7 \\
(0.976) \\
3140\end{array}$ \\
\hline $\begin{array}{l}\text { Process Ste } \\
\text { Filtrate } \\
(28)\end{array}$ & $\begin{array}{c}0.0018 \\
(0.0001)\end{array}$ & $\begin{array}{l}0.021 \\
(0.0007)\end{array}$ & $\begin{array}{l}0.038 \\
(0.0042)\end{array}$ & $\begin{array}{l}0.02 \\
(0.0019)\end{array}$ & $\begin{array}{l}133 \\
(2.60)\end{array}$ & $\begin{array}{l}6.86 \\
(0.15)\end{array}$ & $\begin{array}{l}3020 \\
(151)\end{array}$ & $\begin{array}{l}32.7 \\
(1.96)\end{array}$ & $\begin{array}{l}9.8 \\
(0.391)\end{array}$ & $\begin{array}{l}10.5 \\
(0.643)\end{array}$ \\
\hline $\begin{array}{l}\text { Process Ste } \\
\text { Filtrate } \\
(2 s)\end{array}$ & $\begin{array}{c}0.0018 \\
(0.0001)\end{array}$ & $\begin{array}{l}0.021 \\
(0.0007)\end{array}$ & $\begin{array}{l}0.038 \\
(0.0042)\end{array}$ & $\begin{array}{l}0.03 \\
(0.001)\end{array}$ & $\begin{array}{l}1.3 \\
(0.026)\end{array}$ & $\begin{array}{l}221 \\
(3.8)\end{array}$ & $\begin{array}{l}18.9 \\
(1.51)\end{array}$ & $\begin{array}{l}17.8 \\
(1.6)\end{array}$ & $\begin{array}{l}7 \\
(0.29)\end{array}$ & $\begin{array}{c}6.6 \\
(0.4)\end{array}$ \\
\hline $\begin{array}{l}\text { Process Ste } \\
\text { Filtrate } \\
(2 s)\end{array}$ & $\begin{array}{c}0.0018 \\
(0.0001)\end{array}$ & $\begin{array}{l}0.021 \\
(0.0007)\end{array}$ & $\begin{array}{l}0.038 \\
(0.0042)\end{array}$ & $\begin{array}{c}0.009 \\
(0.0010)\end{array}$ & $\begin{array}{l}1.0 \\
(0.015)\end{array}$ & $\begin{array}{l}211 \\
(3.64)\end{array}$ & $\begin{array}{l}12.6 \\
(1.26)\end{array}$ & $\begin{array}{l}25.7 \\
(1.8)\end{array}$ & $\begin{array}{l}0.076 \\
(0.005)\end{array}$ & $\begin{array}{c}0.159 \\
(0.008)\end{array}$ \\
\hline $\begin{array}{l}\text { Process Step } \\
\text { O Removal } \\
\text { (2s) } \\
\text { PWQI } \\
(2 s)\end{array}$ & $\begin{array}{c}+2: \\
99.89 \\
(2.87) \\
0.18 \\
(0.014)\end{array}$ & $\begin{array}{c}99.78 \\
(3.97) \\
0.42 \\
(0.014)\end{array}$ & $\begin{array}{c}97.79 \\
(5.88) \\
0.63 \\
(0.071)\end{array}$ & $\begin{array}{c}99.93 \\
(3.03) \\
0.1 \\
(0.008)\end{array}$ & $\begin{array}{l}99.1 \\
(2.76) \\
0.006 \\
(0.0001)\end{array}$ & & $\begin{array}{c}99.56 \\
(7.06) \\
0.126 \\
(0.01)\end{array}$ & $\begin{array}{l}99.46 \\
(7.05) \\
4.8 \\
(0.433)\end{array}$ & $\begin{array}{c}46.56 \\
(4.80) \\
1400 \\
(58)\end{array}$ & $\begin{array}{l}57.96 \\
(7.62) \\
1320 \\
(79.5)\end{array}$ \\
\hline $\begin{array}{l}\text { Overail: Pro } \\
\text { ORemoval } \\
\text { (2s) } \\
\text { PWQI } \\
\text { (2\&) }\end{array}$ & $\begin{array}{c}\text { Steps } 1 \\
99.89 \\
(2.87) \\
0.18 \\
(0.014)\end{array}$ & $\begin{array}{c}2+3: \\
99.78 \\
(3.97) \\
0.42 \\
(0.014)\end{array}$ & $\begin{array}{l}97.79 \\
(5.88) \\
0.63 \\
(0.071)\end{array}$ & $\begin{array}{c}99.98 \\
(3.03) \\
0.03 \\
(0.003)\end{array}$ & $\begin{array}{l}99.3 \\
(2.77) \\
0.005 \\
(0.0001)\end{array}$ & & $\begin{array}{c}99.7 \\
(11.30) \\
0.084 \\
(0.008)\end{array}$ & $\begin{array}{c}99.22 \\
(12.68) \\
6.95 \\
(0.486)\end{array}$ & $\begin{array}{l}99.42 \\
(5.45) \\
15.2 \\
(1.037)\end{array}$ & $\begin{array}{l}99.98 \\
(8.75) \\
31.8 \\
(1.673)\end{array}$ \\
\hline
\end{tabular}

Note: The water quality indices FWQI and PWQI are defined as a ratio of contaminant concentration in waste feed (F) or in treated filtrate $(P)$ to the maximum allowable concentration of the contaminant in drinking water under U.S. EPA regulations; 2s: 2 sigma statistics; the increase in Cs-137 from Step 2 to Step 3 is likely due to cross contamination.

1. $C_{D}(O H),(200$ pprn; $p H=11.2 ; t=0.5 \mathrm{~h})$

2. ZEOLITE $11000 \mathrm{pPm}: \mathrm{l}=0.5 \mathrm{~h})$

FEED

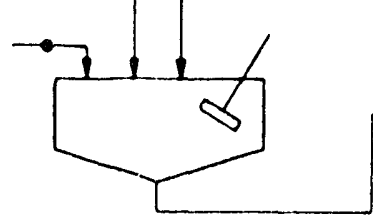

1. No $, \mathrm{CO}, 1500 \mathrm{ppm} ; \mathrm{pH}=10.7: \mathrm{t}=0.5 \mathrm{hl}$

2. ZEOUTE $(1000 \mathrm{ppm} ; t=0.5 \mathrm{~h})$

3. ZEOLITE $(1000$ ppm; $t=0.5 \mathrm{hl}$

FILTRATE

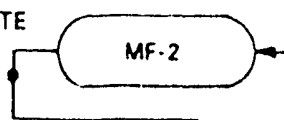

1. ACTIVATED CARBON

$(p H=105: 1000 \mathrm{ppm} ;:=0.5 \mathrm{~h})$

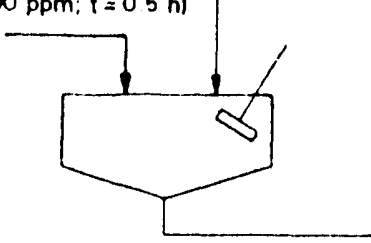

Notes: $\quad I=$ conditioning time; $\bullet$ sampling point; MF = microfiltration 
Table C.2: Pilot-Scale Tea Results for Contaminant Removal Using a Sequential Three-Step Process Involving Precipilation-Microfiltration (Tea No. SLZ2)

\begin{tabular}{|c|c|c|c|c|c|c|c|c|c|c|}
\hline \multirow{2}{*}{$\begin{array}{l}\text { Description } \\
\text { of Stream/ } \\
\text { Parameter }\end{array}$} & \multicolumn{7}{|c|}{$\begin{array}{l}\text { Concentration of Metals and Organics in } \mathrm{mg} / \mathrm{L} ; \\
\text { Concentration of Radionuclides in } \mathrm{Bq} / \mathrm{L}\end{array}$} & \multirow[b]{2}{*}[C8-137]{} & \multirow[b]{2}{*}[\mathrm{Ben}]{} & \multirow[b]{2}{*}[\mathrm{TCE}]{} \\
\hline & [Cd] & {$[\mathrm{Pb}]$} & |U] & $|\mathrm{Fe}|$ & [Ca] & {$[\mathrm{Na}]$} & {$[\mathrm{Sr}-85]$} & & & \\
\hline $\begin{array}{l}\text { Feed } \\
\text { (2s) } \\
\text { FWQI }\end{array}$ & $\begin{array}{l}10.7 \\
(0.15) \\
1070\end{array}$ & $\begin{array}{c}34.1 \\
(0.92) \\
682\end{array}$ & $\begin{array}{c}4.3 \\
(0.14) \\
71.66\end{array}$ & $\begin{array}{r}46.3 \\
(0.99) \\
154.3\end{array}$ & $\begin{array}{c}143 \\
(2.80) \\
0.71\end{array}$ & $\begin{array}{c}0.044 \\
(0.0014)\end{array}$ & $\begin{array}{c}17300 \\
(865) \\
115.3\end{array}$ & $\begin{array}{l}15100 \\
(755) \\
4081\end{array}$ & $\begin{array}{l}13.1 \\
(0.5) \\
2620\end{array}$ & $\begin{array}{l}13.8 \\
(0.85) \\
2760\end{array}$ \\
\hline $\begin{array}{l}\text { Process Step } \\
\text { Filtrate } \\
\text { (2s) }\end{array}$ & $\begin{array}{r}0.0064 \\
(0.0004)\end{array}$ & $\begin{array}{r}0.034 \\
(0.001)\end{array}$ & $\begin{array}{c}0.038 \\
(0.004)\end{array}$ & $\begin{array}{c}0.016 \\
(0.0016)\end{array}$ & $\begin{array}{c}129 \\
(2.52)\end{array}$ & $(0.161)$ & $\begin{array}{l}12700 \\
(635)\end{array}$ & $\begin{array}{r}98.8 \\
(4.94)\end{array}$ & $\begin{array}{r}10.3 \\
(0.41)\end{array}$ & $\begin{array}{c}9.9 \\
(0.61)\end{array}$ \\
\hline $\begin{array}{l}\text { Process Step } \\
\text { Filtrale } \\
(2 s)\end{array}$ & $\begin{array}{r}0.016 \\
(0.0008)\end{array}$ & $\begin{array}{c}0.02 \\
(0.0007)\end{array}$ & $\begin{array}{c}0.038 \\
(0.004)\end{array}$ & $\begin{array}{r}0.0023 \\
(0.0003)\end{array}$ & $\begin{array}{r}1.64 \\
(0.026)\end{array}$ & $\begin{array}{l}211 \\
(3.64)\end{array}$ & $\begin{array}{c}135 \\
(6.75)\end{array}$ & $\begin{array}{r}48 \\
(2.4)\end{array}$ & $\begin{array}{c}6.6 \\
(0.28)\end{array}$ & $\begin{array}{c}5.7 \\
(0.34)\end{array}$ \\
\hline $\begin{array}{l}\text { Process Sted } \\
\text { Filirate } \\
(2 \mathrm{~s})\end{array}$ & $\begin{array}{c}0.101 \\
(0.0036)\end{array}$ & $\begin{array}{r}0.031 \\
(0.001)\end{array}$ & $\begin{array}{r}0.038 \\
(0.004)\end{array}$ & $\begin{array}{r}0.0023 \\
(0.0003)\end{array}$ & $\begin{array}{r}9.93 \\
(3.56)\end{array}$ & $\begin{array}{l}206 \\
(3.56)\end{array}$ & $\begin{array}{r}68.4 \\
(3.42)\end{array}$ & $\begin{array}{l}13.7 \\
(1.37)\end{array}$ & $\begin{array}{r}0.0761 \\
(0.0052)\end{array}$ & $\begin{array}{l}0.1158 \\
(0.006)\end{array}$ \\
\hline $\begin{array}{l}\text { Process Siep } \\
\text { \% Removal } \\
\text { (2s) } \\
\text { PWQI } \\
(2 s)\end{array}$ & $\begin{array}{c}1+2: \\
99.85 \\
(1.98) \\
1.6^{\circ} \\
(0.082)\end{array}$ & $\begin{array}{c}99.94 \\
(3.82) \\
0.4 \\
(0.014)\end{array}$ & $\begin{array}{c}99.12 \\
(4.6) \\
0.63 \\
(0.071)\end{array}$ & $\begin{array}{c}99.99 \\
(3.04) \\
0.007 \\
(0.0011)\end{array}$ & $\begin{array}{c}98.85 \\
(2.76) \\
0.008 \\
(0.0001)\end{array}$ & & $\begin{array}{c}99.22 \\
(7.04) \\
0.9 \\
(0.045)\end{array}$ & $\begin{array}{c}99.68 \\
(7.06) \\
12.97 \\
(0.65)\end{array}$ & $\begin{array}{l}49.6 \\
(4.8) \\
1320 \\
(55)\end{array}$ & $\begin{array}{l}58.69 \\
(7.6) \\
1140 \\
(68.3)\end{array}$ \\
\hline $\begin{array}{l}\text { Overall: Proo } \\
\text { O Removal } \\
\text { (2s) } \\
\text { PWQI } \\
(2 s)\end{array}$ & $\begin{array}{c}\text { ss Stegs } 1 \\
99.06 \\
(1.97) \\
10.1 * \\
(0.36)\end{array}$ & $\begin{array}{c}2+3: \\
99.9 \\
(3.82) \\
0.62 * \\
(0.02)\end{array}$ & $\begin{array}{c}99.1 \\
(4.68) \\
0.63 \\
(0.071)\end{array}$ & $\begin{array}{c}99.99 \\
(3.04) \\
0.007 \\
(0.001)\end{array}$ & $\begin{array}{c}93.1 \\
(2.68) \\
0.005 \\
(0.0009)\end{array}$ & & $\begin{array}{c}99.6 \\
(7.06) \\
0.45 \\
(0.0228)\end{array}$ & $\begin{array}{c}99.9 \\
(7.06) \\
3.7 \\
(0.37)\end{array}$ & $\begin{array}{c}99.42 \\
(5.45) \\
15.2 \\
(1.04)\end{array}$ & $\begin{array}{c}99.16 \\
(8.72) \\
23.2 \\
(1.2)\end{array}$ \\
\hline
\end{tabular}

Note: - The relatively high concenliation values for cadmium, lead and calcium in the fillrate were due to redissolution of metals potentially trapped in the equipment loop when the solution pH was reduced from 11.2 to 7.4, which resulted in the passage of metal ions through the microfilter and ended up in the filtrate stream; the water quality indices FWQI and PWQI are defined as a ratio of contaminant concentration in waste feed $(F)$ or in trealed filtrate (P) to maximum allowable concentration of the contaminant in drinking water under U.S. EPA regulations; 2s: 2 sigma statistics.

1. $\mathrm{C}:(\mathrm{OH}),(200 \mathrm{ppm} ; \mathrm{pH}=11,3 ; t=0.5 \mathrm{~h}$

2. ZEOLITE 11000 pprn: $:=0.5 \mathrm{~W}$

FEED

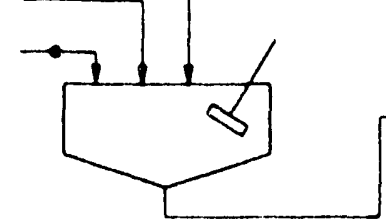

1. $\mathrm{N} \cdot \mathrm{fO},(500 \mathrm{ppm} ; \mathrm{pH}=|1.2: \mathrm{t}=0.5 \mathrm{~h}\rangle$

2. ZEOUTE $(1000 \mathrm{pPm} ; \mathrm{t}=0.5 \mathrm{hl}$

3. ZEOLITE $(1000$ pprn, $t=05 \mathrm{~h})$

FILTRATE

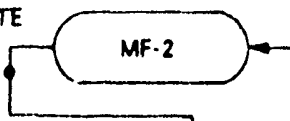

1. $\mathrm{HCl}(\mathrm{pH}=7: t=10 \mathrm{~min})$

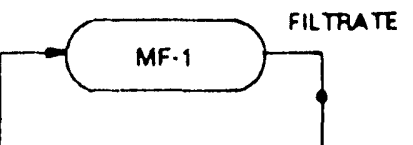

2. ACTIVATED CARBON \& ZEOUTE

$11000 \mathrm{ppm} ; 1000 \mathrm{ppm} ; \mathrm{t}=0.5 \mathrm{~h})$

3. ZEOUTE $(1000 \mathrm{ppm} ; \mathrm{t}=05 \mathrm{~h})$
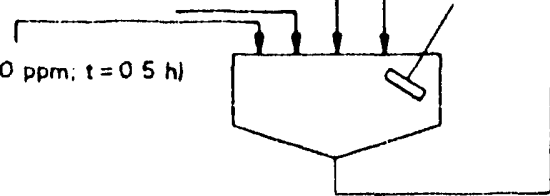
Table C.3: Pilo-Scale Teat Results for Contaminant Removal Using a Sequential Three-Step Procese Involving Chemical Treatment-Microfiltration (Tea No. SLZ4)

\begin{tabular}{|c|c|c|c|c|c|c|c|c|c|c|}
\hline \multirow{2}{*}{$\begin{array}{l}\text { Deacription } \\
\text { of Stream/ } \\
\text { Parnmeter }\end{array}$} & \multicolumn{10}{|c|}{$\begin{array}{l}\text { Concentration of Metals and Organics in mg/L } \\
\text { Concentration of Radionuclides in Bq/L }\end{array}$} \\
\hline & [Cd] & {$[\mathrm{Pb}]$} & [U] & [Fe] & [Ca] & [Na] & [Sr-85] & {$[\mathrm{Cs}-137]$} & [Ben] & [TCE] \\
\hline $\begin{array}{l}\text { Feed } \\
(28) \\
\text { FWQI }\end{array}$ & $\begin{array}{c}1.78 \\
(0.036) \\
178\end{array}$ & $\begin{array}{c}6.13 \\
(0.175) \\
122.6\end{array}$ & $\begin{array}{r}1.80 \\
(0.075) \\
30.00\end{array}$ & $\begin{array}{c}0.6 \\
(1.07) \\
168.67\end{array}$ & $\begin{array}{c}154 \\
(3.03) \\
0.77\end{array}$ & $\begin{array}{r}0.065 \\
(0.002)\end{array}$ & $\begin{array}{r}6180 \\
(3.09) \\
41.2\end{array}$ & $\begin{array}{c}3190 \\
(159.5) \\
862.16\end{array}$ & $\begin{array}{l}7.4 \\
(0.31) \\
1480\end{array}$ & $\begin{array}{c}4.9 \\
(0.29) \\
980\end{array}$ \\
\hline $\begin{array}{l}\text { Process Step } \\
\text { Filtrate } \\
\text { (2s) }\end{array}$ & $\begin{array}{r}0.0018 \\
(0.0001)\end{array}$ & $\begin{array}{r}0.021 \\
(0.0007)\end{array}$ & $\begin{array}{r}0.039 \\
(0.004)\end{array}$ & $\begin{array}{r}0.019 \\
(0.0018)\end{array}$ & $\begin{array}{l}134 \\
(0.62)\end{array}$ & $\begin{array}{c}9.55 \\
(0.205)\end{array}$ & $\begin{array}{l}4100 \\
(205)\end{array}$ & $\begin{array}{r}76.1 \\
(3.81)\end{array}$ & $\begin{array}{c}6.1 \\
(0.26)\end{array}$ & $\begin{array}{c}4.0 \\
(0.24)\end{array}$ \\
\hline $\begin{array}{l}\text { Proceas Step } \\
\text { Filtrate }\end{array}$ & 0.0018 & 0.021 & 0.039 & 0.015 & 2.05 & 230 & 21.5 & 8.06 & 3.8 & 2.1 \\
\hline $\begin{array}{l}\text { Proceas Step } \\
\text { Filtrale } \\
(2 \triangleleft)\end{array}$ & $\begin{array}{r}0.0018 \\
(0.0001)\end{array}$ & $\begin{array}{r}0.021 \\
(0.0007)\end{array}$ & $\begin{array}{r}0.039 \\
(0.004)\end{array}$ & $\begin{array}{r}0.0086 \\
(0.0010)\end{array}$ & $\begin{array}{c}2.16 \\
(0.034)\end{array}$ & $\begin{array}{l}220 \\
(3.78)\end{array}$ & $\begin{array}{c}3.5 \\
(0.175)\end{array}$ & $\begin{array}{c}3.48 \\
(0.174)\end{array}$ & $\begin{array}{c}0.0624 \\
(0.0043)\end{array}$ & $\begin{array}{r}0.0837 \\
(0.0043)\end{array}$ \\
\hline $\begin{array}{l}\text { Process Slep } \\
\text { \% Removal } \\
\text { (2s) } \\
\text { PWQI } \\
\text { (2s) }\end{array}$ & $\begin{array}{c}1+2: \\
99.90 \\
(2.83) \\
0.18 \\
(0.014)\end{array}$ & $\begin{array}{c}99.66 \\
(4.03) \\
0.42 \\
(0.014)\end{array}$ & $\begin{array}{c}97.83 \\
(5.81) \\
0.65 \\
(0.071)\end{array}$ & $\begin{array}{c}99.97 \\
(2.98) \\
0.05 \\
(0.005)\end{array}$ & $\begin{array}{c}98.67 \\
(2.7) \\
0.01 \\
(0.0001)\end{array}$ & $\begin{array}{l}\text { NA } \\
\text { NA }\end{array}$ & $\begin{array}{c}99.65 \\
(7.06) \\
0.143 \\
(0.007)\end{array}$ & $\begin{array}{c}99.75 \\
(7.06) \\
2.17 \\
(0.109)\end{array}$ & $\begin{array}{c}48.65 \\
(5.11) \\
760 \\
(33.66)\end{array}$ & $\begin{array}{c}57.14 \\
(7.29) \\
420 \\
(24.2)\end{array}$ \\
\hline $\begin{array}{l}\text { Overall: Pro } \\
\text { D Removal } \\
\text { (2ø) } \\
\text { PWQI } \\
\text { (2s) }\end{array}$ & $\begin{array}{c}\text { Sicps } 1 \\
99.90 \\
(2.83) \\
0.18 \\
(0.014)\end{array}$ & $\begin{array}{c}+2+3: \\
99.66 \\
(4.03) \\
0.42 \\
(0.014)\end{array}$ & $\begin{array}{c}97.83 \\
(5.81) \\
0.65 \\
(0.071)\end{array}$ & $\begin{array}{c}99.98 \\
(2.98) \\
0.029 \\
(0.0032)\end{array}$ & $\begin{array}{c}98.60 \\
(2.76) \\
0.01 \\
(0.0002)\end{array}$ & $\begin{array}{l}\text { NA } \\
\text { NA }\end{array}$ & $\begin{array}{c}99.94 \\
(7.07) \\
0.023 \\
(0.0012)\end{array}$ & $\begin{array}{r}99.89 \\
(7.07) \\
0.94 \\
(0.047)\end{array}$ & $\begin{array}{c}99.16 \\
(5.8) \\
12.48 \\
(0.869)\end{array}$ & $\begin{array}{c}98.29 \\
(8.35) \\
16.74 \\
(0.858)\end{array}$ \\
\hline
\end{tabular}

Note: The water quality indices FWQI and PWQI are defined as a ratio of contaminant concentration in waste feed (F) or in treated filtrate (P) to the maximum allowable concentration of the contaminant in drinking water under U.S. EPA regulations; 2s: 2 sigma statistics.

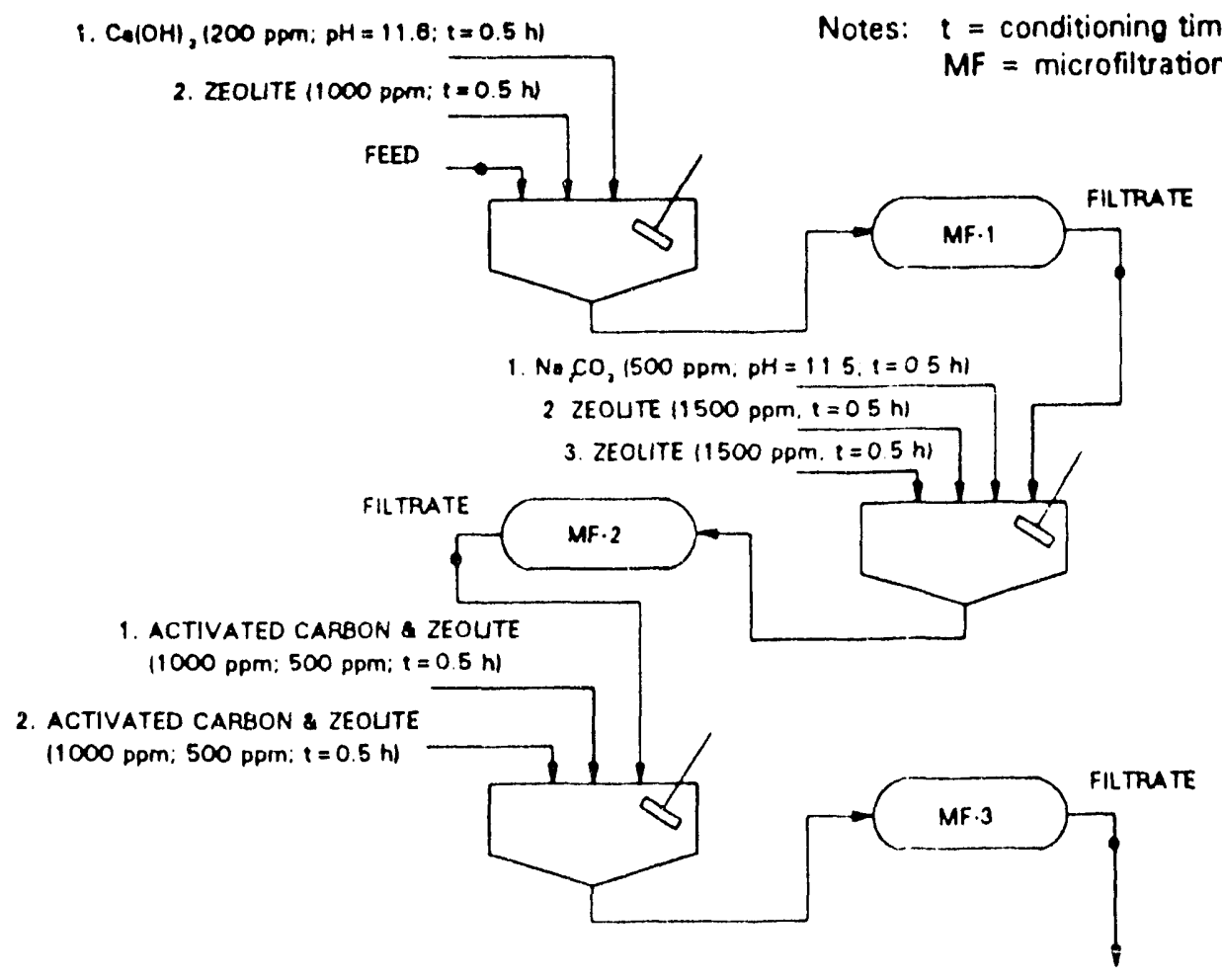


Table C.4: A Twasuge Chemical Treatmeal.Mlcrofituntion Procew Performasce Dats Showing Stroollum.90 Recooval iroed Groundwiter as. Function of Waste Volume Roduced (Tell No. WMAB.2)

\begin{tabular}{lc}
\hline Strenm/Panmelar & \\
\hline Feed concentration of (Sr.90 Bq/L) & 2100 \\
(2a) & $(293.9)$ \\
Foed water quality index (FWOI) & 7000 \\
Stage 2 filtrite concentrition (Sr.90 Bq/L) & 8 \\
(2a) & $(2.9)$ \\
Percent Sr 90 removal & 99.62 \\
(2a) & $(19.74)$ \\
Filtrate water quality iadex (PWOI) & 26.6 \\
(2a) & $(9.45)$
\end{tabular}

Note: The water quality indices FWQI and PWOI are defined as a ratio of contsminant concentration in wate food (F) of in treated filtrate $(P)$ to the meximum allowable concentration $\alpha$ the contaminant is drinking water under U.S. EPA regulatioas; 2a: 2 sigme statistica.

1. $\mathrm{N} \odot \mathrm{OH}(\mathrm{PH}=9.6 ; t=4 \mathrm{hI}$

FEED

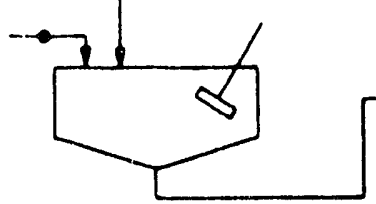

Notes: $t=$ conditioning time; $\bullet$ sampling point:

MF.1 FILTPUTE 1. ZEOLITE 15000 pPm; $t=2 \mathrm{~W}$ MF = microfiltration

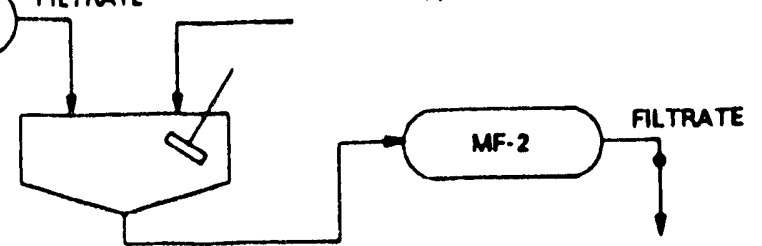


Table C.5: Pilo-Scale Test Resulta for Contaminant Removal Using a Sequential Three-Step Process l.ıvolving PrecipitationMicrofiltration (Process Step 1), Zeolite Ion Exchange-Microfiltration (Process Slep 2) and Activated Carbon Adsorption-Microfiltration (Process Step 3) with a Waste feed Consisting of Groundwater from Area "B" at CRL Spiked with Metal Contaminants, Radionuclides and Organics; Temperature of Operation: $-15^{\circ} \mathrm{C}$; (Teat No. 16E.2)

$\begin{array}{lc}\text { Dewcription of } & \text { Concentration of Mets/s and Organics in } \mathrm{mg} / \mathrm{L} \\ \text { Stream/Parameler } & \text { Concentration of Radionuclides in Bq/L }\end{array}$

\begin{tabular}{|c|c|c|c|c|c|c|c|c|c|}
\hline & {$[\mathrm{Cd}]$} & {$[\mathrm{Pb}]$} & $|\mathrm{Fe}|$ & {$[\mathrm{Ca} \mid$} & {$[\mathrm{Sr}-85]$} & {$[\mathrm{Sr}-90]$} & {$\left[\mathrm{Cs}_{\mathrm{S}}-137\right]$} & [Benzene] & [TCE] \\
\hline $\begin{array}{l}\text { Feed } \\
\text { (2s) } \\
\text { FWQI }\end{array}$ & $\begin{array}{l}2.47 \\
(0.046) \\
247\end{array}$ & $\begin{array}{c}8.96 \\
(0.252) \\
179.2\end{array}$ & $\begin{array}{c}68.4 \\
(1.36) \\
228\end{array}$ & $\begin{array}{r}71.1 \\
(1.35) \\
0.36\end{array}$ & $\begin{array}{c}2012.8 \\
(134) \\
13.6\end{array}$ & $\begin{array}{c}5420 \\
(643.5) \\
15485\end{array}$ & $\begin{array}{c}10500 \\
(579) \\
2838\end{array}$ & & \\
\hline $\begin{array}{l}\text { Process Step 1: } \\
\text { Filinate } \\
\text { (20) }\end{array}$ & $\begin{array}{c}0.0055 \\
(0.0007)\end{array}$ & $\begin{array}{r}<0.02 \\
(0.0007)\end{array}$ & $\begin{array}{c}0.007 \\
(0.008)\end{array}$ & $\begin{array}{c}3.34 \\
(0.054)\end{array}$ & $\begin{array}{c}152.1 \\
(53.1)\end{array}$ & & $\begin{array}{c}1853.7 \\
(114.3)\end{array}$ & & \\
\hline $\begin{array}{l}\text { Process Step 2: } \\
\text { Filtrate } \\
(2 s)\end{array}$ & $\begin{array}{c}0.0048 \\
0.003)\end{array}$ & $\begin{array}{r}<0.02 \\
(0.0007)\end{array}$ & $\begin{array}{r}0.01 \\
(0.001)\end{array}$ & $\begin{array}{c}5.18 \\
(0.086)\end{array}$ & $\begin{array}{r}28.3 \\
(24.5)\end{array}$ & $\begin{array}{r}82.7 \\
(20.3)\end{array}$ & $\begin{array}{r}74 \\
(22.2)\end{array}$ & NA & NA \\
\hline $\begin{array}{l}\text { Process Step 3: } \\
\text { Feed" } \\
\text { Filirate } \\
\text { (28) }\end{array}$ & $\begin{array}{r}0.0025 \\
(0.0002)\end{array}$ & $\begin{array}{r}<0.02 \\
(0.0007)\end{array}$ & $\begin{array}{r}0.007 \\
(0.0007)\end{array}$ & $\begin{array}{r}6.32 \\
(0.11)\end{array}$ & $\begin{array}{r}28.3 \\
(24.5)\end{array}$ & $\begin{array}{r}82.7 \\
(20.3)\end{array}$ & $\begin{array}{r}74 \\
(22.2)\end{array}$ & $\begin{array}{c}2.3(2 \mathrm{~s}=0.1 \\
0.003 \\
(0.0003)\end{array}$ & $\begin{array}{l}0.791(0.044) \\
0.0012 \\
(0.00005)\end{array}$ \\
\hline
\end{tabular}

\begin{tabular}{lccccccc}
\hline Process Slipg 1+2: & & & & & & \\
O Removal & 99.8 & $>99.8$ & 99.99 & 92.7 & 98.5 & 98.5 & 99.3 \\
(2s) & $(2.65)$ & $(3.98)$ & $(2.82)$ & $(2.59)$ & $(9.43)$ & $(16.7)$ & $(7.77)$ \\
PWQI & 0.48 & $<0.4$ & 0.03 & 0.03 & 0.2 & 236.3 & 20 \\
$(28)$ & $(0.31)$ & $(0.014)$ & $(0.004)$ & $(0.0004)$ & $(0.16)$ & $(67.6)$ & $(6.0)$
\end{tabular}

\begin{tabular}{lccccccccc}
\hline Overall: Process Steps $1+2+3:$ & & & & & & & \\
\hline ORemoval & 99.9 & $>99.8$ & 99.99 & 91 & 98.5 & 98.5 & 99.3 & 99.9 & 99.8 \\
$(2 \mathrm{~s})$ & $(2.65)$ & $(3.98)$ & $(2.82)$ & $(2.57)$ & $(9.4)$ & $(16.7)$ & $(7.7)$ & $(6.6)$ & $(7.9)$ \\
PWQ1 & 0.25 & $<0.4$ & 0.02 & 0.03 & 0.2 & 236.3 & 20 & 0.6 & 0.2 \\
$(2 \mathrm{~s})$ & $(0.019)$ & $(0.014)$ & $(0.002)$ & $(0.0005)$ & $(0.16)$ & $(67.6)$ & $(6.0)$ & $(0.06)$ & $(0.01)$
\end{tabular}

Note: The water quality indices FWQI and PWQI are defined as a ratio of contaminant concentration in waste feed (F) or in treated filtrale (P) to the maximum allowable concentration of the contaminant in drinking water under U.S. EPA regulations; $28: 2$ sigma statistics;

- feed to process step 13 is the same as fillrate from step 2 except that the filtrate was spiked with organics.

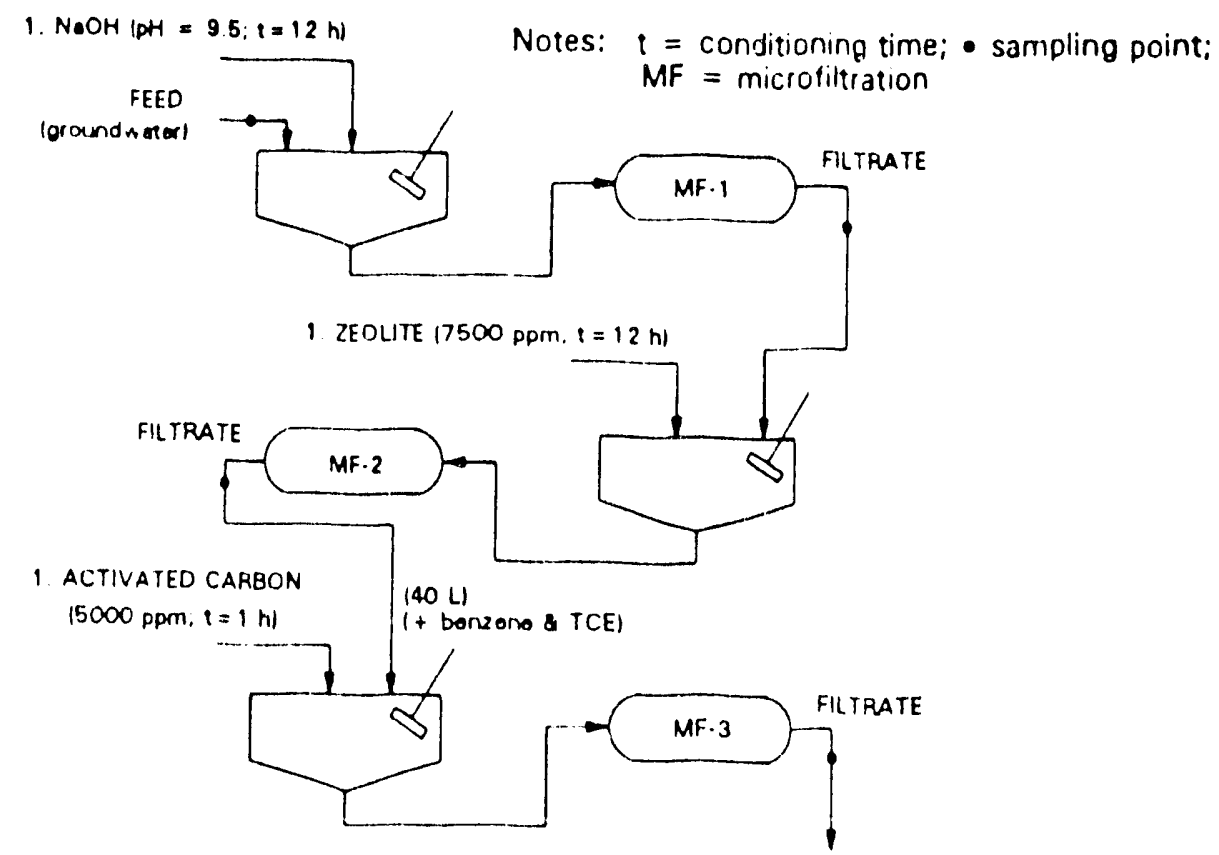


Table C.6: Strontium.90 Removal from Soil-Leachale generated by $0.015 \mathrm{M} \mathrm{FeCl}_{3}$ Leaching of Contaminaled Soil Uaing a Five-Stage Chemical TreatmentMicrofiltration Process (Tea No. 18E.1**)

\begin{tabular}{|c|c|c|c|c|c|}
\hline \multirow[t]{2}{*}{ Purameter/Sircam Deacription } & \multicolumn{3}{|c|}{ Slage No. } & \multirow[b]{2}{*}{ MF-4 } & \multirow[b]{2}{*}{ MF.5 } \\
\hline & MF-1 & MF-2 & MF-3 & & \\
\hline $\begin{array}{l}\text { Feed concentration }(\mathrm{Sr}-90 \mathrm{~Bq} / \mathrm{L})^{*} \\
(2 n)\end{array}$ & $\begin{array}{l}15700 \\
(1533)\end{array}$ & - & 2700 & 880 & 170 \\
\hline Feed water quality Index (FWQD) & 44857 & $\cdots$ & 7714 & 2514 & 485 \\
\hline $\begin{array}{l}\text { Filtuate conc. (Sr-90 Bq/L) } \\
\text { Cummulative } 8 \mathrm{Sr}-90 \text { removal } \\
\text { Filtute Quality index (PWQI) }\end{array}$ & $\overline{-}$ & $\begin{array}{l}2700 \\
82.8 \\
7714\end{array}$ & $\begin{array}{l}1600 \\
94.4 \\
5333\end{array}$ & $\begin{array}{l}170 \\
98.9 \\
486\end{array}$ & $\begin{array}{l}50 \\
99.7 \\
143\end{array}$ \\
\hline
\end{tabular}

Note: The water quality indices FWQI and PWQI are defined as a ratio of contaminant concentration in waste feed $(F)$ or in treated filtrate $(P)$ to the maximum allowable concentration of the contaminant in drinking water under U.S. EPA regulations; 2s: 2 sigma atatistics; - analysis by Y-90 extraction; *- The lest involved caustic soda precipitation at $\mathrm{pH}=9.5$ in the MF-1 atage, followed by zeolite addition (7500 ppm) and conditioning for about $12 \mathrm{~h}$ followed by micrefiltration for each successive stage, MF-2 10 MF.5.

Table C.7: Strontium-90 Removal from Soil-Leachate Aged for about Six Months, Originally Generated by $0.015 \mathrm{M} \mathrm{FeCl}_{3}$ Leaching of Contaminated Soil Using - Four-Stage Chemical Treatment-Microfiltration Process (Test No. 18E.2)

\begin{tabular}{lcccc}
\hline Parameter/Stream Dexcription & \multicolumn{4}{c}{ Siage No. } \\
\cline { 2 - 5 } & MF-1 & MF-2 & MF-3 & MF-4 \\
\hline Feed concentration(Sr-90 Bq/L) & 43156 & 42372 & 6241 & 4769 \\
Feed water quality Index (FWQD) & 123303 & 121062 & 17831 & 13625 \\
& & & & \\
Filtrale conc. (Sr-90 Bq/L) & 42372 & 6241 & 4769 & 3679 \\
Cummulative X Sr-90 removal & 1.8 & 85.5 & 88.9 & 91.5 \\
Filtrate Quality index (PWQD) & 121062 & 17831 & 13625 & 10511 \\
\hline
\end{tabular}

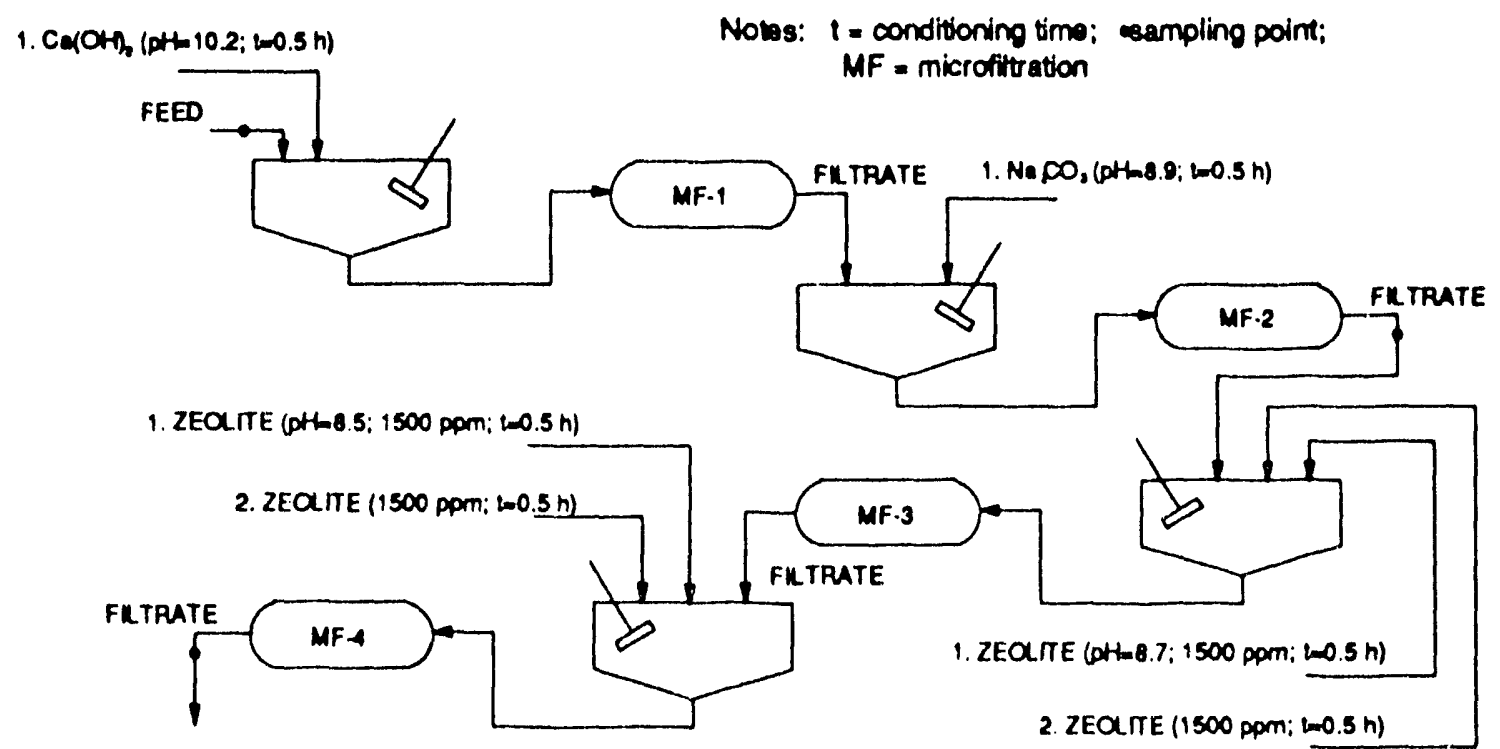


Table C.8: Overall Dewatering Performance with Low-Temperature Evaporation

\begin{tabular}{|c|c|c|c|c|c|c|}
\hline \multirow[t]{2}{*}{ Contaminant } & \multicolumn{2}{|c|}{ Peed } & \multicolumn{2}{|c|}{ Overhead } & \multirow{2}{*}{$\begin{array}{l}\text { Ave. Conc. } \\
\text { Pactor }\end{array}$} & \multirow{2}{*}{$\begin{array}{l}\text { Overhead Water } \\
\text { Quall ty } \\
\text { Index } \\
\text { (PWOI) }\end{array}$} \\
\hline & Ave. Conc. & $\begin{array}{l}\text { Ave. Temp. } \\
\text { Vaporizer } \\
\left({ }^{\circ} \mathrm{C}\right)\end{array}$ & Ave. Conc. & $\begin{array}{l}\text { Ave. Flow } \\
\text { Rate } \\
\text { (L/min) }\end{array}$ & & \\
\hline \multicolumn{7}{|l|}{ Test No. 7B } \\
\hline $\begin{array}{l}\text { Lead } \\
(2 s) \\
\text { Cadmium } \\
(2 s) \\
\text { Iron } \\
(2 s) \\
\text { Uranium } \\
(2 s)\end{array}$ & $\begin{array}{c}94.2 \\
(2.46) \\
22.7 \\
(0.27) \\
478.0 \\
(6.55) \\
4.5 \\
(0.15)\end{array}$ & $6 \pm 0.2$ & $\begin{array}{l}<0.021 \\
<0.002 \\
<0.048 \\
<0.038\end{array}$ & 0.151 & 3 & $\begin{array}{l}<0.42 \\
<0.20 \\
<0.16 \\
<0.63\end{array}$ \\
\hline \multicolumn{7}{|l|}{ Test No. $7 \mathrm{G}$} \\
\hline $\begin{array}{l}\text { Iron } \\
(2 s) \\
\text { Cadmium } \\
(2 s)\end{array}$ & $\begin{array}{l}262.0 \\
(4.03) \\
26.0 \\
(0.3)\end{array}$ & $6.4 \pm 0.2$ & $\begin{array}{c}0.018 \\
(0.002) \\
<0.0018\end{array}$ & 0.116 & 22 & $\begin{array}{l}0.08 \\
(0.009) \\
<0.24\end{array}$ \\
\hline \multicolumn{7}{|l|}{ Test No. 7C } \\
\hline $\begin{array}{l}\text { Cesium-137 } \\
\text { (2s) } \\
\text { Stront Ium-85 } \\
(2 s)\end{array}$ & $\begin{array}{c}57.0 \\
(18.7) \\
60.0 \\
(34.6)\end{array}$ & $8.3 \pm 0.3$ & $\begin{array}{l}<3 \mathrm{~Bq} / \mathrm{L} \\
<4 \mathrm{~Bq} / \mathrm{L}\end{array}$ & 0.13 & 11.3 & $\begin{array}{l}<0.81 \\
<0.03\end{array}$ \\
\hline \multicolumn{7}{|l|}{ Test No. 7D } \\
\hline $\begin{array}{l}\text { Benzene } \\
(2 s) \\
\text { TCE } \\
(2 s)\end{array}$ & $\begin{array}{c}0.0079 \star \\
(0.0007) \\
0.0072 \star \\
(0.0003)\end{array}$ & $5.9 \pm 0.1$ & $\begin{array}{r}0.155 \star \star \\
(0.0098) \\
0.095 \star \star \\
(0.0004)\end{array}$ & 0.104 & & \\
\hline \multicolumn{7}{|l|}{ Test No. 13.1} \\
\hline $\begin{array}{l}\text { Strontium-90 } \\
\text { (2s) } \\
\text { Iron } \\
\text { (2s) } \\
\text { Calcium } \\
(2 s)\end{array}$ & $\begin{array}{c}8.0 \\
(2.94) \\
139.0 \\
(2.42) \\
292 \\
(5.93)\end{array}$ & $5.9 \pm 0.1$ & $\begin{array}{l}<0.8 \mathrm{~Bq} / \mathrm{L} \\
0.006 \\
(0.0007) \\
0.005 \\
(0.0006)\end{array}$ & 0.166 & 24.0 & $\begin{array}{l}<2.3 \\
0.02 \\
(0.0023) \\
3 \times 10^{-5} \\
3.6 \times 10^{-7}\end{array}$ \\
\hline
\end{tabular}

Note:

* Inftial concentration in the supernatant

** Over a period of 130 min of evaporation, concentration of organics in the overhead increased gradually with evaporation time showing stripping and volatilization effects. 
Table C.9: Sumary of Dewatering Test Results Using Pilter Press

Feed Composition

Test No.
Concentration (mg/L)

Zeolite Iron Cadmium Lead

Precipitant pH Volume

\begin{tabular}{|c|c|c|c|c|c|c|c|}
\hline 1 & 20000 & $\cdots$ & --- & --- & $-\cdots$ & 6.7 & 35 \\
\hline $\begin{array}{l}2 \star \\
(2 s)\end{array}$ & 20000 & $\begin{array}{l}3800 \\
(34.9)\end{array}$ & --- & $-\cdots$ & $\mathrm{NaOH}$ & 10.7 & 30 \\
\hline $\begin{array}{c}3 \\
(2 s)\end{array}$ & 20000 & $\begin{array}{l}1000 \\
(11.8)\end{array}$ & $\cdots$ & $-\cdots$ & $\mathrm{NaOH}$ & 10.6 & 30 \\
\hline $\begin{array}{c}4 \\
(2 s)\end{array}$ & 20000 & $\begin{array}{c}979 \\
(11.7)\end{array}$ & $\begin{array}{l}36.4 \\
(0.4)\end{array}$ & $\begin{array}{c}194 \\
(4.9)\end{array}$ & $\mathrm{NaOH}$ & 10.0 & 30 \\
\hline $\begin{array}{c}5 \\
(2 s)\end{array}$ & 20000 & $\begin{array}{l}926 \\
(11.2)\end{array}$ & $\begin{array}{l}35.4 \\
(.4)\end{array}$ & $\begin{array}{l}190 \\
(4.8)\end{array}$ & $\mathrm{Ca}(\mathrm{OH})_{2}$ & 10.2 & 30 \\
\hline
\end{tabular}

Note: * slurry containing $\mathrm{Fe}(\mathrm{OH})_{3}$ was aged for 2 months prior to mixing with zeollte powder (ave. diameter: $44 \mu \mathrm{m}$ )

Piltrate Quality and Dry Weight of Filter Cake

\begin{tabular}{|c|c|c|c|c|c|c|c|c|}
\hline \multirow[t]{2}{*}{$\begin{array}{l}\text { Test No.l } \\
\text { Stream }\end{array}$} & \multirow[b]{2}{*}{ Iron } & \multicolumn{3}{|c|}{ Filtrate } & \multicolumn{2}{|c|}{ PWQI } & \multirow[b]{2}{*}{$\mathrm{Pb}$} & \multirow{2}{*}{$\begin{array}{l}\text { Pilter Cake } \\
\text { (\% dry wt.) }\end{array}$} \\
\hline & & Cadmium & Lead & Solids & $\mathrm{Fe}$ & $\mathrm{Cd}$ & & \\
\hline 1 & -- & -- & $\cdots$ & 50 & -- & -- & -- & 40.5 \\
\hline 2 & -- & -- & -- & 9 & -- & -- & -- & 39.1 \\
\hline 3 & -- & - & -- & 15 & -- & -- & -- & 30.3 \\
\hline $\begin{array}{c}4 \\
(2 s) \\
4 \star \\
(2 s) \\
5 \\
(2 s) \\
5 * \\
(2 s)\end{array}$ & $\begin{array}{c}0.594 \\
(0.03) \\
0.01, \\
(0.001) \\
0.592 \\
(0.029) \\
<0.0023\end{array}$ & $\begin{array}{l}0.140 \\
(0.005) \\
0.141 \\
(0.005) \\
0.021 \\
(0.001) \\
0.013 \\
(0.005)\end{array}$ & $\begin{array}{c}0.164 \\
(0.005) \\
0.021 \\
\left(7 \times 10^{-4}\right) \\
0.099 \\
(0.003) \\
(0.021\end{array}$ & -- & $\begin{array}{l}1.98 \\
(0.1) \\
0.047 \\
(0.003) \\
1.97 \\
(0.097) \\
<0.008\end{array}$ & $\begin{array}{c}14 \\
(0.5) \\
14.1 \\
(0.5) \\
2.1 \\
(0.1) \\
1.3 \\
(0.5)\end{array}$ & $\begin{array}{l}3.28 \\
(0.1) \\
0.42 \\
(0.014) \\
1.98 \\
(0.06) \\
<0.42\end{array}$ & $\begin{array}{c}39.5 \\
--\end{array}$ \\
\hline
\end{tabular}

Note: * Filtrate from the filter press was filtered through a $0.2 \mu \mathrm{m}$ microfilter. Operating Parameters: Load Cycle: $72-74$ psig; Flush Cycle: 53-60 psig; Module Pressure: 40-45 psig; Load Time: 1 min; Processing Time: $\sim 1$ L/min 

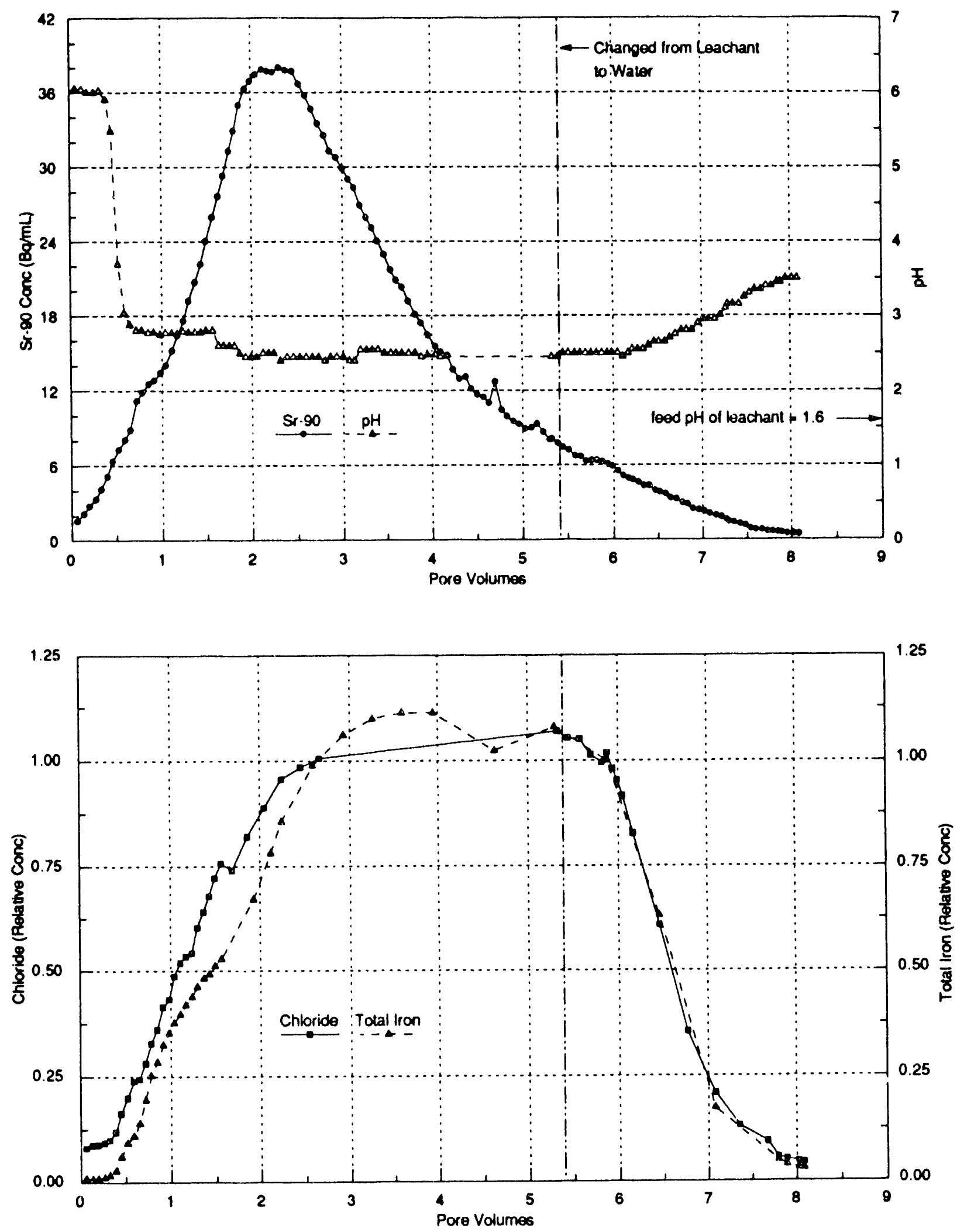

Figure C.1: Profiles for Sr-90, Solution pH, Chloride \& Iron on PilotScale Contaminated Soil Leaching Test 


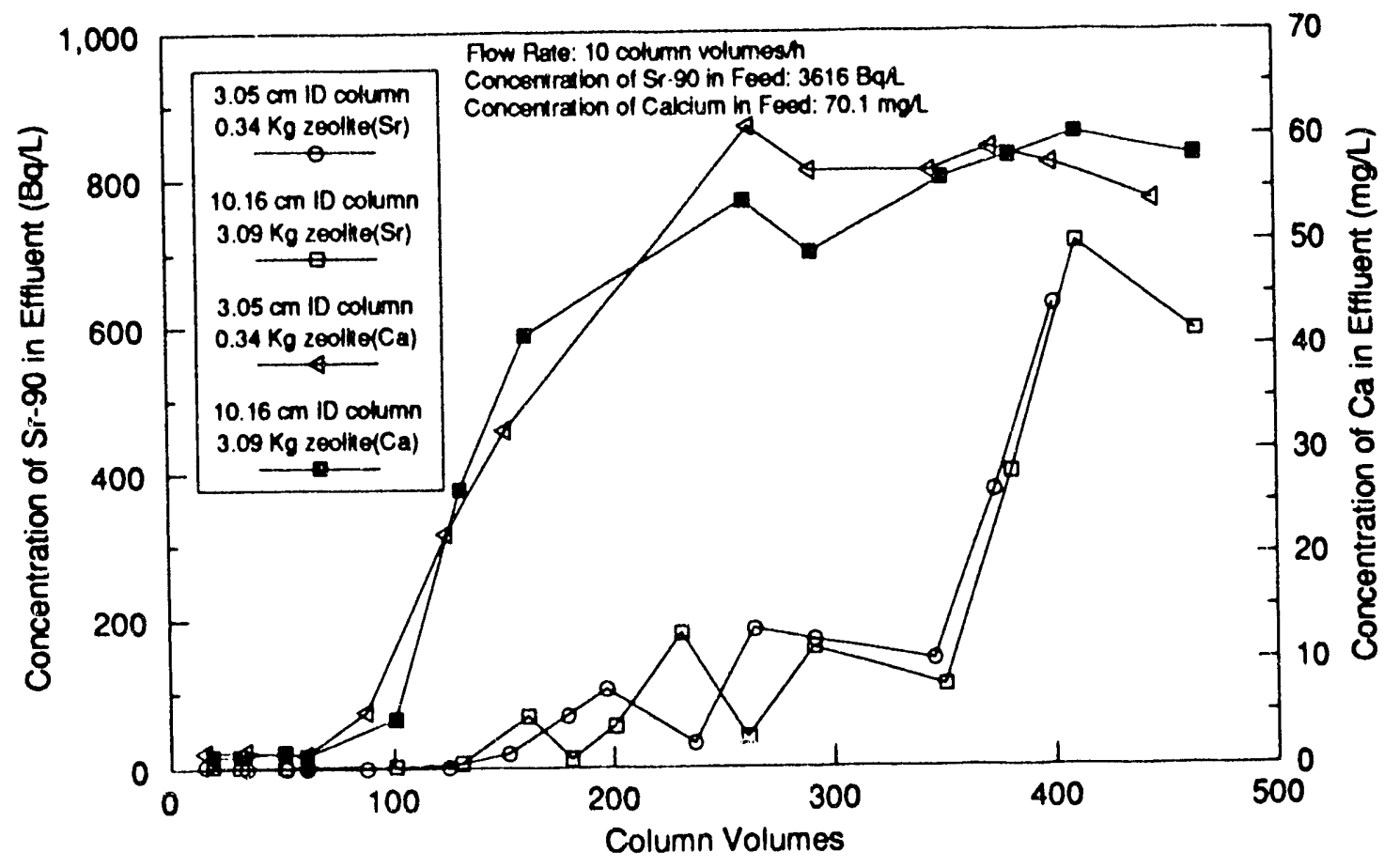

Figure C.2: Profiles of Concentration of $\mathrm{Sr}-90$ and Calcium in Effluent for the Fixed-Bed Column Tests

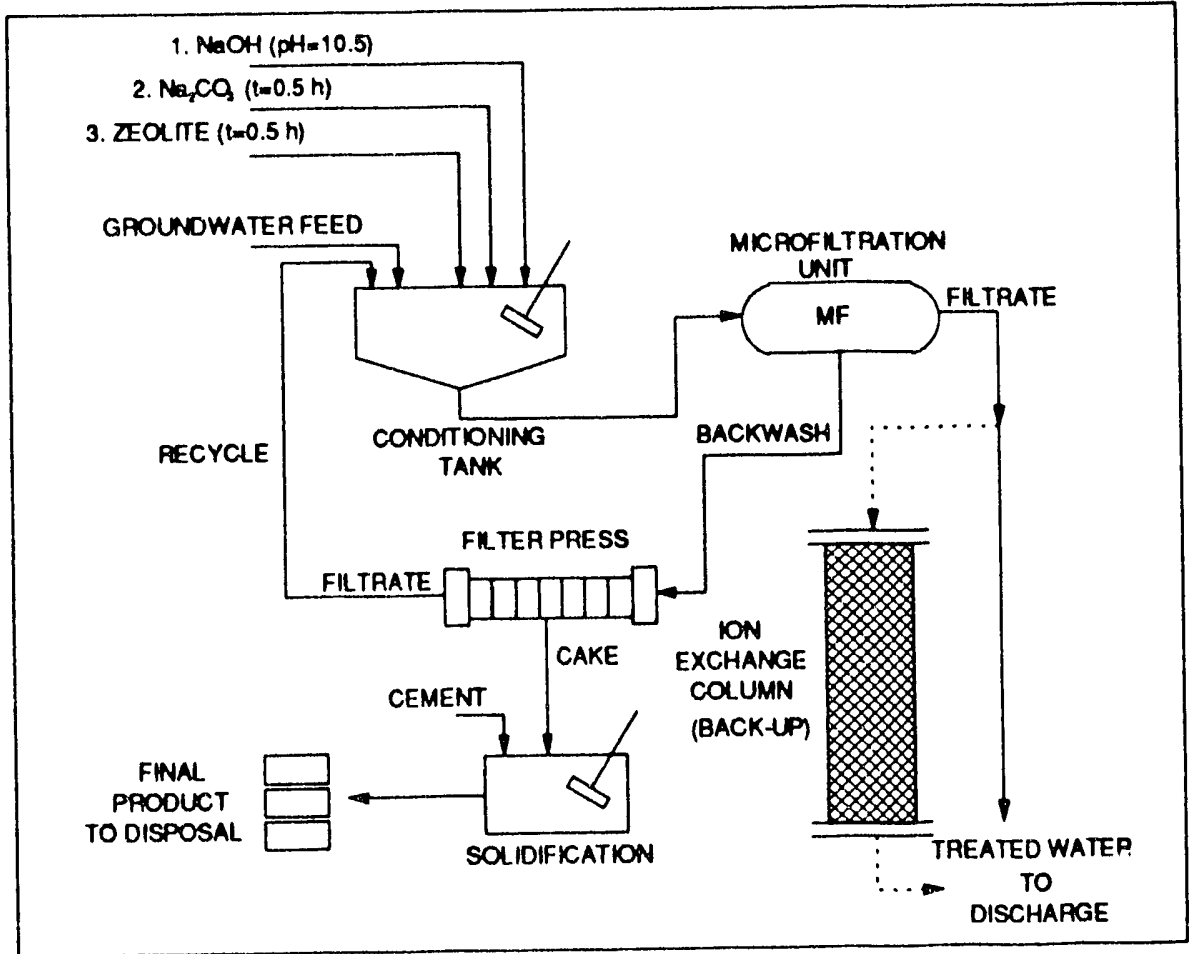

Figure C.3: A Schematic of the Groundwater Treatment Process 
APPENDIX D - PROCESS CONFIGURATION AND COSTS

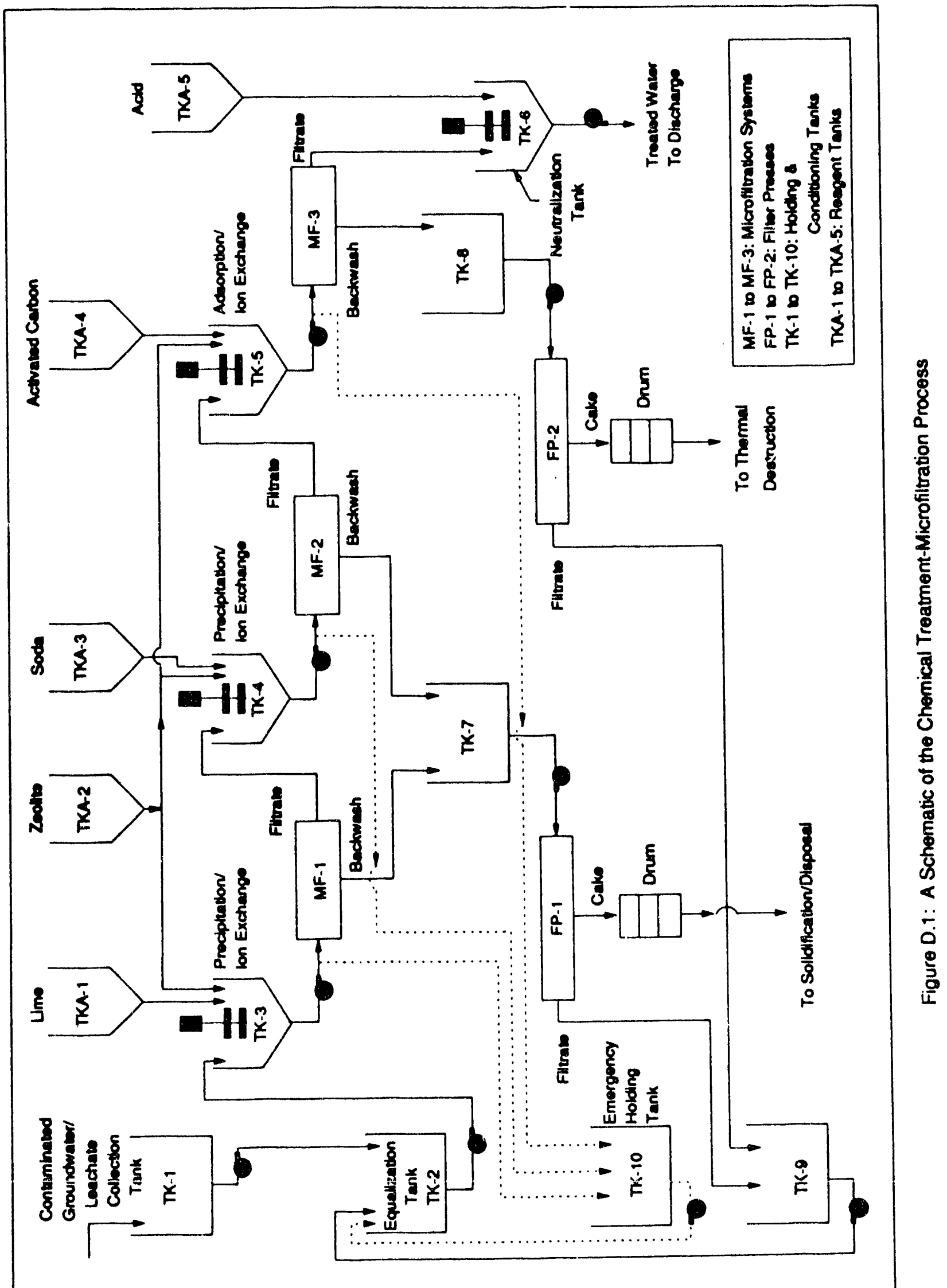




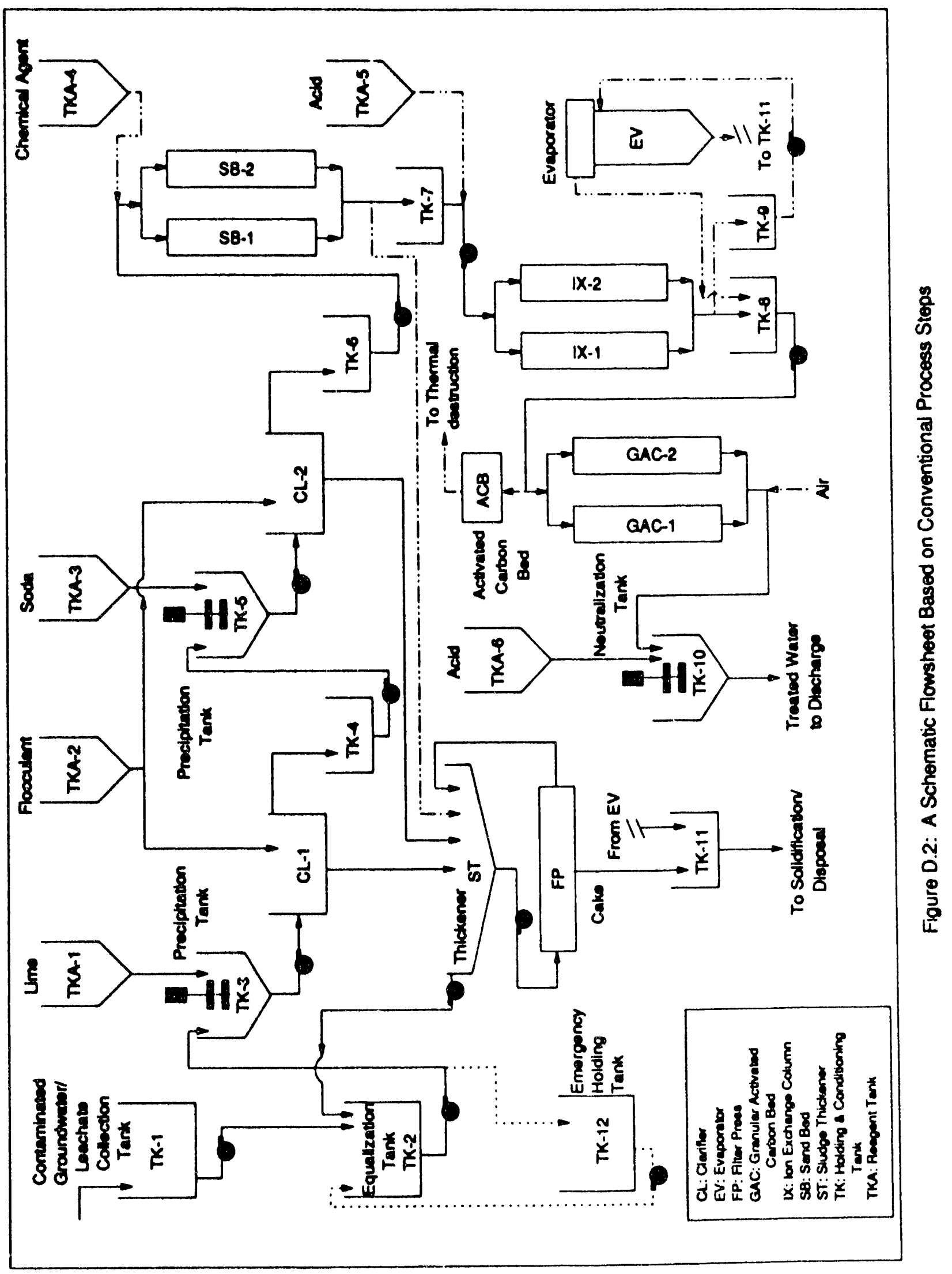


Table D.1: Summary of Mass Balance Calculations for 2 gpm Plant

\begin{tabular}{|c|c|c|c|c|c|}
\hline $\begin{array}{l}\text { Process } \\
\text { Stream }\end{array}$ & $\begin{array}{c}\text { Mass Rate } \\
(\mathrm{kg} / \mathrm{h})\end{array}$ & $\begin{array}{c}\text { Total Solids } \\
\text { TS } \\
(\mathrm{mg} / \mathrm{kg})\end{array}$ & $\begin{array}{l}\text { Total Suspended } \\
\text { Solids, TSS } \\
\text { (mg/kg) }\end{array}$ & $\begin{array}{c}\text { Total Dissolved } \\
\text { Solids, TDS } \\
(\mathrm{mg} / \mathrm{kg})\end{array}$ & $\begin{array}{l}\text { Total Dissolved } \\
\text { Organics, TDO } \\
(\mathrm{mg} / \mathrm{kg})\end{array}$ \\
\hline $\begin{array}{ll}\text { TK1 } & \text { (e) } \\
\text { TK2 } & \text { (e) } \\
\text { TKA1 } & \text { (e) } \\
\text { TKA2 } & \text { (e) } \\
\text { TK3 } & \text { (e) } \\
\text { MP1 } & \text { (f) } \\
\text { MP1 } & \text { (c) } \\
\text { TKA3 } & (\mathrm{e}) \\
\text { TK4 } & \text { (e) } \\
\text { MR2 } & \text { (f) } \\
\text { MP2 } & \text { (c) } \\
\text { TKA4 } & \text { (e) } \\
\text { TK5 } & \text { (e) } \\
\text { MP3 } & \text { (f) } \\
\text { MP3 } & \text { (c) } \\
\text { TKA5 } & \text { (e) } \\
\text { TK6 } & \text { (e) } \\
\text { TK8 } & \text { (e) } \\
\text { FP2 } & \text { (f) } \\
\text { FP2 } & \text { (c) } \\
\text { TK7 } & \text { (e) } \\
\text { FP1 } & \text { (f) } \\
\text { FP1 } & \text { (c) } \\
\text { TK9 } & \text { (e) }\end{array}$ & $\begin{array}{r}396.70 \\
454.32 \\
0.08 \\
1.96 \\
454.85 \\
432.11 \\
22.74 \\
0.17 \\
433.58 \\
411.90 \\
21.68 \\
0.82 \\
412.93 \\
392.28 \\
20.65 \\
6 \times 10.8 \\
392.28 \\
20.65 \\
18.14 \\
2.51 \\
44.42 \\
39.48 \\
4.94 \\
57.62\end{array}$ & $\begin{array}{r}265.5 \\
612.5 \\
541036.7 \\
1000000.0 \\
1708.2 \\
228.5 \\
29822.2 \\
434003.2 \\
3386.9 \\
\\
246.0 \\
63063.8 \\
1000000.0 \\
2 \quad 739.2 \\
\\
232.6 \\
50362.7\end{array}$ & 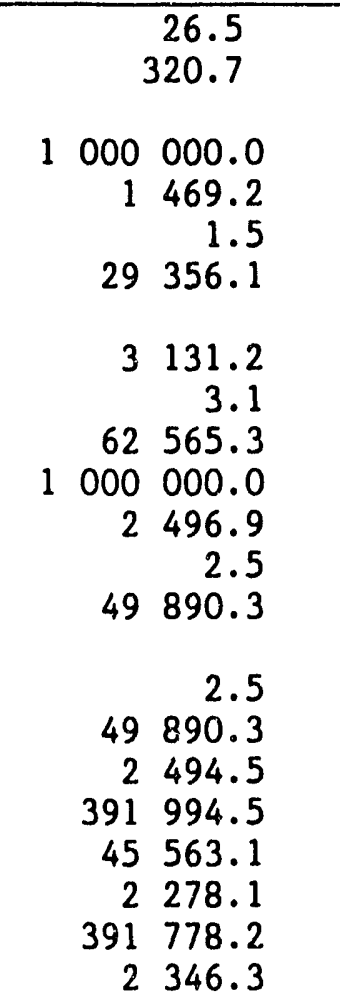 & $\begin{array}{r}239.0 \\
227.0 \\
466.1 \\
434003.2 \\
255.7 \\
242.9 \\
498.5\end{array}$ & $\begin{array}{cc} & 0.02 \\
& 317.9 \\
& 0.3 \\
2 & 610.2 \\
& 216.3 \\
& 108.1 \\
1 & 081.1 \\
& 74.2\end{array}$ \\
\hline
\end{tabular}

\section{Note:}

1) (e) - exiting stream; (f) - filtrate stream; (c) - concentrate stream

2) Total dissolved solids (TDS) account for all dissolved cations in solution.

3) Total solids (TS) = Total suspended solids (TSS) + Total dissolved solids (TDS).

4) Waste Influent Composition used: (concentration of metals and organics in $\mathrm{mg} / \mathrm{L}$ ) $[\mathrm{Cd}]=20 ;[\mathrm{Pb}]=50 ;[\mathrm{U}]=10 ;$ [other heavy metals $]=10 ;[\mathrm{Fe}]=75 ;[\mathrm{Ca}]=50$; $[\mathrm{Na}]=50 ;$ [benzene] $=10 ;$ [trichloroethylene] = 10; [other organics] $=10$; $[\mathrm{Sr}-90]=0.00001 ;[\mathrm{Cs}-137]=0.00001$

5) Chemical Addition (in $\mathrm{mg} / \mathrm{L}$ ): [lime] $=180.5 ;$ [soda] $=391.2 ;$ [zeolite] $=1000$ (step $\# 1), 3000$ (step \#2)\& 500 (step $\$ 3$ ); [powdered carbon] $=2000$.

6) Contaminant Removal Efficiencies $(\%)$ and Volume Reduction Factor (VRF): Process Step 1 (MF1): VRF $=20$; Removal Efficiency: TSS $=99.9 \%$; TDS $=5 \%$; $\mathrm{TDO}=25 \% ; \mathrm{Sr}-90=25 \%$ and $\mathrm{Cs}-137=90 \%$. Process Step $\neq 2$ (MF2): VRF $=20$; Removal Efficiency: TSS $=99.9 \%$; TDS $=5 \%$; $\mathrm{TDO}=40 \% ; \mathrm{Sr}-90=99 \%$ and $\mathrm{Cs}-137=85 \%$. Process Step $* 3$ (MF3): VRF $=20 ;$ Removal Efficiency: TSS $=99.9 \% ;$ TDS $=5 \%$; $\mathrm{TDO}=99.9 \% ; \mathrm{Sr}-90=40 \%$ and $\mathrm{Cs}-137=40 \%$. F11ter Pressing (FP2): [TSS] in concentrate stream 40\% (dry wt.); VRF = 8.2; Removal Efficiency: TSS $=95 \% ;$ TDS $=0.5 \% ;$ TDO $=99.9 \% ; \operatorname{Sr}-90=40 \% ; \mathrm{Cs}-137=40 \%$. Filter Pressing (PP1): [TSS] in concentrate stream $=40 \%$; VRF $=9$; Removal Efficiency: TSS $=95 \% ;$ TDS $=0.5 \% ;$ TDO $=50 \% ;$ Sr $-90=99 \%$ and Cs-137 $=99 \%$. 
Table D.2: A Summary of Estimated Costs for the Proposed 2 gpm Process

Item $\quad$ Description of Cost Category
No.

I Equipment Costs

1. Basic equipment (including tanks, but

140660

excluding building), E

2. Process instrumentation $[0.3 \times \mathrm{E}] \quad 42198$

3. Piping and valves $[0.2 \times \mathrm{E}]$

28132

4. Total Capital Cost of Equipment $[1+2+3+]$, C

210990

II Equipment Installation

5. Installation [0.45 $\times \mathrm{B}$ ]

63297

6. Total Installed Cost $[4+5]$, I

274287

III Basic Annual Operating Costs

7. Labour (2 operators/shift $\mathrm{e} 15 / \mathrm{h}$ and 1 super. a $\$ 25 / \mathrm{h} \& 1$ tech. \& $\$ 15 / \mathrm{h}$ on day shift only)

8. Process energy @ $\$ 0.07 / \mathrm{kWh}[0.035 \times \mathrm{C}]$

9. Analytical $[0.2 \times \mathrm{C}]$

10. Equipment Replacement and repair $[0.03 \times \mathrm{C}]$

11. Chemicals/Reagents (incl. shipment cost of $\$ 110 /$ te)

12. Potable water $@ 2 / 150 \mathrm{gal}$

13. Other consumables $[0.25 \times \mathrm{C}]$

270400

7384

42198

6330

16213

1498

52748

14. Total Basic Operating Cost [items 7 to 13]

396771

IV Aniraal Disposal Costs

15. Destruction by thermal oxidation (e.g. off-site incineration a $\$ 1.5 / \mathrm{kg}$ (15724.8 $\mathrm{kg}$ solid waste)

16. Solidification of $13203.8 \mathrm{~kg}$ solid waste (dry wt.) with equal weight of cement a $\$ 0.25 / \mathrm{kg}$ ]

17. Disposal of $26407.7 \mathrm{~kg}$ cemented waste $\$ 0.5 / \mathrm{kg}$

18. Transportation costs for shipment of sec. waste (42.1 tonnes) e $\$ 110 /$ tonne

19. Shipping/disp. drums (96 x $45 \mathrm{gal}$ drums) @ $\$ 60 /$ drum

23587

3301

13204

4635

5760

20. Total Annual Disposal Cost

50487

V Site Related Costs for Technology Demo or Actual Site Cleanup for 1 year

21. Site preparation [4 $\times$ C]

843961

22. Startup and fixed costs $[0.35 \times \mathrm{C}]$

73847

23. Permitting and Regulatory $[0.048 \times \mathrm{C}]$

24. Effluent monitoring $[0.06 \times \mathrm{C}]$

$\begin{array}{lll}10 & 128\end{array}$

25. Site demobilization $[0.37 \times \mathrm{C}]$

12659

78066

\section{Total Site Related Costs}

1018661

27. Total Annual Operating Cost for Site

1465919 Remediation $[14+20 \div 26]$ 
Table D.3: A Summary of Estimated Costs for the Proposed $300 \mathrm{gpm}$ Process

$\begin{array}{cc}\text { Item Description of Cost Category } & \text { Estimated Cost } \\ & \text { (1991 40 US S) }\end{array}$

No. (1991 40 US \$)

I Equipment Costs

1. Basic equipment (including tanks, but

2034739

excluding building), $\mathrm{B}$

2. Process instrumentation $[0.3 \times \mathrm{E}]$

610422

406948

4. Total Capital Cost of Equipment $[1+2+3+]$, C

3052109

II Equipment Installation

5. Installation $[0.45 \times \mathrm{E}]$

6. Total Installed Cost $[4+5]$, I

915633

3967742

III Basic Annual Operating Costs

7. Labour (4 operators/shift @\$15/h; $1 \mathrm{mgr}$. @ $\$ 30 / \mathrm{h} ; \quad 648960$

1 supervisore $\$ 25 / \mathrm{h}$ \& 1 tech. \& $\$ 15 / \mathrm{h}$ and $1 \mathrm{sec}$.

e $\$ 12.75 / \mathrm{h}$ on day shift only)

8. Process energy o $\$ 0.07 / \mathrm{kWh}[0.035 \times \mathrm{C}]$

9. Analytical $[0.2 \times \mathrm{C}]$

10. Equipment Replacement and repair $[0.03 \times \mathrm{C}]$

11. Chemicals/Reagents (incl. shipment cost of $\$ 110 /$ te)

12. Potable water $@ 2 / 150 \mathrm{gal}$ for $1000 \mathrm{gal}$ waste processed

13. Other consumables $[0.05 \times \mathrm{C}]$

106824

610422

91563

2276584

224640

152605

\section{Total Basic Operating Cost [items 7 to 13]}

IV Annul Disposal Costs

15. Destruction by thermal oxidation (e.g. offsite incineration @ $\$ 1500 /$ te (2359.968 te)

16. Solidification of 2328.3 te solid waste (dry wt.) with equal weight of cement @ $\$ 250 /$ te $(1887.9744$ te)

17. Disposal of 7016.56 te cemented waste e $\$ 500 /$ te

18. Transportation costs for shipment of sec. vaste ( 7016.56 tonnes) \& $\$ 110 /$ tonne

19. Shipping drums (15947 x 45 gal drums) e $\$ 60 /$ drum

20. Total Annual Disposal Cost

3539952

582067

2328269

771816

956820

8178924

V Annual Site Related Costs for Actual Cleanup

21. Site preparation $[4 \times \mathrm{C}]$

22. Startup and fixed costs $[0.35 \times \mathrm{C}]$

23. Permitting and Regulatory $[0.048 \times \mathrm{C}]$

24. Effluent monitoring $[0.06 \times \mathrm{C}]$

25. Site demobilization $[0.37 \times \mathrm{C}]$

12208436

1068238

146501

$\begin{array}{lll}183 & 127\end{array}$

1129280

26. Total Site Related Costs

14735582

27. Total Annual Operating Cost for Site

27026104 Remediation $[14+20+26]$ 
Internal:

J. E. Battles

N. J. Beskid

S. K. Bhattacharyya

A. S. Boparai

S. S. Borys

D. E. Bugielski

J. Burton

D. J. Chaiko

S. M. Cross

J. C. Cunnane
J. S. Devgun

J. D. Ditmars

D. E. Edgar

M. D. Erickson

N. L. Goetz

J. E. Helt

D. O. Johnson

R. Kolpa

T. R. Krause
J. Laidler R. Martello N. K. Meshkov PCO Office (50)
A. D. Pflug
G. T. Reedy
N. F. Sather
M. Zielke
TIS Files

\section{External:}

DOE-OSTI (2)

ANL-E Library (2)

ANL-W Library

Manager, Chicago Field Office, DOE
A. Bindokas, DOE-CH
J. C. Haugen, DOE-CH

S. L. Webster, DOE-CH

A. H. Aitken, Nuclear Diagnostic Systems, Inc., Springfield, VA

D. H. Alexander, USDOE, Office of Technology Development, Washington, DC

J. Allison, USDOE, Office of Waste Operations, Washington, DC

T. D. Anderson, USDOE, Office of Technology Development, Washington, DC

M. S. Anderson, Ames Laboratory, Iowa State University, Ames, IA

G. Andrews, EG\&G Idaho, Idaho Falls, ID

R. W. Baker, Membrane 'Technology \& Research, Inc., Menlo Park, CA

D. H. Bandy, USDOE, Albuquerque Operations Office, Albuquerque, NM

M. J. Barai. ‘a, USDOE, Office of Technology Development, Washington, DC

S. Bath, Wesunghouse Hanford Company, Richland, WA

S. A. Batterman, University of Michigan, Ann Arbor, MI

J. Baublitz, USDOE, Office of Environmental Restoration, Washington, DC

J. Bauer, USDOE, Office of Environmental Restoration, Washington, DC

B. G. Beck, Coleman Research Corporation, Fairfax, VA

R. C. Bedick, USDOE, Morgantown Energy Technology Center, Morgantown, WV

M. Berger, Los Alamos National Laboratory, Los Alamos, NM (5)

J. D. Berger, Westinghouse Hanford Company, Richland, WA (5)

D. Berry, Sandia National Laboratories, Albuquerque, NM (5)

D. Biancosino, USDOE, Office of Technology Development, Washington, DC

J. Bickel, USDOE, Albuquerque Operations Office, Albuquerque, NM

T. Blayden, STC Library, Westinghouse Electric Corp., Pittsburgh, PA

W. Bliss, Reynolds Electric \& Engineering Co., Las Vegas, NV (5)

L. C. Borduin, Los Alamos National Laboratory, Los Alamos, NM

D. Bottrell, USDOE, Office of Technology Development, Washington, DC

G. G. Boyd, USDOE, Office of Technology Development, Washington, DC

I. L. Bratton, Applied Research Associates, Inc., Albuquerque, NM 
J. Buelt, Battelle Pacific Northwest Laboratory, Richland, WA

J. Bursell, EIC Laboratories, Norwood, MA

W. Buttner, Transducer Rescarch, Naperville, IL

J. W. Cammann, Westinghouse Hanford Company, Richland, WA

M. M. Carrabba, EIC Laboratories, Inc., Norwood, MA

R. A. Carrington, Mountain States Energy, Inc., Butte, MT (5)

M. Carter, USDOE, Laboratory Management Division, Germantown, MD

K. A. Chacey, USDOE, Office of Waste Operations, Washington, DC

J. C. Clark, Bay Geophysical Assoc., Traverse City, MI

J. Collins, Colcman Research Corporation, Columbia, MD

P. Colombo, Brookhaven National Laboratories, Upton, NY (5)

D. Constant, South/Southwest HSRC, Louisianna State University, Baton Rouge, LA

S. Conway, Colorado Center for Environmental Management, Golden, CO (5)

J. Corones, Ames Laboratory, Iowa State University, Ames, IA (5)

S. P. Cowan, USDOE, Office of Waste Operations, Washington, DC

R. B. Craig, Hazardous Waste Remedial Actions Program, Oak Ridge, TN

D. Daffern, Reynolds Electrical \& Engineering Company, Las Vegas, NV

W. Daily, Lawrence Livermore National Laboratory, Livermore, CA

R. C. Doyle, IIT Research Institute, Virginia Tech. Center, Newington, VA

L. P. Duffy, USDOE, Environmental Restoration and Waste Management, Washington, DC

H. Dugger, Kaiser Engineers Hanford Company, Richland, WA (5)

A. J. Eirich, Kaiser Engineers Hanford Company, Richland, WA

D. Emilia, Chem-Nuclear Geotech, Grand Junction, CO (5)

B. D. Ensley, Envirogen, Inc., Princeton Research Center, Lawrenceville, NJ

L. Erickson, Center for HSR, Kansas State University, Manhattan, KS

L. Feder, Institute of Gas Technology, Chicago, IL

H. D. Feiler, Science Applications International Corp., Oak Ridge, TN

H. Feiner, Science Applications International Corp., Oak Ridge, TN

J. J. Ficre, USDOE, Office of Environmental Restoration, Washington, DC

W. Fitch, USDOE, Idaho Field Office, Idaho Falls, ID

J. Ford, Hazardous Waste Remedial Action Program, Oak Ridge, TN (5)

A. J. Francis, Brookhaven National Laboratory, Upton, NY

C. Frank, USDOE, Office of Technology Development, Washington, DC

R. B. Gammage, Oak Ridge National Laboratory, Oak Ridge, TN

C. Gehrs, Oak Ridge National Laboratory, Oak Ridge, TN

J. F. Gibbons, Applied Research Associates, Albuquerque, NM

R. Gilchrist, Westinghouse Hanford Company, Richland, WA (5)

B. Gillies, Energy Technology Engineering Center, Canoga Park, CA (5)

G. Glatzmaier, Solar Energy Research Institute, Golden, CO

S. Goforth, Westinghouse Savannah River Company, Aiken, SC

S. R. Grace, USDOE, Rocky Flats Office, Golden, CO

S. Grant, Center for HSR, Kansas State University, Manhattan, KS

T. C. Greengard, Rocky Flats Plant, Golden, CO

W. Greenman, GTS/Duratek Corporation, Columbia, MD

B. Gupta, National Renewable Energy Laboratory, Golden, CO (5)

K. Hain, USDOE, Office of Technology Development, Washington, DC

J. Hall, USDOE, Nevada Field Office, Las Vegas, NV

M. S. Hanson, Battelle Pacific Northwest Laboratories, Richland, WA

L. H. Harmon, USDOE, Office of Waste Operations, Washington, DC

K. A. Hayes, USDOE, Office of Environmental Restoration, Washington, DC 
E. L. Helminski, Weapons Complex Monitor, Washington, DC

J. M. Hennig, USDOE, Richland Operations Office, Richland, WA

R. Hill, U.S. Environmental Protection Agency, Cincinnati, $\mathrm{OH}$

J. Holm, USDOE, Office of Technology Development, Washington, DC

W. Holman, USDOE, San Francisco Operations Office, Oakland, CA

J. P. Hopper, Westinghouse Materials Company of Ohio, Cincinnati, $\mathrm{OH}$ (5)

D. Huff, Martin Marietta Energy Systems, Inc., Oak Ridge, TN

J. Hyde, USDOE, Office of Technology Development, Washington, DC

S. James, U.S. Environmental Protection Agency, Cincinnati, OH

S. Janikowski, EG\&G Idaho, Idaho Falls, ID

W. J. Johnson, Paul C. Rizzo Associates, Inc., Monroeville, PA

D. W. Jones, Nuclear Diagnostics Systems, Inc., Brunswick, TN

D. Kabach, Westinghouse Savannah River Company, Aiken, SC

H. D. Kamaruddin, Membrane Technology \& Research, Inc., Menlo Park, CA

J. Kaschemekat, Membrane Technology \& Research, Inc., Menlo Park, CA

C. Keller, Science and Engineering Associates, Inc., Santa Fe, NM

D. Kelsh, USDOE, Office of Technology Development, Washington, DC

D. R. W. Killey, Atomic Energy of Canada Limited, Ontario, CANADA

J. Kitchens, IIT Research Institute, Newington, VA

J. Koger, Martin Marietta Energy Systems, Oak Ridge, TN (5)

E. Koglin, U.S. Environmental Protection Agency, Las Vegas, NV

K. Koller, EG\&G Idaho, Idaho Falls, ID (5)

G. Kosinski, Technics Development Corporation, Oak Ridge, TN

D. R. Kozlowski, USDOE, Office of Environmental Restoration, Washington, DC

R. Kuhl, EG\&G Idaho, Idaho Falls, ID

J. Lankford, USDOE, Office of Technology Development, Washington, DC

J. C. Lehr, USDOE, Office of Environmental Restoration, Washington, DC

R. Levine, USDOE, Office of Technology Development, Washington, DC

S. C. Lien, USDOE, Office of Technology Development, Washington, DC

R. G. Lightner, USDOE, Office of Environmental Restoration, Washington, DC

D. Lillian, USDOE, Office of Technology Development, Washington, DC

E. Lindgren, Sandia National Laboratory, Albuquerque, NM

B. Looney, Westinghouse Savannah River Company, Aiken, SC

W. Lowry, Science and Engineering Associates, Inc., Santa Fe, NM

P. Lurk, USDOE, Office of Technology Development, Washington, DC

R. W. Lynch, Sandia National Laboratories, Albuquerque, NM (5)

J. E. Lytle, USDOE, Office of Waste Management, Washington, DC

R. S. Magee, New Jersey Inst. Technol., Hazardous Substance Research Center, Newark, NJ

K. Magrini, Solar Energy Research Insitute, Golden, CO

A. Malinauskas, Oak Ridge National Laboratory, Oak Ridge, TN (5)

S. A. Mann, USDOE, Office of Environmental Restoration, Washington, DC

D. Manty, Exploratory Research, U.S. Environ. Protection Agency, Washington, DC

J. Marchetti, USDOE, Defense Programs, Washington, DC

R. G. McCain, Westinghouse Hanford Company, Richland, WA

P. L. McCarty, Hazardous Substance Research Center, Stanford University, Stanford, CA

L. W. McClure, Westinghouse Idaho Nuclear Company, Inc., Idaho Falls, ID (5)

T. McEvilly, Lawrence Berkeley Laboratory, Berkeley, CA (5)

C. P. McGinnis, Oak Ridge National Laboratory, Oak Ridge, TN

K. Merrill, EG\&G Idaho, Idaho Falls, ID (5)

D. J. Moak, Westinghouse Hanford Company, Richland, WA 
J. Moore, USDOE, Oak Ridge Field Office, Oak Ridge, TN

K. Morehouse, Exploratory Research, U.S. Environ. Protection Agency, Washington, DC

H. D. Murphy, Los Alamos National Laboratory, Los Alamos, NM (5)

C. Myler, West Point Chemistry Department, West Point, NY

B. Nielsen, Tyndall Air Force Base, Tyndall Air Force Base, FL

R. Nimmo, IIT Research Institute, Newington, VA

K. Nuhfer, Westinghouse Materials Company of Ohio, Cincinnati, OH (5)

M. O'Rear, USDOE, Savannah River Field Office, Aiken, SC

R. Olexsi, U.S. Environmental Protection Agency, Cincinnati, $\mathrm{OH}$

R. P. Olsen, Membrane Technology \& Research, Inc., Menlo Park, CA

T. Oppelt, U.S. Environmental Protection Agency, Cincinnati, OH

D. F. Oren, Geotech, Inc., Grand Junction, CO

V. M. Oversby, Lawrence Livermore National Laboratory, Livermore, CA

J. Paladino, USDOE, Office of Technology Development, Washington, DC

S. Pamukcu, Lehigh University, Bethlehem, PA

G. S. Patton, USDOE, Office of Technology Development, Washington, DC

I. L. Pegg, Duratek Corp., Columbia, MD

C. Peters, Nuclear Diagnostics Systems, Inc., Springfield, VA

M. Peterson, Battelle Pacific Northwest Laboratory, Richland, WA

J. Poppiti, USDOE, Office of Technology Development, Washington, DC

E. J. Poziomek, University of Nevada, Las Vegas, NV

S. Prestwich, USDOE, Office of Technology Development, Washington, DC

R. E. Prince, Duratek Corporation, Columbia, MD

R. F. Probstein, Massachusetts Institute of Technology, Cambridge, MA

C. Purdy, USDOE, Office of Technology Development, Washington, DC

R. S. Ramsey, Oak Ridge National Laboratory, Oak Ridge, TN

N. Rankin, Savannah River Technology Center, Aiken, SC

C. Rivard, Solar Energy Research Institute, Golden, CO

R. Rizzo, Paul C. Rizzo Associates, Inc., Monroeville, PA

A. Robbat, Tufts University, Medford, MA

W. Robson, Lawrence Livermore National Laboratory, Livermore, CA

L. Rogers, EG\&G Energy Measurements, Inc., Las Vegas, NV (5)

V. J. Rohey, Westinghouse Hanford Co., Richland, WA

M. E. Rose, Membrane Technology \& Research, Inc., Menlo Park, CA

B. Ross, Science and Engineering Associates, Albuquerque, NM

N. E. Rothermich, Hazardous Waste Remedial Actions Program, Oak Ridge, TN

G. Sandness, Pacific Northwest Laboratory, Richland, WA

G. Sandquist, University of Utah, Salt Lake City, UT

P. A. Saxman, USDOE, Albuquerque Operations Office, Albuquerque, NM

W. C. Schutte, USDOE, Office of Technology Development, Washington, DC

K. Schwitzgebel, Sizemore Technical Services, Round Rock, TX

J. A. Scroppo, Blandon International, Inc., Des Plaines, IL

S. V. Segelke, Membrane Technology \& Research, Inc., Menlo Park, CA

M. W. Shupe, USDOE, Office of Technology Development, Washington, DC

J. Simpson, USDOE, Office of Technology Development, Washington, DC

C. Sink, USDOE, Office of Technology Development, Washington, DC

S. C. Slate, Battelle Pacific Northwest Laboratories, Richland, WA (5)

R. Snipes, Hazardous Waste Remedial Actions Program, Oak Ridge, TN

R. Spair, Envirogen, Inc., Lawrenceville, NJ

J. L. Stcele, Westinghouse Savannah River Company, Aiken, SC 
S. Stein, Environmental Management Organization, Seattle, WA (5)

K. Stevenson, USDOE, New York, NY (5)

R. R. Stiger, EG\&G Idaho, Idaho Falls, ID (5)

D. Stoner, EG\&G Idaho, Idaho Falls, ID

A. Tardiff, USDOE, Office of Technology Development, Washington, DC

L. Taylor, USDOE, Office of Environmental Restoration, Washington, DC

L. J. Thibodeaux, South/Southwest HSRC, Louisianna State University, Baton Rouge, LA

J. Tipton, Remote Sensing Laboratory, Las Vegas, NV (5)

E. S. Tucker, Clemson Technical Center, Inc., Anderson, SC

J. A. Turi, USDOE, Office of Waste Operations, Washington, DC

G. P. Turi, USDOE, Office of Environmental Restoration, Washington, DC

R. Tyler, USDOE, Rocky Flats Office, Golden, CO

L. D. Tyler, Sandia National Laboratories, Albuquerque, NM (5)

C. L. Valle, Allied Signal Acrospace, Kansas City, MO (5)

G. E. Voelker, USDOE, Office of Technology Development, Washington, DC

J. W. Wagoner, USDOE, Office of Environmental Restoration, Washington, DC

J. Walker, USDOE, Office of Technology Development, Washington, DC

H. Wang, University of Wisconsin, Madison, WI

R. D. Warner, USDOE, Fernald Field Office, Cincinnati, OH

S. Weber, USDOE, Office of Technology Development, Washington, DC

W. J. Weber, Hazardous Substance Research Center, University of Michigan, Ann Arbor, MI

E. Weiss, Membrane Technology and Research, Inc., Menlo Park, CA

T. Wheelis, Sandia National Laboratories, Albuquerque, NM (5)

M. Whitbeck, University of Nevada, Desert Research Institute, Reno, NV

R. P. Whitficld, USDOE, Office of Environmental Restoration, Washington, DC

P. Wichlacz, EG\&G Idaho, Idaho Falls, ID (5)

C. L. Widrig, Battelle Pacific Northwest Laboratories, Richland, WA

H. Wijmans, Membrane Technology \& Research, Inc., Menlo Park, CA

J. G. Wijmans, Membrane Technology \& Research, Inc., Menlo Park, CA

J. Wilson, Oak Ridge National Laboratory, Oak Ridge, TN

W. Wisenbaker, USDOE, Office of Environmental Restoration, Washington, DC

J. K. Wittle, Electro-Petroleum, Inc., Wayne, PA

S. Wolf, USDOE, Office of Teclinology Development, Washington, DC

T. Wood, EG\&G Idaho, Idaho Falls, ID

J. L. Yow, Livermore, CA (5)

C. Zeh, USDOE, Morgantown Energy Technoloy Center, Morgantown, WV

L. P. Buckley, Atomic Energy of Canada Limited, Ontario, CANADA (10)

D. R. W. Killey, Atomic Energy of Canada Limited, Ontario, CANADA

L. A. Moschuk, Atomic Energy of Canada Limited, Ontario, CANADA

T. M. Thompson, Atomic Energy of Canada Limited, Ontario, CANADA

S. Vijayan, Atomic Energy of Canada Limited, Ontario, CANADA

P. C. F. Wong, Atomic Energy of Canada Limited, Ontario, CANADA 

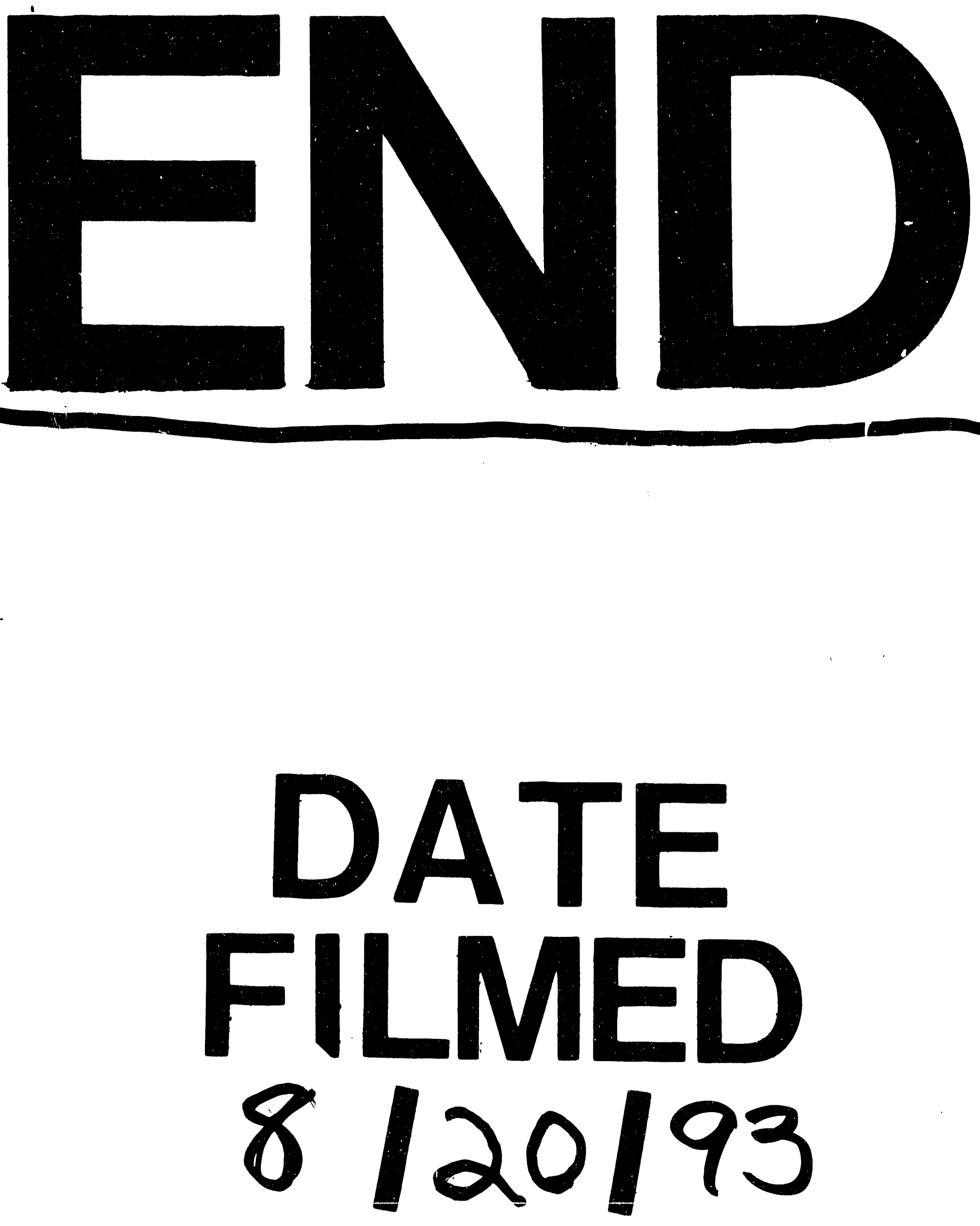